DANMARKS GEOLOGISKE UNDERSøGELSE

III. RAEKKE. NR. 32

GEOLOGICAL SURVEY OF DENMARK. III. SERIES. NO. 32

\title{
Geoelektriske Undersøgelser i Danmark og Skåne 1953
}

\author{
Af \\ Theodor Sorgenfrei \\ English Summary: \\ Geo-electric Surveys \\ in Denmark and Scania 1953
}

I Kommission hos

C. A. REITZELS FORLAG (AXEL SANDAL)

KØBENHAVN 1955 
Med 3 tavler

With 3 plates 
DANMARKS GEOLOGISKE UNDERSØGELSE III. RAKKE. NR. 32

Geological Survey of Denmark. III. Series. No. 32

\title{
Geoelektriske Undersøgelser i Danmark og Skåne 1953
}

\author{
Af \\ Theodor Sorgenfrei \\ English Summary: \\ Geo-electric Surveys \\ in Denmark and Scania 1953
}

I Kommission hos

C. A. REITZELS FORLAG (AXEL SANDAL)

KØBENHAVN 1955 
Med 3 tavler

With 3 plates 


\section{F O R O R D}

Geoelektriske metoder har i udlandet været anvendt som hjælpemiddel ved rent videnskabelige og navnlig praktisk geologiske undersøgelser i en lang årrække. Årsagerne til, at de så forholdsvis sent har fundet anvendelse i Danmark er af forskellig art. En råstofefterforskning i videre forstand med sigte på f. eks. malme, som har dannet baggrunden for geoelektriske metoders fremgang i Sverige og andre lande, har af naturlige grunde ikke været aktuel i Danmark, selvom der forbigående er anvendt resistivitetsmålinger i forsøg på at kortlægge brunkulsforekomster og lignende (I. Berthelsen 1940). Ved opsporingen af vandførende lag har geoelektrisk metodik i nogen grad været overflødiggjort, idet man ved D.G.U. i Borearkivets og Kemisk Laboratoriums samlinger af borejournaler, jordprøver og vandanalyser har haft et udgangsmateriale til at stille prognoser om grundvandsforhold og dybgrundens bjergarter $\mathrm{m}$. $\mathrm{v}$.

Af det efterfølgende vil imidlertid også fremgå, at det udstrakte kendskab til landets geologiske forhold, som er resultatet af den løbende behandling af det indkomne materiale fra boringer, er en udmærket baggrund for modstandsmålinger i Danmark, idet navnlig de kvartærgeologiske forhold stiller særlige krav til udarbejdelsen af metodik og fortolkningen af de geofysiske resultater.

Efter at have sat mig ind i resistivitetsmetodens praktiske og teoretiske muligheder i forbindelse med undersøgelsen af objekter under jordoverfladen har jeg i løbet af $1952 \mathrm{og} 1953$ udarbejdet en fremgangsmåde til undersøgelsen af de i geoelektrisk henseende særligt komplicerede geologiske og hydrologiske forhold, som råder i Danmark.

I det følgende beskrives resultaterne af de herefter udførte undersøgelser. Hovedprincipet har i de enkelte tilfælde været fremskaffelsen af et regionalt overblik ved hjælp af en elastisk tilrettelagt linieprofilopmåling $\mathrm{og}$ dernæst opmåling af punktprofiler i påfaldende resistivitetsanomalier for at fa et indtryk af jordmodstandens vertikale variation. Planlægningen af det geofysiske arbejde er sket på grundlag af en forudgående detailleret geologisk analyse af undersøgelsesområderne.

Metodiken er udarbejdet bl. a. med sigte på opsporingen af vandførende lag og med henblik på løsningen af forskellige hydrologiske problemer, som er af væsentlig betydning ved indvinding af grundvand i Danmark. 
Ved fremlæggelsen af undersøgelserne fra 1953 er der grund til at understrege, at de er fremkommet ved en række medarbejderes fællesindsats. De enkeltes arbejdsområder er nævnt side 25. Det er mig en glæde at kunne takke alle for veludført arbejde. Uden at tilsidesætte nogen må jeg fremhæve civilingeniør Per Holm Andersen, som har haft ansvaret for de indledende fundamentale teoretiske og praktiske elektro-tekniske studier, der gik forud for iværksættelsen af undersøgelserne, ligesom han også har udført en stor del af markarbejdet.

Det har været en betydelig støtte for vort arbejde, at chefingeniør H. Hedström, A.B. Elektrisk Malmletning, Stockholm, har vist os den store velvilje at overlade os sine beregningskurver til fortolkningen af punktprofilerne. Jeg vil udtale min bedste tak for dette udtryk for frugtbart samarbejde.

Docent, civilingeniør G. WeiJman-Hane, Chalmers Tekniska Högskola, Göteborg, vil jeg takke for samarbejdet ved undersøgelserne i Skåne og for tilladelsen til i denne afhandling at anvende en række oplysninger om ikke-offentliggjorte boringer.

Professor, dr. techn. H. Lotwrup Knudsen, Danmarks Tekniske Højskole, har kritisk gennemgået den elektrotekniske del af afhandlingen, og professor dr. David H. Frisch, Massachusetts Institute of Technology har læst korrektur på den engelske sammenfatning. Idet jeg takker for de værdifulde rettelser og forslag, som derved er kommet arbejdet til gode, må jeg understrege, at fejl og mangler iøvrigt naturligvis må falde tilbage på mig selv. 


\section{INDHOLD - CONTENTS}

\begin{tabular}{|c|c|c|}
\hline & Side & $\begin{array}{l}\text { English } \\
\text { Summary p }\end{array}$ \\
\hline Abstract. & 7. & \\
\hline 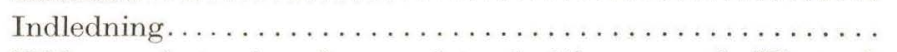 & 8. & \\
\hline Uddrag af teorien for modstandmålinger med Wenner's & & \\
\hline 4-elektrodesystem $\ldots \ldots \ldots \ldots \ldots \ldots \ldots \ldots \ldots \ldots \ldots \ldots$ & 12. & \\
\hline 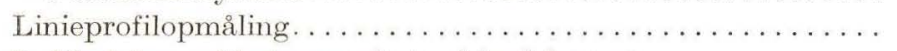 & 19. & \\
\hline Indflydelsen af heterogeniteter i jordskorpen. . . . . . . . . . & 20. & \\
\hline Undersøgelserne i året $1953 \ldots \ldots \ldots \ldots \ldots \ldots \ldots \ldots \ldots \ldots \ldots$ & 23. & 80 \\
\hline Apparatur og operationer i marken . . . . . . . . . . . . . . . . & 23. & \\
\hline 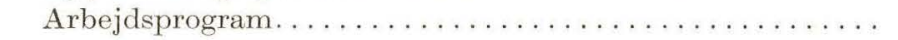 & 24. & \\
\hline 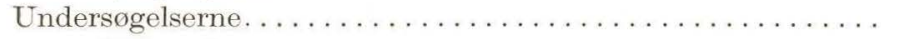 & 26. & 81 \\
\hline 1. Herstedøster. . . . . . . . . . . . . . . . . . . . . . . . . & 26. & 81 \\
\hline 2. Lille Linde, Stevns og Karise................... & 27. & 82 \\
\hline 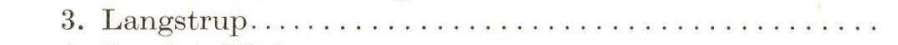 & 34. & 84 \\
\hline 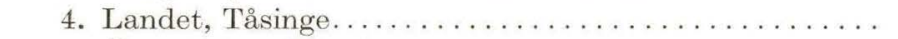 & 40. & 86 \\
\hline 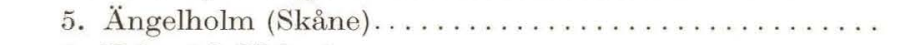 & 44. & 89 \\
\hline 6. Veberöd (Skåne) $\ldots \ldots \ldots \ldots \ldots \ldots \ldots \ldots \ldots \ldots \ldots \ldots \ldots \ldots \ldots$ & 47. & 90 \\
\hline 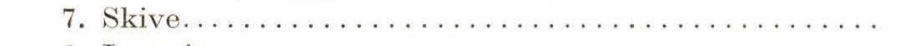 & 51. & 91 \\
\hline 8. Lemvig............................... & 54. & 92 \\
\hline 9. Tåstrup & 56. & 93 \\
\hline 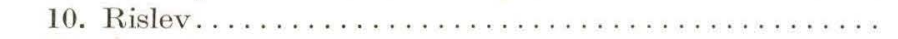 & 60. & 93 \\
\hline 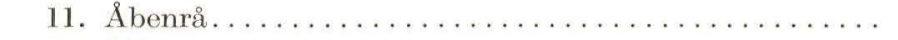 & 65. & 95 \\
\hline 12. Ollerup $\ldots \ldots \ldots \ldots \ldots \ldots \ldots \ldots \ldots \ldots \ldots \ldots \ldots \ldots$ & 68. & 95 \\
\hline 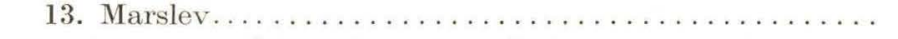 & 74. & 96 \\
\hline Oversigt over undersøgelsernes resultater ............... & 77. & 97 \\
\hline Specifike modstande for en række danske aflejringer....... & 78. & \\
\hline Specific resistivities of some Danish deposits........... & 78. & \\
\hline 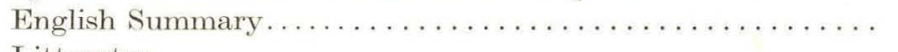 & 79. & \\
\hline 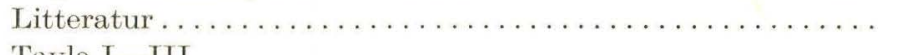 & 98. & \\
\hline
\end{tabular}




\section{ABSTRACT}

The earth resistivity surveys which have been carried out in Denmark and Scania (Southern Sweden) during 1953 in accordance with the WENNER-method include both research and exploration projects.

The particular problem involved in resistivity surveys in Denmark is related to the heterogenous bedding of the Glacial Drift which covers practically the whole country. Level and geologically uniform measuring grounds were therefore selected for particular research projects during the initial stage of the survey in 1953 in order to obtain relatively simple combinations of physical factors in the subsurface.

The final goal of the work was to elaborate a suitable method for mapping of sand and gravel aquifers in the Glacial Drift, bed-rock topography, saltwater occurrences, etc. It was soon realized that a combined method using both trenching measurements and vertical electrical drilling would be the most applicable. Such procedure was applied to fundamental geo-hydrologic problems in different parts of the country after careful geologic planning in each case. The well logs on file in the Well Record Department of the Geological Survey were the very important basis for this work.

The geo-electric work carried out during 1953 has shown that resistivity surveys may yield both scientific and practical results of general value even in a geologically complex region as the Glacial Drift area of Denmark. This is illustrated by 13 case histories of which no. 1, 2, 3, 9, and 10 cover research projects while the rest deals with the location or investigation of aquifers for rural and municipal waterworks. 


\section{INDLEDNING}

Der er i tidens løb udviklet en række fysiske målemetoder, ved hjælp af hvilke man fra jordoverfladen bestemmer størrelsesordenen af forskellige fysiske egenskaber knyttet til jordskorpen. Der er samtidig udfoldet ret store bestræbelser for at føre metoderne frem til stadig større fuldkommenhed. Sådanne bestræbelser er navnlig opmuntret ved, at disse "geofysiske« metoder har fundet en udstrakt anvendelse indenfor den praktiske råstofefterforskning, og at man ved hjælp af dem har opnået en væsentlig nedsættelse af udgifterne ved udførelsen af praktiske geologiske undersøgelser.

Den anvendte geofysik, som navnlig er udarbejdet i tilknytning til mineral- og olieprospektering, omfatter følgende vigtige hovedgrupper:

1. Jordmagnetiske metoder.

2. Tyngdemålingsmetoder.

3. Lydforplantningsmålinger i forbindelse med kunstigt fremkaldte jordskælv.

4. Elektriske metoder.

Ved de jordmagnetiske målinger bestemmes magnetkraftens intensitet $\mathrm{i}$ terrænet på en række stationer, hvis antal og placering er afhængig af den stillede opgave. Da magnetisme navnlig er knyttet til metallisk jern og nikkel samt til magnetjernsten vil det sige, at man ved magnetiske målinger kun i sjældne tilfælde er i stand til at få en påvirkning, der skyldes de lagdelte jordlag. Magnetiske metoder har derfor kun en begrænset anvendelse. Ved hjælp af dem forsøger man især at skaffe sig et overblik over grundfjældets forhold, hvad enten det ligger i stor eller ringe dybde.

Tyngdemålinger udføres efter to eller tre metoder dels som pendulmålinger og dels som direkte tyngdemålinger, ved hjælp af hvilke man bestemmer tyngdekraftens størrelse eller tyngdefeltets intensitet på stationer, hvis antal og placering i terrænet ligesom ved de magnetiske målinger retter sig efter opgavens art. Ved hjælp af såkaldte snovægte foretages mere indirekte målinger af tyngdefeltet, idet man ved dem får et udtryk for tyngdekraftens variation. 
Da alt stof er i besiddelse af masse, omfattes alle jordskorpens lag af tyngdemålinger i modsætning til de magnetiske målinger.

De beregnede resultater, som fremkommer både ved de magnetiske målinger og ved tyngdemålinger, vil oftest blive anskueliggjort ved kortbilleder. Man indfører de beregnede værdier på et kort med de enkelte stationer og trækker kurver igennem punkter med samme intensitet. Derved fremkommer et kurvebillede, som karakteriserer anomalier i området $\mathrm{i}$ forhold til et teoretisk normalfelt. Anomalibilledet bliver derefter fortolket geologisk.

Både ved tyngdekort og kort over magnetkraftens intensitet vil man navnlig kunne opnå at få et overblik over regionale strukturforhold i jordskorpen; derimod er det oftest ugørligt at få en klar forestilling om, hvilke lag der medvirker til at frembringe de lokale afvigelser, for slet ikke at tale om dybden til lagene.

Ved målingerne af lydforplantningen ved kunstige jordskælv udnytter man ekkovirkningen, der er knyttet til grænsefladerne mellem jordlagene, samt brydningen af lydbølgerne langs sådanne lagflader. På en filmstrimmel registreres tidspunktet for eksplosionen, hvorved det kunstige jordskælv frembringes, og tidspunkterne for de efterhånden ankommende lydbølger, som er kastet tilbage fra lagflader i dybet. Det hele afbildes grafisk på millimeterpapir, og man vil ved særlige opstillinger af måleapparaturen i nogen udstrækning kunne bestemme hastigheden for lydbølgerne og dermed også kunne beregne dybder til reflexionsfladerne og refraktionsfladerne.

Ved tilstrækkeligt omfattende studier og sammenligning med kendte geologiske forhold i området vil man herefter kunne danne sig en forholdsvis velbegrundet forestilling både om jordlagenes art, dybde og struktur på grundlag af de seismiske undersøgelser.

De elektriske metoder har været anvendt på forskellige måder til opklaringen af forhold under jordoverfladen. I virkeligheden har disse metoder allerede fundet anvendelse på et forholdsvis tidligt tidspunkt for over hundrede år siden. I modsætning til de førnævnte metoder har geoelektriken navnlig været anvendt i forbindelse med malmefterforskning og i forbindelse med undersøgelsesobjekter relativt nær ved jordoverfladen.

De elektriske metoder kan inddeles på følgende måde:

1. Metoder til udforskning af naturligt forekommende elektriske strømme i jorden.

a. Lokalt optrædende strømme.

b. Telluriske strømme.

2. Metoder i forbindelse med etableringen af kunstige elektriske felter.

a. Ved tilførelse af elektrisk strøm.

b. Ved induktion. 
I forbindelse med malmforekomster optræder elektrokemiske processer, hvorved der i malmkroppe opstår potentialforskelle, som følge af de tilstødende grundvandsniveauers forskellige ionindhold og ionkoncentrationer. Som følge af iltning i forbindelse med grundvandets indvirkning i nærheden af jordoverfladen bliver den øvre del af en malmforekomst således negativ, den nedre positiv, og en elektrisk strøm opstår derfor både i malmlegemet og i de omgivende bjergarter.

Efterforskningsarbejder i forbindelse med sådanne malme går ud på at måle potentialet imellem forskellige punkter på jordoverfladen, hvorved eventuelle malmforekomster vil kunne lokaliseres som negative centrer.

Telluriske strømme er uregelmæssige strømme som optræder regionalt i jorden. De står i nøje relation til variationerne i jordens magnetfelt og iagttages navnlig i tilknytning til de magnetiske forstyrrelser, der betegnes som magnetiske storme. Ved undersøgelsen af de telluriske strømme måles potentialforskellene på forskellige steder. Det har vist sig, at potentialerne, som man måtte vente, er meget afhængige af den elektriske modstand i jordskorpen. Ved kortlægningen af potentialerne har man derfor været i stand til at afgrænse store regionale struktur-enheder eller bjergartsmassiver.

Kunstige elektriske felter frembringes ved, at der sendes en elektrisk strøm ned i jorden ved hjælp af et batteri, en generator eller lignende eller ved induktion. Der foretages herefter målinger af potentialforskellene eller af det elektromagnetiske felt, som frembringes af jordstrømmene.

Inden vi går over til en enkelt af disse målemetoder, som i 1953 har været anvendt af Danmarks Geologiske Undersøgelse vil vi forsøge at danne os et overblik over, hvilken indflydelse jordlagenes egenskaber har eller kan tænkes at have på jordstrømmene.

Betragter man jordlagene, således som de forekommer i naturen, kan man generelt skelne imellem følgende tilstandsformer: fast, flydende og luftformig, repræsenteret ved: 1. de enkelte jordpartikler, 2. porevandet og 3. poreluft (se f. eks. Fritsch 1949).

En elektrisk strøm, som går igennem jordlagene vil gennemløbe en modstand, som er en slags gennemsnitsmodstand for jordpartiklernes, porevandets og jordluftens modstand. Da luften ikke er ledende, er det klart, at jordpartiklernes beskaffenhed og porevandets mængde og sammensætning er afgørende faktorer for ledningsevnen. Oftest er det porevandets sammensætning, som er bestemmende for ledningsevnen. Af ganske væsentlig betydning er naturligvis vandets indhold af opløste stoffer ( $\mathrm{g}$ derved ionkoncentrationen), idet man må gå ud fra, at strømmen i jord- 
lagene for en væsentlig del »bæres« af ionerne i porevandet (elektrolytisk ledning). Jo flere ioner der findes, desto mindre modstand vil strømmen gennemløbe.

Betragter vi forholdene i jordskorpen i store træk, kan man herefter regne med følgende forhold, idet vi først tager hensyn til lagenes vandindhold: Over grundvandspejlet vil man normalt kunne komme ud for lag med mere eller mindre luftfyldte porer med et minimum af vand, hvori modstanden er stor. På forhånd må man vente, at lerlag over grundvandspejlet indeholder mere porevand end sandlag og altså alene af den grund må udvise ringere modstand end sandlag. Under grundvandspejlet vil der teoretisk være en mulighed for, at porevolumen vil indvirke på modstandens størrelse. Som bekendt er porevolumen i sand-og gruslag normalt mindre end i lerlag, vandtværsnittet, som den elektriske strøm gennemløber, vil derfor være mindre i sådanne lag end i ler; m. a. o. ledningsevnen, vil være mindre og modstanden større i sand end i ler, også i grundvandsområdet (se f. eks. Fisch 1946).

Med hensyn til mineralpartiklernes indflydelse på ledningen af den elektriske strøm er det iøvrigt vigtigt at erindre, at man fra et atomfysisk synspunkt skelner mellem følgende tre former for elektrisk ledning: 1. elektronledning, 2. elektrolytisk ledning og 3. dielektrisk ledning: (HeILAND 1951).

Elektronledningen skyldes bevægelsen af frie elektroner og foregår i metalliske ledere og i malmmineraler. Elektrolytisk ledning sker i vædsker, der indeholder ioner, og skyldes transporten af ioner som nævnt ovenfor. Strømretningens skiften i vekselstrømsfelter frembringer forskydninger i mineralernes kerne- og elektronmønstre. Disse udsving forplanter sig gennem partiklerne, hvorved den elektriske strøm ledes. Denne form for ledning kaldes dielektrisk ledning. Når man ser bort fra forskellige malmmineraler, hvori der foregår elektronledning, er mineralerne almindeligvis dårlige ledere. Der er dog grund til at pege på særlige forhold ved lermineralerne.

Som bekendt indeholder ler meget små partikler, der oftest består af mere eller mindre flade og tavleformede mineraler. Man kender en række lermineraler med forskellige egenskaber. Af særlig interesse i denne sammenhæng er lermineralernes såkaldte ionbytningsevne, som ytrer sig ved, at de er i stand til at ombytte kationer, f. eks. natriumioner, med andre kationer f. eks. calciumioner fra omgivende grundvand. (se f. eks. H. ØDUM W. Christensen 1936, p. 38). Denne evne skyldes dels tilstedeværelsen af frie negative ladninger langs mineralkornenes rande, der svarer til iturevne atombindinger, og dels substitution i krystallernes atomgitre. Hos mineralerne kaolinit, halloysit og illit er ionbytningsevnen øjensynlig navnlig knyttet til de frie ladninger medens ionbytningen hos f. eks. montmorillonit og vermiculit tilsyneladende hovedsagelig sker ved substitution (GRIM 1953). 
Ved aftagende partikelstørrelse tiltager antallet af frie ladninger langs randene og dermed ionbytningsevnen. Denne er dog ikke afhængig af partikelstørrelsen alene, idet ionbytningsevnen navnlig er knyttet til lermineralerne. Ionbytningsevnen hos ikke-lermineraler, selv hvor der er tale om små partikelstørrelser, er oftest ubetydelig. Dog har visse zeolitmineraler forholdsvis stor ionbytningsevne (GRIM, l.c.).

En vis mængde af de adsorberende kationer er ioniseret. Mængden er afhængig af mineralet, vandindholdet, koncentrationen af ler-vandsystemet, kationerne i vandet, disses koncentration og arten af de adsorberede ioner.

Da lerlag og skiferlag (der oprindeligt også er dannet som ler) er gode ledere for den elektriske strøm, sammenlignet med andre jordlag, og har tilsvarende lille modstand, er det efter det ovenfor nævnte rimeligt at slutte, at den store ledningsevne bl. a. skyldes lermineralernes ionisering.

\section{Uddrag af teorien for modstandsmålinger med WENNER's 4-elektrodesystem.}

Modstanden $R$ i en leder er ligefrem proportional med lederens længde $l$ og omvendt proportional med tværsnittet $s$ efter formlen:

$$
R=\varrho \cdot \frac{l}{s}
$$

hvor $\varrho$ er en konstarrt, der kaldes for den specifike modstand og afhænger af lederens bestanddele. Den er lig med modstanden mellem to parallele sider i en terning af stoffet med siden $1 \mathrm{~cm}$ og udtrykkes i ohm-centimeter. Da brugen af enheden ohm-centimeter oftest resulterer i høje nummeriske værdier for den specifike modstand anvendes i praksis ved måling af modstanden i jordlagene også enheden ohm-meter, svarende til modstanden af en terning med siden $1 \mathrm{~m}$. Af ovenstående formel følger, at en ohm-meter er lig $100 \mathrm{ohm}$ centimeter.

Et stofs ledningsevne $\sigma$ defineres som den reciproke værdi af $\varrho$ :

$$
\sigma=\frac{1}{\varrho}=\frac{1}{s R}
$$

Teorien for de elektriske jordundersøgelsesmetoder er ret kompliceret. Der findes en omfangsrig litteratur herom. En af de simpleste målemetoder er udarbejdet af WENNER (1915). Ved hjælp af f. eks. en generator med en EMK på nogle hundrede volt etableres efter denne metode en spænding mellem 2 strømelektroder, der stikkes i jorden med en passende afstand. Mellem strømelektroderne anbringes to potentialelektroder på linie med strømelektroderne. Potentialelektrodernes indbyrdes afstand 
og afstanden mellem strøm- og følgende potentialelektrode er $\frac{1}{3}$ af afstanden mellem strømelektroderne $(=a)$. Potentialelektroderne fører til et voltmeter eller en spændingsspole i et ohmmeter, hvorved potentialforskellen mellem potentialelektroderne kan måles, når disse er placeret i jorden i punkter af det af strømelektroderne frembragte elektriske felt som skitseret i fig. 2. Man kan på denne måde få et udtryk for jordens ledningsevne imellem potentialelektroderne.

Betragter man en elektrisk strøm $I$, der ved elektroden $E$ (fig. 1) føres til jorden, som forudsættes homogen og har en specifik modstand $\varrho$, vil potentialet $V$ i et punkt $P$ i afstanden $r$ fra strømkilden være: $V=\varrho \frac{I}{2 \pi r}$

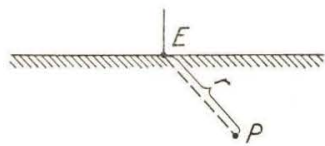

Fig. 1.

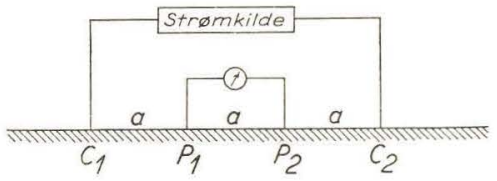

Fig. 2.

Med den samme forudsætning af jordens homogenitet kan potentialforskellen mellem to potentialelektroder i et Wenner-system beregnes ved at betragte forskellen imellem potentialerne ved de to potentialelektroder $\left(P_{1}\right.$ og $\left.P_{2}\right)$, som frembringes ved, at strøm føres henholdsvis til og fra de to strømelektroder $C_{1}$ og $C_{2}$ (fig. 2) (Wenner 1915, NetTleton 1940).

Potentialet ved $P_{1}$ på grund af strømmen, der ledes til jorden ved $C_{1}$ er $\varrho \frac{I}{2 \pi a}$, og potentialet, der skyldes strømmen, som forlader jorden ved $C_{2}$ er $-\varrho \frac{I}{2 \pi \cdot 2 a}$. Det samlede potential ved $P_{1}$ er således:

$$
V_{1}=\varrho \frac{I}{2 \pi}\left(\frac{1}{a}-\frac{1}{2 a}\right)=\varrho \frac{I}{2 \pi}\left(\frac{1}{2 a}\right)
$$

På samme måde fås potentialet ved $P_{2}$ :

$$
V_{2}=\varrho \frac{I}{2 \pi}\left(-\frac{1}{a}+\frac{1}{2 a}\right)=-\varrho \frac{I}{2 \pi}\left(\frac{1}{2 a}\right)
$$

Potentialforskellen imellem $P_{1}$ og $P_{2}$ er således:

$$
V=V_{1}-V_{2}=\varrho \frac{I}{2 \pi a}
$$


Med anvendelsen af dette elektrodesystem er jordens specifike modstand altså :

$$
\varrho=\frac{V}{I} \cdot 2 \pi a
$$

$V$ repræsenterer som nævnt potentialforskellen imellem potentialelektroderne og $I$ den i kredsen forløbende strøm. Ved de fleste instrumenter måles disse individuelle størrelser ikke, men derimod den samlede modstand $R$, som strømmen gennemløber mellem potentialelektrodernes ækvipotentialflader. Da $R$ ifølge Ohms lov er lig $\frac{V}{I}$ kan formlen herefter skrives:

$$
\varrho=2 \pi \cdot a \cdot R
$$

Ved hjælp af denne formel kan man altså beregne jordens specifike modstand, hvilket også er sket ved D.G.U.'s målinger i 1953.

Under den givne forudsætning, at jorden er homogen, kan man vise, at halvdelen af strømmen passerer gennem et vertikalplan midt imellem de to strømelektroder, vinkelret på deres forbindelseslinie, ovenfor en dybde, der er lig med halvdelen af afstanden mellem de to strømelektro-

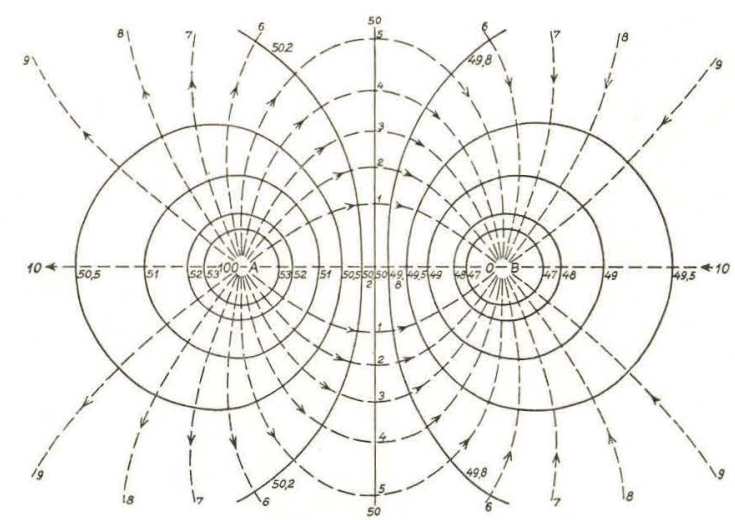

Fig. 3. Elektrisk strømfelt i homogen jord. Akvipotentialfladernes skæring med billedplanet vist ved fuldt optrukne linier og strømlinier vist ved stiplede linier. Strømliniernes retning er betinget af, at den i ethvert punkt er vinkelret på ækvipotentialfladen gennem punktet. (Efter SCHLUMBERGER 1930).

der $\left(\frac{3}{2} a\right)$. Den anden halvdel af strømmen passerer under denne dybde (se f. eks. Nettleton 1940). Indtrængningsdybden for halvdelen af strømmen er således afhængig af elektrodeafstanden. Forøges elektrodeafstanden, trænger denne del af den elektriske strøm dybere ned i jorden. Fig. 3 er en skematisk fremstilling af strømliniernes fordeling mellem to poler $A$ og $B$ og ækvipotentialfladernes skæring med billedplanet. Drejes 
billedet om aksen $A$ - $B$ i lodret stilling og sættes $A-B$ lig med jordoverfladen, fås et indtryk af strømmens fordeling i dybet under $A-B$.

Den opstillede forudsætning om jordens homogenitet træffes meget sjældent i naturen. Anvendes formlen derfor i praksis ved modstandsmålinger vil @ repræsentere en tilsyneladende specifik modstand, en slags gennemsnitsværdi af alle specifike modstande (både for flydende og faste bestanddele i jordlagene), som strømmen ved den pågældende elektrodeanordning gennemløber. Modstanden afhænger navnlig af jordlagene mellem potentialelektroderne med et tværsnit, der svarer til kvadratet på halvdelen af afstanden mellem strømelektroderne $\left(\frac{3}{2} a\right)^{2}(\mathrm{WEx}$ NER).

Foretages en række modstandsmålinger omkring samme punkt med stadig større spredning af elektrodesystemet (forøgelse af $a$ ) vil strømmen samtidig trænge ned til større og større dybde og derved inddrages de tilsvarende lags modstande i udtrykket for @. En grafisk fremstilling i form af en kurve, der viser afhængigheden mellem den tils ynelad en de specifike modstand og elektrodeafstanden $a$ vil kunne give oplysninger om de enkelte lags sande specifike modstande og om dybden, hvori lagene forekommer. Denne opmålingsteknik benævnes punktprofilopmåling, idet man med den gældende tilnærmelse kan sige, at man måler modstandsværdier for lagene under centret af elektrodesystemet, der ligger fast under målingerne.

Den tilsyneladende specifike modstand $\varrho_{a}$, svarende til elektrodeafstanden $a$ i den Wenner'ske opstilling kan f. eks. afbildes i et retvinklet, dobbeltlogaritmisk koordinatsystem ved en kurve, der viser afhængigheden mellem $\varrho_{a}$ og elektrodeafstanden $a$.

Udledningen af Wenner's formel forudsætter som nævnt homogenitet i jordlagene, der inddrages i målingerne, og derved også samme specifike modstand. Disse ideelle forhold vil naturligvis bevirke, at kurven for $\varrho_{a}$ fremtræder som en vandret, ret linie.

Anvendes Wenner's metode til udregningen af den tilsyneladende specifike modstand $\varrho_{a}$ efter Wenners formel ved modstandsmålinger over vekslende lag, altså ud over formlens forudsætninger, vil $\varrho_{a}$-kurven naturligvis kun ved små værdier af $a$ være en vandret linie. Ved målinger med større $a$-værdier får man efterhånden en påvirkning af dybereliggende lag, hvis modstand afviger fra overfladelagets. Kurvens form kan være yderst varierende.

Forskellige forskere som H. Hedström (1928), J. N. Hummel (1929), TAGG (1931) (jfr. HEILAND) m. fl. har udregnet formler og kurver for $\varrho_{a}$ i forhold til $a$ ved to- og flerlagssystemer med planparallele grænser. For et tolagssystem, hvor det øverste lag har mægtigheden $h$ og sand specifik modstand $\varrho_{1}$, og det underliggende lag strækker sig til større dybde, end målingen i praksis indbefatter, og har sand specifik modstand 
$\varrho_{2}$, fandt Hummel følgende uendelige række som udtryk for den tilsyneladende specifike resistivitet:

$$
\frac{\varrho_{a}}{\varrho_{1}}=1+4 \sum_{n=1}^{\infty}\left\{\frac{\left[\left(1-\frac{\varrho_{1}}{\varrho_{2}}\right):\left(1+\frac{\varrho_{1}}{\varrho_{2}}\right)\right]^{n}}{\sqrt{1+\left(2 n \frac{h}{a}\right)^{2}}}-\frac{\left[\left(1-\frac{\varrho_{1}}{\varrho_{2}}\right):\left(1+\frac{\varrho_{1}}{\varrho_{2}}\right)\right]^{n}}{\sqrt{4+\left(2 n \frac{h}{a}\right)^{2}}}\right\}
$$

Udtrykket $\left(1-\frac{\varrho_{1}}{\varrho_{2}}\right):\left(1+\frac{\varrho_{1}}{\varrho_{2}}\right)=\frac{\varrho_{2}-\varrho_{1}}{\varrho_{2}+\varrho_{1}}$ benævnes $k$ og herefter kan formlen også skrives:

$$
\varrho_{a}=\varrho_{1}\left\{1+4 \sum_{n=1}^{\infty} k^{n}\left[\frac{1}{\sqrt{1+\left(2 n \frac{h}{a}\right)^{2}}}-\frac{1}{\sqrt{4+\left(2 n \frac{h}{a}\right)^{2}}}\right]\right\}
$$

Ved målinger kan $\varrho_{1}$ måles indledningsvis ved en tilstrækkelig lille elektrodeafstand, medens målinger med større $a$ giver udtryk for $\varrho_{a}$, der ved ligning (6) fremstilles ved de fire uafhængigt variable $a, h, k$ og $\varrho_{1}$.

Med hensyn til udledningen af formlerne (5) og (6) må der henvises til den geofysiske faglitteratur (se f. eks. Heiland 1951). Der er grund til i denne forbindelse at pege på det interessante forhold, at resistivitetsmetoder på mange måder viser lighedstræk med seismiske refraktionsmetoder.

De benyttede beregninger og formler gælder for jævnstrøm. De viser, at jævnstrømmens effektive indtrængningsdybde i homogen jord kun er afhængig af elektrodeafstanden. Der er således teoretisk ingen grænse for, hvor dybt man kan nå med jævnstrømsmålinger.

Anvendes vekselstrøm gælder formlerne med en vis tilnærmelse, så længe der er tale om lave frekvenser. Indtrængningsdybden for vekselstrøm er bl. a. en funktion af frekvensen og jordens ledningsevne $\sigma$; indtrængningsdybden aftager med stigende frekvens.

Til trods for vekselstrømsmålingernes begrænsninger foretrækkes de ofte, da de af forskellige årsager er lettere at udføre (se den geofysiske litteratur).

TAGG og andre har udarbejdet kurveskarer, der for de enkelte værdier af $a$ giver $\frac{\varrho_{a}}{\varrho_{1}}$ som funktion af $h$, med $k$-værdierne $1 ; 0,9 ; 0,8 \ldots 0 \ldots$ $-0,9 ;-1$ som kurveparametre (se f. eks. Hallenbach 1943 og HeiLAND 1951). Metoden er udvidet til også at kunne anvendes ved flere lag. Efter at $h_{1}, \varrho_{1}$ og $\varrho_{2}$ er bestemt som antydet ovenfor, bliver de to øverste 
lags modstande beregningsmæssigt sammenfattet til een modstand $\varrho_{m}$. Dybden $h_{2}$ til den næste laggrænse kan herefter beregnes som ovenfor. Efter denne fremgangsmåde kan man under forudsætning af en vis lagtykkelse teoretisk beregne dybden til alle laggrænser i et planparallelt system.

Ved den af D.G.U. anvendte praksis har det været muligt at udnytte A/B Elektrisk Malmletnings beregningsmetode, som er baseret på en ikke publiceret teoretisk behandling af hele problemkomplexet, udarbejdet i manuskript i 1928 af ingeniør H. Hedströм. Manuskriptet og de beregnede kurver, der repræsenterer en betydelig arbejdsindsats, er på velvilligste måde stillet til vor rådighed af forfatteren.

Efter Henströms metode anbringes den på gennemsigtigt papir optegnede empiriske kurve, der viser, de målte $\varrho_{a}$-værdier som funktion af $a$ akseparallelt på de beregnede kurver (diagram I, fig. 4), således at den empiriske kurves første del dækker en af diagrammets $\frac{\varrho_{a}}{\varrho_{1}} \frac{a}{h}$ kurver. Den pågældende kurves parameter giver umiddelbart et udtryk for $\frac{Q_{2}}{\varrho_{1}}$ medens $h_{1}$ og $\varrho_{1}$ fås ved koordinaterne af punktet $P\left(\frac{a}{h}=1, \frac{\varrho_{2}}{\varrho_{1}}=1\right)$ i koordinatsystemet for den empiriske kurve, hvor dette punkt kaldes $A$. Hermed er de specifike modstande af de 2 øverste og tykkelsen af det øverste lag kendt.

Idet $h_{1}$ er tykkelsen af det øverste lag og $h_{2}$ af de to øverste lag, $\varrho_{1}$ og $\varrho_{2}$ de specifike modstande for disse to lag og $\varrho_{m}$ gennemsnitsregneværdien af den specifike modstand for de to sammenfattede lag har HEDSTRöM afbildet kurveskarer for $\frac{\varrho_{m}}{\varrho_{1}}$ som ifølge KIRcHноFFs udtryk

$$
\frac{\varrho_{m}}{\varrho_{1}}=\frac{\varrho_{2}}{\varrho_{1}}=\frac{\frac{h_{2}}{h_{1}}}{\frac{\varrho_{2}}{\varrho_{1}}+\frac{h_{2}}{h_{1}}-1}
$$

er en funktion af de 2 uafhængigt variable $\frac{h_{2}}{h_{1}}$ og $\frac{\varrho_{2}}{\varrho_{1}}$ med parametre $\frac{\varrho_{2}}{\varrho_{1}}$ og abscisser $\frac{h_{2}}{h_{1}}$ (diagram II fig. 5).

Det empiriske diagram anbringes akseparallelt på diagram II, således at $A$ falder i dette diagrams $P_{1}\left(\frac{h_{2}}{h_{1}}=1, \frac{\varrho_{m}}{\varrho_{1}}=1\right)$ og den til den i diagram I fundne $\frac{\varrho_{2}}{\varrho_{1}}$-værdi svarende kurve i diagram II indtegnes på det empiriske diagram. Ovennævnte fremgangsmåde gentages nu, idet punkt $P$ på dia- 


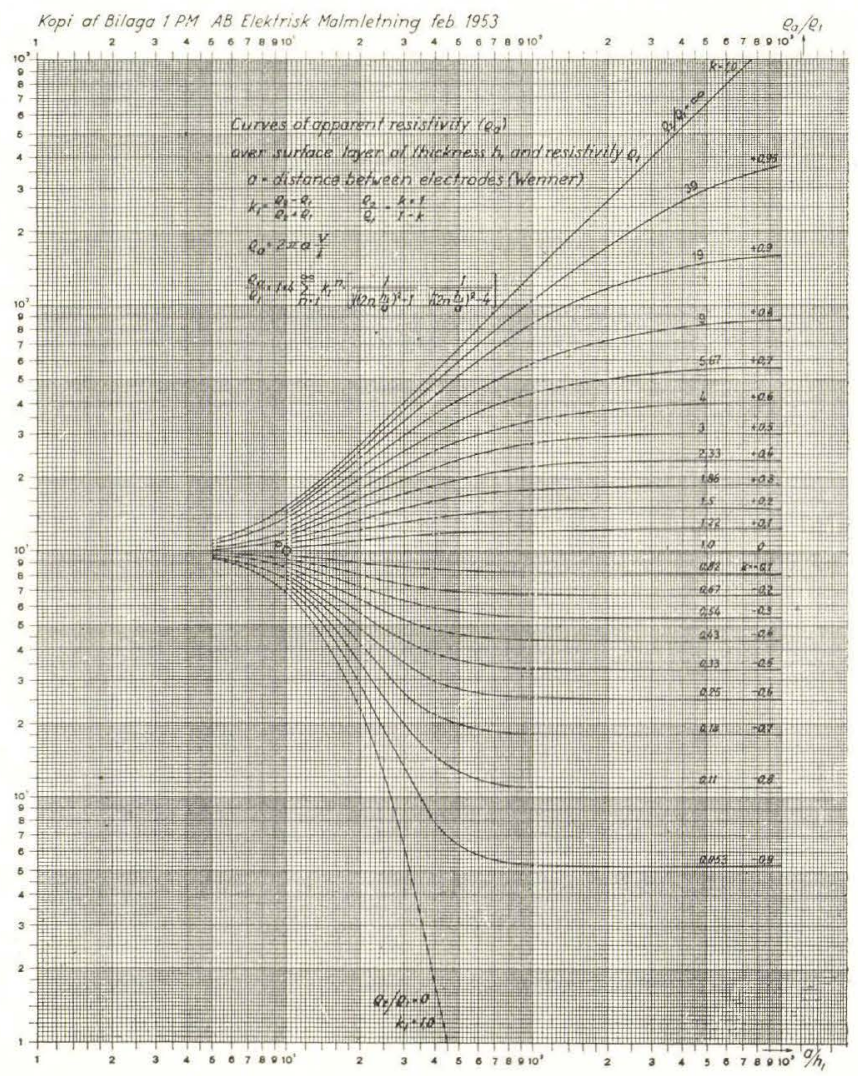

Fig. 4. Kurver, der viser den tilsyneladende modstand $\varrho_{a}$ ved overfladen af et lag med mægtighed $h_{1}$ og specifik modstand $\varrho_{1}$ underlejret af lag med specifik modstand $\varrho_{2}$. $a=$ elektrodeafstand (Wenner system). Se iøvrigt teksten side 17 .

Curves of apparent resistivity $\varrho_{a}$ over surface layer of thickness $h_{1}$ and resistivity $\varrho_{1}$ underlaid by layer of resistivity $\varrho_{2} ; a=$ distance of electrodes (Wenner system). According to Hedström 1953.

gram I glider akseparallelt hen ad den indtegnede kurve, indtil den empiriske kurve atter på et stykke falder sammen med en kurve på diagram I. Punktet på $\frac{\varrho_{m}}{\varrho_{1}}$ kurven, hvor $P$ ligger ved denne 2. dækning angiver ved sine koordinater i diagrammet med den empiriske kurve $h_{2}$ og $\varrho_{m}$, medens kurven på diagram I svarende til dækning 2 med sine parametre 》 $\frac{\varrho_{2}}{\varrho_{1}}$ 《angiver $\frac{\varrho_{3}}{\varrho_{m}}$, idet man som nævnt har slået $\varrho_{1}$ og $\varrho_{2}$ lagene sammen til eet med den specifike modstand $\varrho_{m}$. Det tredie lag $\left(\varrho_{3}\right)$ optræder altså nu overfor det forenede $\varrho_{1}-\varrho_{2}$ lag som tidligere det andet $\left(\varrho_{2}\right)$ overfor det første $\left(\varrho_{1}\right)$. Dermed er $h_{2}$ og $\varrho_{3}$ kendte. 


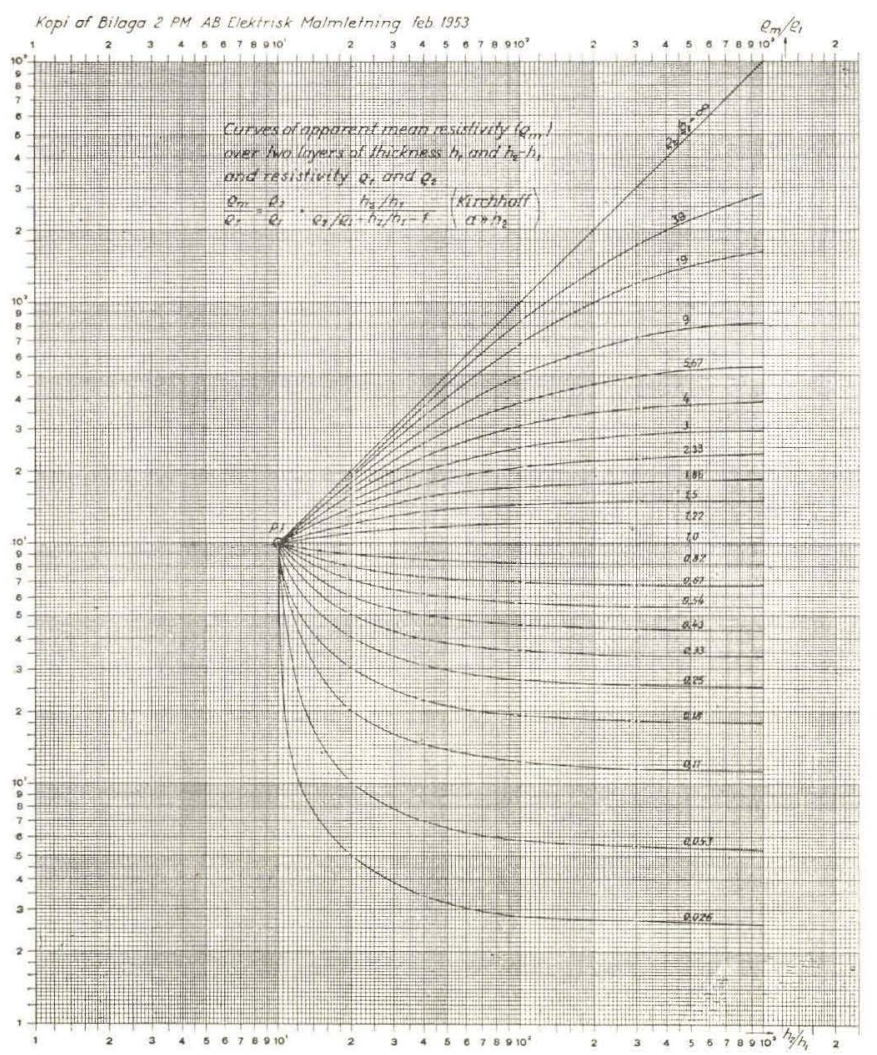

Fig. 5. Kurver, der viser den tilsyneladende gennemsnitsmodstand $\varrho_{m}$ ved overfladen af to lag med mægtighederne $h_{1}$ og $h_{2}-h_{1}$ og de specifike modstande $\varrho_{1}$ og $\varrho_{2}$. Se iøvrigt teksten side 17 .

Curves of apparent mean resistivity $\varrho_{m}$ over two layers of thickness $h_{1}$ and $h_{2}-h_{1}$ and resistivity $\varrho_{1}$ and $\varrho_{2}$. According to Hedström 1953.

Fremgangsmåden gentages, indtil hele den empiriske kurve fra opmålingen er behandlet.

\section{Linieprofilopmåling.}

Ved en anden målemetode flyttes hele elektrodesystemet med stadig samme elektrodeafstand $a$ langs en på forhånd i terrænet fastlagt linie til afmærkede målepunkter med samme indbyrdes afstand, der oftest er lig med $a$ eller lig med et simpelt multiplum af $a$.

Denne fremgangsmåde kaldes linieopmåling, kartering eller trenching. Man opnår ved den en række modstandsværdier, der med en vis tilnærmelse er udtryk for jordmodstanden til samme dybde.

Ved en passende placering af linieprofiler i et afgrænset terrænom- 
råde vil man således opnå en række modstandsværdier, der giver en oversigt over den horisontale variation af lagserien til en bestemt dybde. I praksis har man lov til at regne med, at det fortrinsvis er lagene, der fra terrænoverfladen strækker sig ned til en dybde mellem $a$ og $\frac{3}{2} a$, hvis modstande udtrykkes ved $R$, og man regner simpelthen med, at @ repræsenterer modstanden for lagene til dybden $a$.

\section{Indflydelsen af heterogeniteter i jordskorpen.}

De opstillede idealtilfælde for udledningen af formlerne, der som nævnt omfatter, at jordlagene skal være homogene, at flerlagssystemer skal være planparallelle og have en vis udstrækning o. s. v. findes yderst sjældent og muligvis aldrig i naturen. Det har derfor en betydelig interesse for geoelektriske metoders praktiske anvendelse, at man beregningsmæssigt, experimentelt og empirisk danner sig et overblik over, hvorledes heterogeniteter af forskellig art i jordskorpen indvirker på de elektriske felter og de i forbindelse hermed udførte målinger. Selv de simpleste kombinationer af heterogeniteter i jordlagene er i fysisk-matematisk henseende så komplicerede, at man ved et forsøg på en forståelse af elektriske felters reaktioner i forhold hertil i de fleste tilfœlde må nøjes med at anstille enkle generaliserende betragtninger. Som et eksempel herpå skal gode og dårlige lederes indflydelse på et elektrisk jordfelt illustreres i det følgende (væsentligt efter Schlumberger 1930).

Fig. 3, side 14 viser et idealiseret, elektrisk felt omkring to strømkilder. Man kan forestille sig to elektroder stukket ned i homogen jord set fra oven. Potentialet bevæger sig fra 100 ved $A$ til 0 ved $B$. De fuldt optrukne linier er ækvipotentialfladernes skæring med jordoverfladen. Akvipotentialfladerne nærmest polerne $A$ og $B$ er meget nær halvkugleformede. Den elektriske strøm bevæger sig som bekendt vinkelret på ækvipotentialfladerne og er symboliseret ved de med pile forsynede punkterede strømlinier. Rejses figuren op i lodret stilling kan dens nedre halvdel under linie $A-B$ opfattes som en fremstilling af ækvipotentialflade- og strømlinieforløbet i et lodret snit i jorden under linie $A-B$.

Anbringes et stærkt ledende legeme i dette elektriske felt midt imellem $A$ og $B$ som antydet i fig. 6 (lodrette potentialflader) vil potentialforskellen indenfor dette legeme naturligvis være ringe. Dette kan også udtrykkes på den måde, at det ledende legeme støder ækvipotentialfladerne bort fra sig, og da strømmen går vinkelret på disse, indsuger det ledende legeme samtidigt de elektriske strømlinier, som vist på figuren.

Findes et absolut ikke-ledende legeme, en isolator, på samme sted, vil strømmen naturligvis gå uden om dette, og da ækvipotentialfladerne er vinkelrette på strømretningen, vil de få et forløb som gengivet skematisk på fig. 7. I lighed med ovenstående udtryksmåde for det ledende legeme 


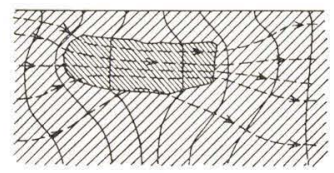

Fig. 6. Stærkt ledende legeme midt i et potentialfelt, hvor ækvipotentialfladerne normalt er lodrette (f. eks. midt mellem $A \operatorname{og} B$ på fig. 3 , side 14). Optrukne linier: billedplanets skæring med ækvipotentialfladerne, strømlinier stiplet. (Væsentlig efter SCHLUMBERGER 1930).

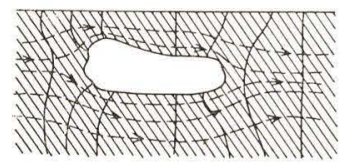

Fig. 7. Ikke-ledende legeme midt i potentialfelt, hvor akvipotentialfladerne normalt er lodrette. Optrukne linier: ækvipotentialflader; stiplede linier: strømlinier. Sammenlign med fig. 6. (Væsentlig efter SCHLUMBERGER 1930).

kan man sige, at en svagt ledende masse vil "tiltrække« ækvipotentialfladerne og støde strømlinierne bort fra sig.

De skematiske tegninger giver ligeledes en forestilling om, at den ved overfladen registrerbare effekt af en inhomogenitet i jorden er afhængig af dens afstand fra jordoverfladen og af dens størrelse.

Indvirkningen af en særlig hyppigt forekommende inhomogenitet i naturen, forkastningsstrukturen, på et elektrisk felt er blevet beregnet af TAGg (se f. eks. HeIland 1951). TagG fandt, at en lodret forkastning,

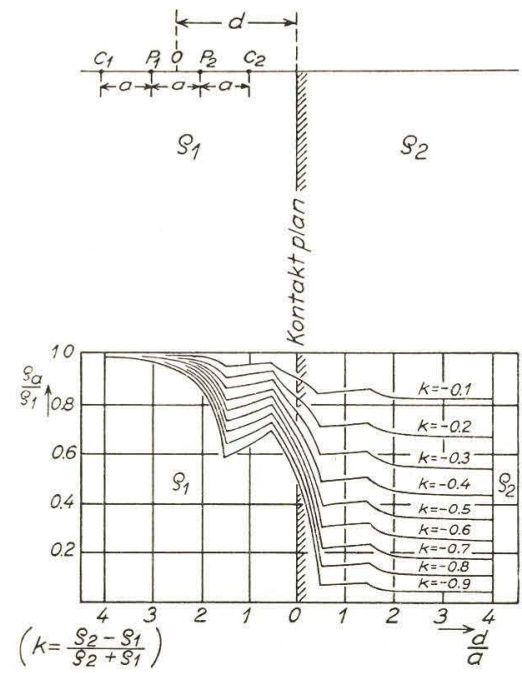

Fig. 8. Tilsyneladende modstande ved måling med 4-elektrode system ved en kontakt mellem to bjergarter med modstandene $Q_{1}$ og $\varrho_{2}$ udtrykt som funktion af afstanden $d$ fra systemets centrum 0 til kontaktplanet med $a$ som enhed (efter TAGG).

som når op til jordoverfladen, ikke øver nogen praktisk indflydelse på et Wennersystem, som er orienteret vinkelret på forkastningen, når centret for elektrodesystemet ligger i større afstand fra forkastningen end $4 a$ (se fig. 8). 
Denne erfaring kan også anvendes ved en betragtning over, hvilke krav man må stille til jordlagenes horisontale udstrækning for udførelsen af en punktprofilopmåling. Idet $a$ i praksis sættes lig med den dybde, som målingerne omfatter, viser eksemplet med forkastningens indflydelse, at udstrækningen af lagene helst bør være $8 a$; i praksis regner man dog med, at $5-6 a$ er tilstrækkeligt. 


\section{Undersøgelserne i året 1953.}

Apparatur og operationer i marken. Ved D.G.U.'s undersøgelse af jordmodstanden efter WEnnens metode er anvendt A/B Elektrisk Malmletnings »Earth Resistivity Meter type 766, no. 19《, der blev taget i brug d. 16/2 1953. Fig. 9 viser et apparat af denne type. Apparatet indeholder en hånddreven generator med måleudrustning opfattende dekademodstand, forstærker, galvanometer m. m. Ved en omdrejningshastighed på ca. 40 omdrejninger/min. udvikles $125 \mathrm{~V}$, og der frembringes en strøm med en frekvens på $16 \mathrm{~Hz}$. Dekademodstanden kan virke over følgende

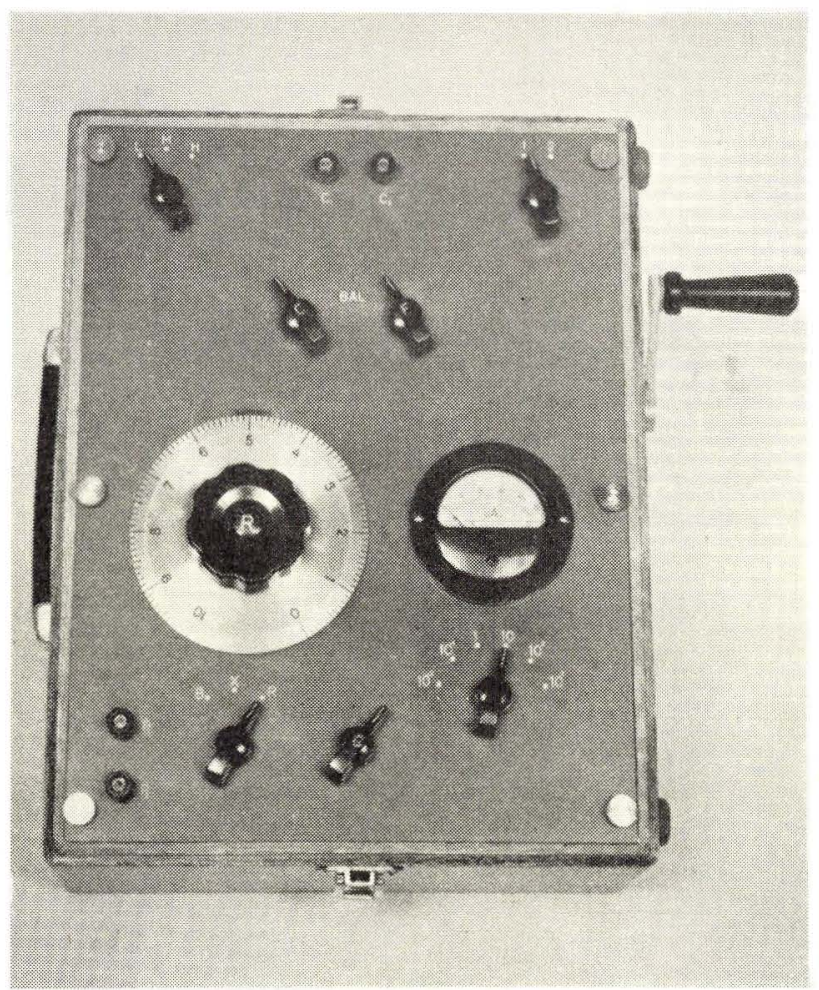

Fig. 9. Apparat til måling af elektrisk jordmodstand. (A. B. Elektrisk Malmletning). 
6 intervaller: $0-0,1,0-1,0,0-10,0,0-100,0-1000$ og $0-10000$ ohm, idet hvert interval således kan inddeles i hundrededele. Aflæsningen kan foretages ned til $0,01 \mathrm{ohm}$ med en nøjagtighed på $\pm 3 \%$ eller nøjagtigere.

Til feltudrustningen hører desuden: kabler, stålelektroder, målebånd, målestænger, lommebøger og topografiske kort. Transporten af personel og materiel i marken er ved D.G.U.'s undersøgelser foregået i bil. Et opmålingshold omfatter en leder med 3 til 4 hjælpere.

Linie- og punktprofiler indmåles nøjagtigt med målebånd ved hjælp af topografiske kort i 1:20.000 eller helst i 1:5000. Det nævnte antal hjælpere er nødvendigt for at undgå for stor spild af arbejdstid ved udlægningen af linier og flytningen af elektrodesystemet. Målingen af modstanden foregår i principet på den måde, at man først måler modstanden mellem potentialelektroderne $P_{1}$ og $P_{2}$, aflæser galvanometret og derefter indskyder en modstand, der giver samme udslag på galvanometret. Denne modstand er lig med modstanden mellem $P_{1}$ og $P_{2}=R$ (jfr. side 14), og herefter kan den tilsyneladende specifike modstand $\varrho_{a}$ beregnes efter formel (4) side 14.

Fig. 10 viser skemaet for målingen, idet galvanometeret forbindes henholdsvis med $P_{1}$ og $P_{2}$, som vist ved $1-1$, og med modstanden $A C$ over

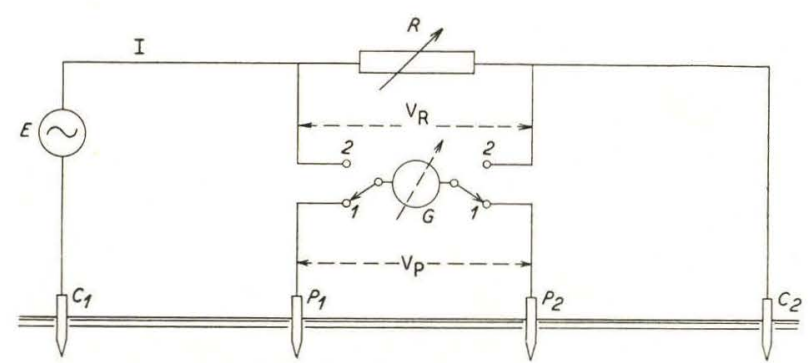

Fig. 10. Skema for måling af jordmodstand. $P_{1}-P_{2}$ : potentialelektroder, $C_{1}-C_{2}$ : strømelektroder, $R$ : dekademodstand, $V_{P}$ : potentialfald over potentialelektroderne, $V_{R}$ : potentialfald over dekademodstand, $G$ : galvanometer, $E$ : generator, $I$ : elektrisk strøm. (Efter A. B. Elektrisk Malmletining).

2-2. $V_{P}$ og $V_{R}$ symboliserer de tilsvarende potentialforskelle (som ved samme galvanometerudslag er ens), $E$ generatoren og $I$ den i kredsen forløbende strøm.

Arbejdsprogram. For D.G.U.'s resistivitets-undersøgelser, blev der lagt følgende program:

1. Opmåling af profiler efter punktprofil- og linieprofilmetoden på udvalgte steder, hvor hovedtrækkene i de geo-hydrologiske forhold er kendt.

a. Formålet med punktprofilerne:

Undersøgelsen af metodens anvendelighed ved bestemmelsen af 
grundvandspejlets højde, de forskellige jordlags specifike modstande og dybderne for laggrænserne imellem lagene, der omfattes af målingerne.

b. Formålet med linieprofilerne:

Undersøgelsen af mulighederne for kortlægning af istidsdannelser, optrængende saltvand og ujævnheder i prækvartæroverfladen (dybe dale i kalkundergrunden, forkastninger o. s. v.).

2. Opmåling af profiler efter punktprofil- og linieprofilmetoden på steder, hvor de geo-hydrologiske forhold kun er delvis kendte, og hvor man ved senere boringer vil kunne kontrollere de geologiske fortolkninger, som forinden bør gennemføres på grundlag af de geoelektriske målinger. Der bør forsøges udført målinger i forbindelse med de samme emner, som er nævnt under programmets punkter la og 1 b.

På forhånd måtte man vente, at de kvartære jordlags ofte ret forstyrrede lagstilling ville være alvorlige hindringer ved fortolkningen af geoelektriske målinger i Danmark. Særlige vanskeligheder forudsås ved fortolkningen af punktprofiler, idet sikkerheden med hensyn til ensartet lagdeling over en horisontal strækning på 5-6a måtte anses for problematisk i mange egne, såsnart $a$ når op på en tilstrækkelig størrelse.

På baggrund af disse overvejelser blev der udarbejdet en undersøgelsesmetodik gående ud på at opsøge så jævnt terræn som muligt og at dække de enkelte områder med et passende net af linieprofiler med elektrodeafstande, som i hvert enkelt tilfælde skulle fastlægges efter opgavens art. I almindelighed skulle områder med grundvandspejlet i nærheden af terræn foretrækkes, for at den eventuelt kraftige indflydelse af højtliggende terræn over grundvandspejlet som modstandsfaktor derved skulle kunne elimineres. Kurvekort fremstillet på grundlag af linieprofilernes modstandsværdier skulle danne grundlaget for afgrænsningen af eventuelle modstandsanomalier. Punktprofiler agtedes udført dels i tilknytning til liniekortlægningen og dels som uafhængige undersøgelser i egnet terræn med tilstrækkeligt ensartede geologiske forhold.

Undersøgelsesprogrammet er udarbejdet og tilrettelagt af forfatteren, som også har ledet arbejdet. Udvælgelsen af undersøgelsesområder er navnlig sket på grundlag af oplysninger om boringer m. v. i D.G.U.'s borearkiv.

Arbejdet i terrænet er i tiden $16 / 2-20 / 5$ og 4/11-16/12 udført af civilingeniør P. Holm Andersen, og i tidsrummet 15/7-24/10 har stud. mag. Niels Viggo Jessen og stud. polyt. Buarne Micheelsen varetaget denne del af arbejdet.

Rentegningen af profiler og kort er foretaget af fru ULLA ANDERSEN, f. Grønyold frk. Inger Petersen og fru Rigmor Rasmussen på D.G.U.'s tegnestue. 
Bearbejdelsen af materialet er sket ved forfatteren.

Punktprofilerne er målt for $a$-værdierne: $0,2,0,3,0,5,0,8,1,2,1,8,3,5$, $8,12,18,30,50,80,120,180 \mathrm{og} 300 \mathrm{~m}$. De er fremstillet grafisk på dobbeltlogaritmisk papir ved at afbilde de beregnede tilsyneladende modstande i forhold til de tilsvarende $a$-værdier. Langs $a$-aksen er endvidere indtegnet et boreprofil, når profilpunktet svarer til eller ligger nær ved en boring. I de tilfælde, hvor der ikke findes en boring i tilknytning til profilpunktet, har jeg så vidt muligt ved hjælp af omkringliggende boringer bestemt forskellige niveauflader som f. eks. grundvandspejlet, kalkoverfladen o. s. v. ved interpolation.

Linieprofilopmålingerne er fremstillet grafisk på almindeligt millimeterpapir ved med profillinien som $x$-akse at afsætte $R$-værdierne som ordinater ud for de respektive positioner, hvorefter de således bestemte punkter er forbundet med rette linier. (Kun et enkelt grafisk linieprofil gengives dog i dette arbejde).

Der er tegnet kurvekort i 1:5000 (forstørrede udsnit af målebordsblade), hvorpå linierne og positionerne med deres $R$-værdier er afmærket. Iso-ohm kurver forbinder punkter med samme $R$-værdier i de tilfælde, hvor det skønnedes rimeligt at tegne sådanne kurver. Den geologiske fortolkning er væsentligt sket på grundlag af Iso-ohm kurvekortene.

Kortene, der oprindeligt er fremstillet som arbejdskort, afbilder for nemheds skyld $R$ og ikke $\varrho$. Ved at multiplicere tal- og kurveværdier med faktoren 157 på kortene med $a=25 \mathrm{~m}$ og med 314 på kortene, hvor $a=50 \mathrm{~m}$ fås modstanden udtrykt i ohm meter.

\section{Undersøgelserne.}

1. Herstedøster. Til den første punktprofilopmåling valgtes et område mellem Herstedøster og Hvessinge (målebordsblad M 3129. Fig. 11) med terrænhøjden ca. +24 m, idet man efter boringer i området måtte skønne, at der skulle foreligge forholdsvis ensartede geologiske forhold. Som eksempel på lagserien citeres boreprofilet for den nærmeste boring ca. $300 \mathrm{~m}$ syd for punktprofilet 200.1. Herstedøster.

Arkiv nr. 200.662. Herstedøster.

Gartner Hansen, Gl. Landevej. Boring udført 1947 af ingeniør P. Hasbo.

$$
\begin{aligned}
& \text { ea. }+23 \mathrm{~m} \quad 0-5 \quad \mathrm{~m} \text { Brønd } \\
& 5 \text { - } 8,9 \text { m Ler } \\
& +14,1 \mathrm{~m} \quad 8,9-11,5 \mathrm{~m} \text { Bryozokalk } \\
& \text { 11,5-31,4 } \mathrm{m} \text { »Kalk med enkelte flintlag" (ingen prøver fra 11,5- } \\
& 31,4 \mathrm{~m}) \text {. Vandrejsning } 8,5 \mathrm{~m} \text { under terræn. }
\end{aligned}
$$

Punktprofilet 200.1 Herstedøster. 16/2 1953 gav følgende resultat, idet fortolkning og forskellige niveauer, beregnet på grundlag af boringer i området, er anført til sammenligning (tavle I, fig. 1): 


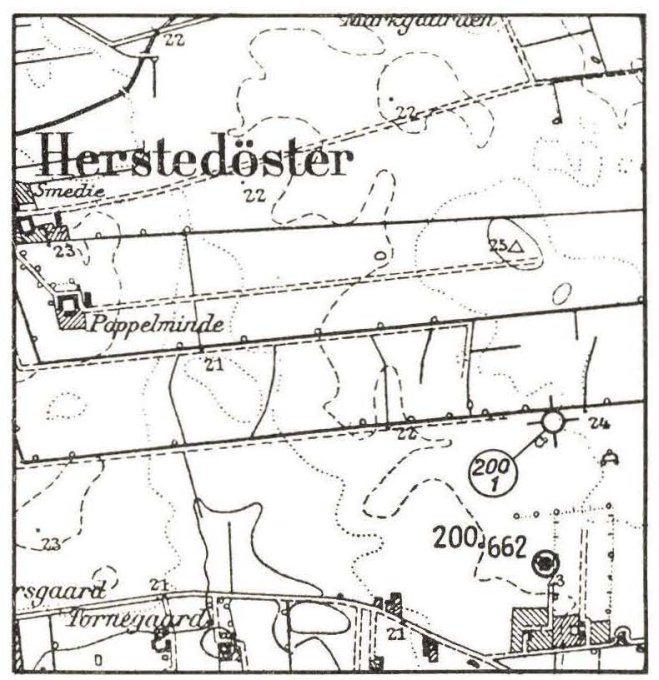

Fig. 11. Herstedøster. Beliggenhed af punktprofil nr. 200.1 og boring nr. 200.662. Autoriseret reproduktion efter Geodætisk Institut M. 3129. 1:20 000.

Location of electrical drilling no. 200.1, and well no. 200.662. Scale 1:20 000.

\begin{tabular}{|c|c|c|c|}
\hline Dybde: & Q (ohmmeter) & Fortolkning: & Beregnede niveauer. Dybde (ca). \\
\hline $0-0,6 \mathrm{~m}$ & 1300 & Muldlag & \\
\hline $0,6-11,5 \mathrm{~m}$ & 52 & $\left\{\begin{array}{l}\text { Kvartær } \\
\text { (Moræneler) }\end{array}\right.$ & $9 \mathrm{~m}$ Grundvandspejl \\
\hline $11,5-19,5 \mathrm{~m}$ & 531 & |Bryozokalk & $10 \mathrm{~m}$ Bryozokalkoverflade \\
\hline $19,5-90 \quad \mathrm{~m}$ & 352 & Jog skrivekridt & $60 \mathrm{~m}$ Skrivekridtoverflade \\
\hline $90-? \mathrm{~m}$ & 59 & $\begin{array}{l}\text { Saltvand i } \\
\text { skrivekridtet }\end{array}$ & \\
\hline
\end{tabular}

Det er sandsynligt, at det fugtige moræneler over kalken er så ensartet og indeholder så meget porevand, at man ikke kan vente en resistivitets diskontinuitet i det niveau, hvor kalkens teoretiske grundvandspejl findes. Der er heller intet holdepunkt for ved hjælp af modstandskurven at skelne mellem bryozokalk og skrivekridt i dette terræn. Modstandsfaldet i ca. $90 \mathrm{~m}$ dybde er på den anden side så kraftigt, at det er rimeligt at sætte det i forbindelse med tilstedeværelsen af saltvand, som må antages at have en vid udbredelse i de dybere dele af skrivekridtet.

2. Lille Linde, Stevns og Karise. I tilslutning til målingen ved Herstedøster udvalgtes en række målepunkter ved Lille Linde og på Stevns i områder, hvor kvartæret må skønnes at være nogenlunde ensartet, og hvor bryozokalkoverfladens højde er godt kendt på grundlag af 
oplysninger om jordlagene i boringer og brønde. Grænsen mellem bryozokalken og det underliggende skrivekridt kan man desuden beregne med relativ god nøjagtighed ved hjælp af iagttagelserne over denne flades højdeforhold i Stevns Klint og ved at støtte sig til observationerne over skrivekridtets overflade i enkelte dybere boringer, som er udført ved Hårlev, Hellested, Karise, Holtug og Store og Lille Heddinge m. v., hvor skrivekridtet er overlejret af danskekalk.

Formålet med de planlagte punktprofiler i dette terræn var at undersøge, om kvartær, bryozokalk og skrivekridt samt grundvandsregionen ville vise tilstrækkelig afvigelse med hensyn til de elektriske modstande, til at forskellene ville kunne gøre sig gældende i modstandskurvernes form.

Nedenfor anføres resultatet af undersøgelserne med tilhørende fortolkninger og beregnede niveauer for kalkoverflade o. s. v. i lighed med Herstedøster.

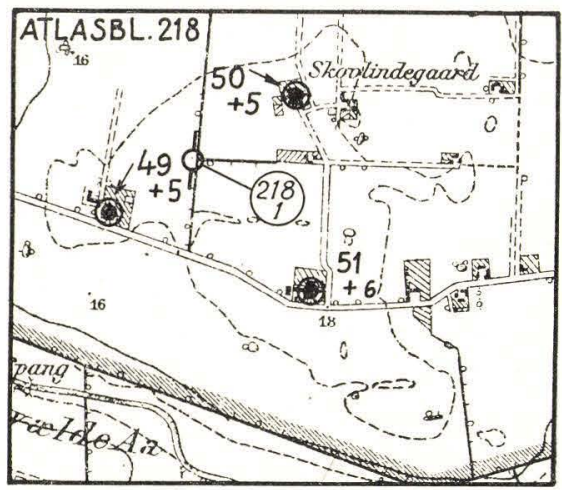

Fig. 12. Lille Linde. Punktprofil nr. 281.1 med omkringliggende boringer (nr. 49-51) og kotetal for danskekalkens overflade ( $m$ over havet). Autoriseret reproduktion efter Geodætisk Institut M. 3628. 1:20000.

Location of electrical drilling no. 218.1, and adjacent wells with corresponding elevations of top of Danian limestone (metres above sea level). Scale 1:20 000 .

Lille Linde.

Punktprofil 218.1. Lille Linde. Ca. $240 \mathrm{~m}$ SV for Skovlindegård.

Terræn ca. +18 m. Målelinie ca. N-S. 20/2 1953. (Fig. 12. Tavle I, fig. 2).

Dybde $\quad \varrho(\Omega \mathrm{m}) \quad$ Fortolkning: $\quad$ Beregnede niveauer. Dybde (ca.)

$0-0,3 \mathrm{~m}$

335 Muld

$0,3-1,6 \mathrm{~m}$

$1,6-6,8 \mathrm{~m}$

47 \5,2 $\}$ Kvartær (moræneler) $4.5-5 \mathrm{~m}$ Grundvandspejl

$6,8-120 \mathrm{~m}$

129 Bryozokalk og skrivekridt

$120-m$

6,1 Skrivekridt med saltvand

$5-6 \mathrm{~m}$ Bryozokalkoverflade

$83 \mathrm{~m}$ Skrivekridtoverflade 


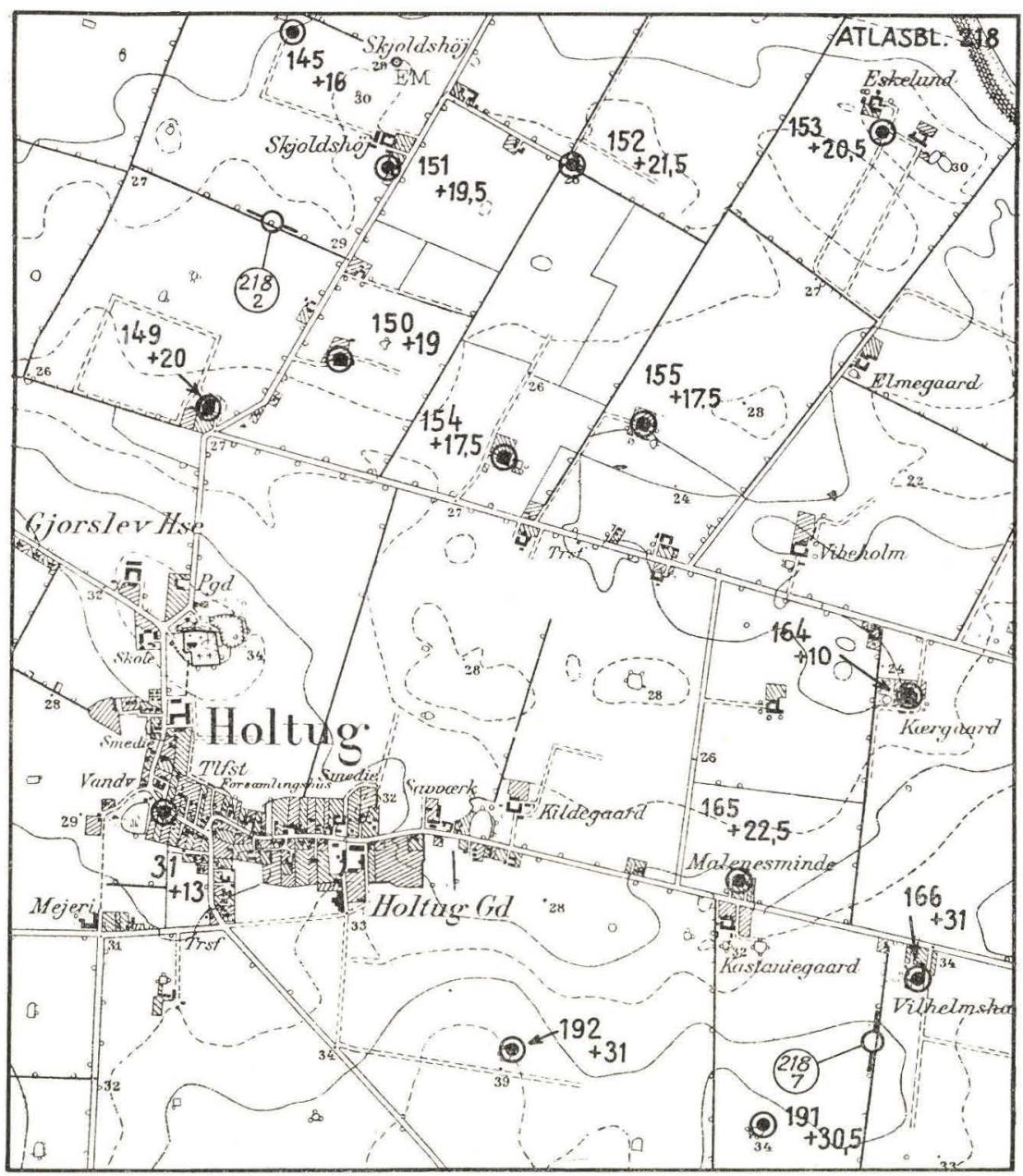

Fig. 13. Holtug. Beliggenhed af punktprofiler (indkredsede numre) og boringer. Kotetal ved boringerne: danskekalkens overflade i $\mathrm{m}$ over havet. Autoriseret reproduktion efter Geodætisk Institut M. 3629. 1:20 000.

Location of electrical drillings (encircled file numbers) and wells with corresponding file numbers and elevation of top of Danian limestone (metres a.s.1.). Scale $1: 20000$.

\section{Stevns.}

Punktprofil 218.2. Holtug I. $300 \mathrm{~m} \mathrm{SV}$ til V for Skjoldshøj. Terræn ca. + 28 m. Målelinie ca. VNV_ØSØ. 21/2 1953. (Fig. 13. Tavle I, fig. 3).

Dybde $\quad \varrho(\Omega \mathrm{m})$ Fortolkning: Beregnede niveauer. Dybde (ca.)

$\begin{array}{rrl}0-0,5 \mathrm{~m} & 185 & \text { Muld } \\ 0,5-0,8 \mathrm{~m} & 203 & \text { Sand } \\ 0,8-6,8 \mathrm{~m} & 54,8 & \text { Ler }\} \text { Kvartær } \\ 6,8-64 \mathrm{~m} & 128,5 & \begin{array}{l}\text { Bryozokalk og } \\ \text { skrivekridt }\end{array} \\ 64-? \mathrm{~m} & 32,5 & \begin{array}{l}\text { Skrivekridt med } \\ \text { saltholdigt vand }\end{array}\end{array}$

$9 \mathrm{~m}$ Bryozokalkoverflade

$12 \mathrm{~m}$ Grundvandspejl

$20 \mathrm{~m}$ Skrivekridt 


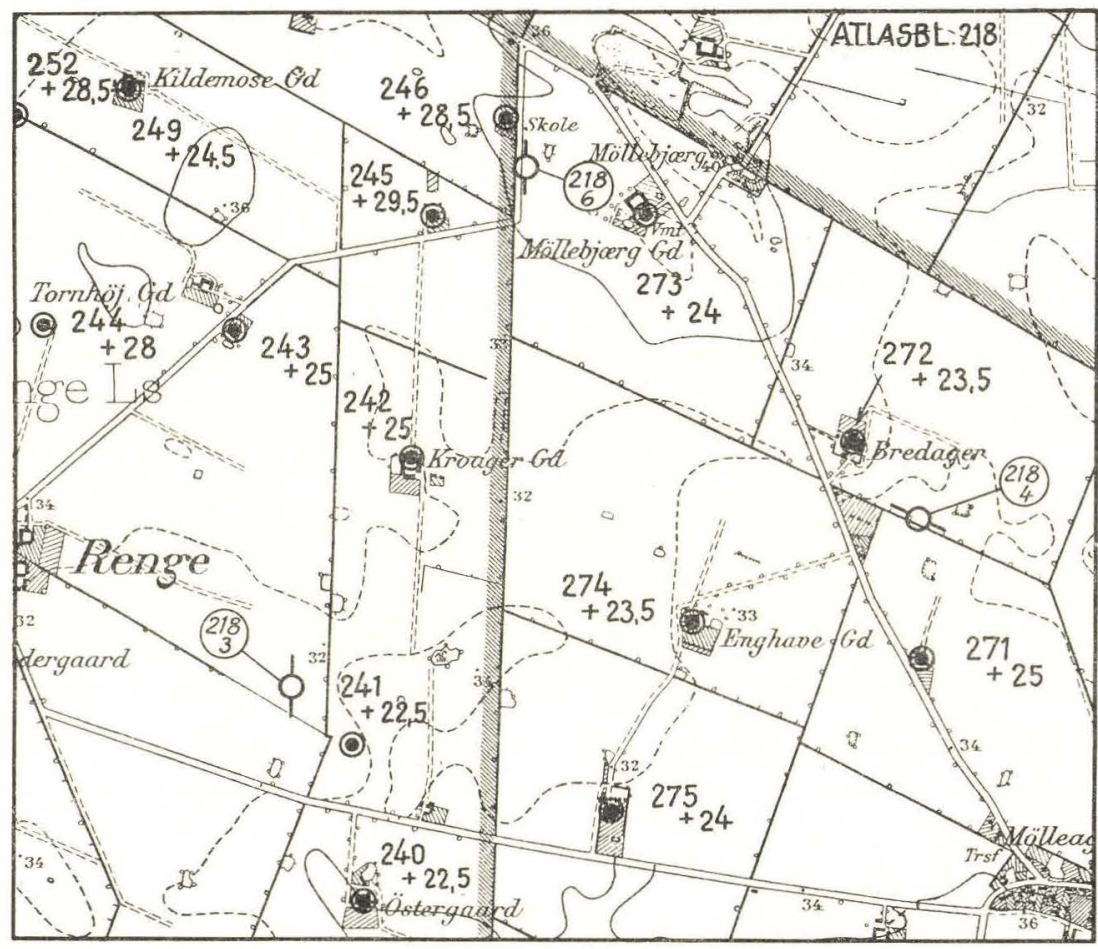

Fig. 14. Renge. Forklaring se fig. 13.

Autoriseret reproduktion efter Geodætisk Institut M. 3729. 1:20000.

(Explanation see fig. 13).

Punktprofil 218.3. Renge Østergård. $450 \mathrm{~m}$ NNV f. Ostergárd. Terræn ca. +32 m. Målelinie N-S. $23 / 2$ 1953. (Fig. 14. Tavle I fig. 4).

\begin{tabular}{|c|c|c|c|}
\hline Dybde & $\varrho(\Omega \mathrm{m})$ & Fortolkning: & Beregnede niveauer. Dybde (ca.) \\
\hline $0-0,5 \mathrm{~m}$ & 78 & Muld & \\
\hline $0,5-1,8 \mathrm{~m}$ & $46,7)$ & Kyortor (mormeler) & \\
\hline $1,8-10 \mathrm{~m}$ & $49\}$ & Avartær (moræneler) & $8 \mathrm{~m}$ Grundvandspejl \\
\hline $10-70 \mathrm{~m}$ & 277 & $\begin{array}{l}\text { Bryozokalk og } \\
\text { skrivekridt }\end{array}$ & $9 \mathrm{~m}$ Bryozokalkoverflade \\
\hline $70-? \mathrm{~m}$ & 36,3 & $\begin{array}{l}\text { Skrivekridt med } \\
\text { saltholdigt vand }\end{array}$ & $42 \mathrm{~m}$ Skrivekridtoverflade \\
\hline
\end{tabular}

Punktprofil 218.4. Højerup. Ca. $200 \mathrm{~m}$ SØ for Bredager.

Terræn ca. +33 m. Målelinie VNV-ØSØ. 24/2 1953. (Fig. 14. Tavle I, fig. 5).
Dybde
$\varrho(\Omega \mathrm{m})$
Fortolkning:
Beregnede niveauer. Dybde (ca.)
$0-0,8 \mathrm{~m}$
$0,8-2,9 \mathrm{~m}$
$2,9-5,7 \mathrm{~m}$
$5,7-80 \mathrm{~m}$
$80-? \mathrm{~m}$
215 Muld
53,7 Kvartær (moræneler)
201 Kvartær (sand?)
233 Bryozokalk og skrivekridt
$9 \mathrm{~m}\left\{\begin{array}{l}\text { Grundvandspejl } \\ \text { Bryozokalkoverflade }\end{array}\right.$

5,55 Skrivekridt med saltvand

$28 \mathrm{~m}$ Skrivekridt 


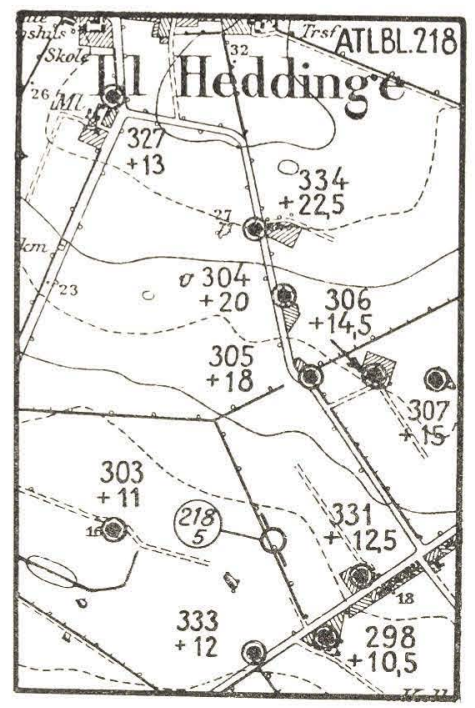

Fig. 15. Lille Heddinge. Forklaring se fig. 13. Autoriseret reproduktion efter Geodætisk Institut M. 3729. 1:20 000. (Explanation see fig. 13).

Punktprofil 218.5. Lille Heddinge. Ca. $1 \mathrm{~km} \mathrm{~N}$ for Korsnæb ved Ellekærgård.

Terræn ca. +17 m. Målelinie ca. NNV—SSØ. 25/2 1953. (Fig. 15. Tavle I, fig. 6).

Dybde $\quad \varrho(\Omega \mathrm{m}) \quad$ Fortolkning: $\quad$ Beregnede niveauer. Dybde (ca.)

$0-0,8 \mathrm{~m} \quad 177 \quad$ Muld o. lign.

$0,8-4 \quad \mathrm{~m} \quad 39 \quad$ Kvartær (moræneler)

$4-10 \mathrm{~m} \quad 226 \quad$ Bryozokalk over

$10-74 \mathrm{~m}$ grundvandspejlet $\quad 5 \mathrm{~m}$ Bryozokalkoverflade

Bryozokalk og

$10 \mathrm{~m}$ Grundvandspejl

skrivekridt under

$25 \mathrm{~m}$ Skrivekridtoverflade

$74-? \mathrm{~m}$ grundvandspejlet

8,8 Skrivekridt med

saltvand

Punktprofil 218.6. Højerup. Ca. $80 \mathrm{~m} \mathrm{~S}$ for skolen ved Møllebjerg Gård. Terræn ca. $+35,5 \mathrm{~m}$. Måleline ea. N-S på østsiden af vejen. 25/2 1953. (Fig. 14. Tavle I, fig. 7).

$\begin{array}{crll}\text { Dybde } & \varrho(\Omega \mathrm{m}) & \text { Fortolkning: } & \text { Beregnede niveauer. Dybde (ca.) } \\ 0-0,4 \mathrm{~m} & 162 & \text { Muld o. lign. } & \\ 0,4-0,6 \mathrm{~m} & 243 & \text { Muld o. lign. } & \\ 0,6-6,8 \mathrm{~m} & 63 & \text { Kvartær (moræneler) } & \\ 6,8-7,2 \mathrm{~m} & 198 & & 6,5 \mathrm{~m} \text { Bryozokalkoverflade } \\ 7,2-11 \mathrm{~m} & 272 & \text { Bryozokalk og } & 10,5 \mathrm{~m} \text { Grundvandspejl } \\ 11-17 \mathrm{~m} & 276 & \text { skrivekridt } & \\ 17-60 \mathrm{~m} & 280 & & \\ 60-? \mathrm{~m} & 66 & \text { Skrivekridt med } & \\ & & & \\ & & & \end{array}$


Punktprofil 218.7. Holtug II. Ca. $150 \mathrm{~m}$ SSV for Vilhelmshåb.

Terræn ca. $+35 \mathrm{~m}$. Målelinie ca. $\mathrm{N}-\mathrm{S}$ langs hegnet ca. $50 \mathrm{~m}$ vest for gården. 26/2 1953. (Fig. 13. Tavle I, fig. 8).

\begin{tabular}{|c|c|c|c|}
\hline Dybde & $\varrho(\Omega \mathrm{m})$ & Fortolkning: & Beregnede niveauer. Dybde (ca.) \\
\hline $0-0,4 \mathrm{~m}$ & 185 & Muld & \\
\hline $0,4-4 \mathrm{~m}$ & 53,7 & Kvartær (moræneler) & \\
\hline $4-14,5 \mathrm{~m}$ & 323 & $\begin{array}{l}\text { Bryozokalk over } \\
\text { grundvandspejlet }\end{array}$ & $4 \mathrm{~m}$ Bryozokalkoverflade \\
\hline $14,5-20,5 \mathrm{~m}$ & 260 & $\begin{array}{l}\text { Bryozokalk under } \\
\text { grundvandspejlet }\end{array}$ & 16 m Grundvandspejl \\
\hline $20,5-43 \mathrm{~m}$ & 208 & $\begin{array}{l}\text { Bryozokalk og } \\
\text { skrivekridt }\end{array}$ & $28 \mathrm{~m}$ Skrivekridtoverflade \\
\hline $43-? \mathrm{~m}$ & 21 & $\begin{array}{l}\text { Skrivekridt med } \\
\text { saltvand }\end{array}$ & \\
\hline
\end{tabular}

Resultatet af målingerne ved Lille Linde og på Stevns er således, at der øjensynlig er tilstrækkelig forskel mellem morænens og kalkens modstande, til at man med ret god tilnærmelse kan beregne dybden for kalkens overflade, ligesom det i enkelte tilfælde er muligt at beregne grundvandspejlets beliggenhed, når vandet ikke står under tryk i kalken. Ved en nærmere betragtning er det ikke særligt påfaldende, at grundvandspejlsniveauet ikke kan erkendes ved hjælp af modstandskurven, når vandet i kalken står under tryk. Findes der i sidste tilfælde moræneler eller andre vandstandsende aflejringer over kalken, er dette nemlig ensbetydende med, at grundvandspejlet kun er et teoretisk vandspejl, som ikke kan erkendes i lagene over kalken som nogen skarp diskontinuitetsflade. Er der tale om leraflejringer, må man således regne med, at de i elektrisk henseende i de fleste tilfælde formodentlig må reagere nogenlunde på samme måde over og under det beregnede grundvandspejl på grund af porevandet i leret, forudsat at de petrografiske forhold er ens.

Modstanden synes ikke at forandre sig mærkbar ved dybder, som kan sættes i relation til overgangen mellem bryozokalk og skrivekridt ${ }^{1}$ ). Dette må føre til konklusionen, at disse bjergarters elektriske modstande er af samme størrelsesorden.

Det kraftige fald i modstandsværdierne, som indfinder sig i en vis dybde svarende til niveauer i skrivekridtet, kan formodentlig kun forklares ved tilstedeværelsen af salt grundvand. Der synes ikke at være nogen anden mulighed for en så gennemgribende ændring af skrivekridtets modstand. I lithologisk henseende måtte man kræve en overgang som f. eks. fra kalk til typisk ler for at en modstandsændring af den observerede størrelsesorden kunne fremkomme. For en sådan antagelse synes der bl. a. ikke at være holdepunkter i de foreliggende tilfælde, når man tager i betragtning, at vor formodning om, at der i de pågældende dybder findes

$\left.{ }^{1}\right)$ Der ses her bort fra Cerithiumkalk og Fiskeler, idet disses indflydelse på modstanden formodentlig er minimal. 
skrivekridt i den almindelige udvikling, er overordentlig velbegrundet.

Antagelsen af saltvandets tilstedeværelse i de dybere dele af skrivekridtet må betragtes som ret velfunderet, idet der er konstateret saltvand i adskillige boringer i egnen (se bl. a. undersøgelsen ved Karise omtalt nedenfor).

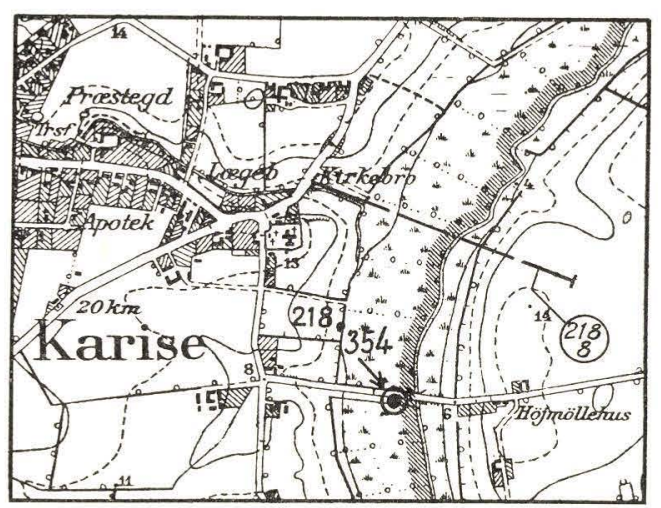

Fig. 16. Karise. Linieprofil 218.8 og boring 218.354. Autoriseret reproduktion efter Geodætisk Institut M 3728. 1:20000.

Location of trenching no. 218.8 and well no. 218.354. Scale $1: 20000$.

Karise. Linieprofil 218.8. Linie fra Kirkebro ( $\mathrm{N}$ for vandløbet) over Stevns A, retning ca. VNV_ØSØ. Elektrodeafstand $10 \mathrm{~m}$, længde $560 \mathrm{~m}$. $26-27 / 2$ 1953. (Fig. 16-17).

Linieprofilet viste ved Kirkebro og $\varnothing$ for Stevns $\AA$ tilsyneladende specifike modstande på gennemsnitlig ca. 90-100 ohmmeter, medens der måltes en minimumsværdi på 35,1 ohmmeter $10 \mathrm{~m}$ øst for åen.

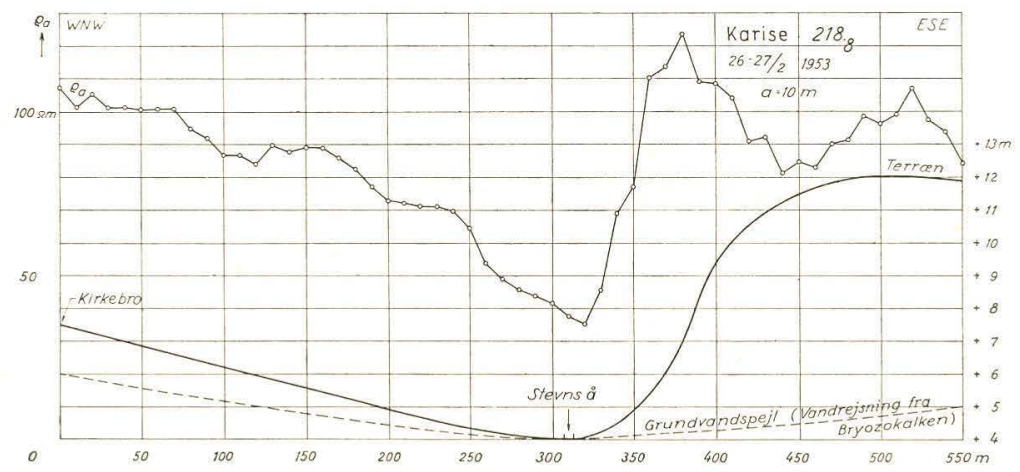

Fig. 17. Karise. Apparent resistivities obtained along the traverse line from Kirkebro towards ESE, $a=10 \mathrm{~m}$. Ground elevation (Terræn) and groundwater table (Grundvandspejl) of the water in the Bryozoan limestone shown in metres a.s.l. 
Ifølge den geologiske kortlægning (V. MiLthers 1908) består jordlagene under muldlaget i måleterrænet fortrinsvis af moræneler.

Ca. $360 \mathrm{~m} \mathrm{~S}$ til $\mathrm{V}$ for målelinien er der udført en boring $\mathrm{S}$ for KariseJuellinge vejen, ca. $60 \mathrm{~m} \mathrm{~V}$ for Stevns $\AA$ (fig. 16), hvorfra der bl. a. foreligger følgende oplysninger:

Arkiv nr. 218.354. Karise.

Kobenhavns VANDForsynings boring nr. 985, udført september 1949.

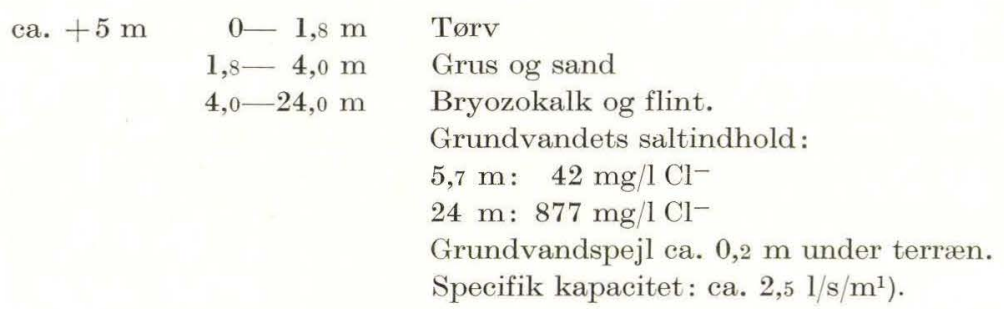

Efter boreprofilet for denne og omkringliggende boringer findes bryozokalkens overflade omkring kote ca. 0 mellem Karise og Juellinge. I ådalen ligger terrænet ved ca. $+4-+5 \mathrm{~m}$ på en strækning af ca. $200 \mathrm{~m}$ af målelinien, liniens endepunkt ved Kirkebro ligger ved ca. $+7,5 \mathrm{~m} \mathrm{og}$ det sydvestlige endepunkt ved ca. $+12 \mathrm{~m}$.

Med en elektrodeafstand på $10 \mathrm{~m}$ skulle en del af bryozokalken omfattes af målingen i ådalen. Efter erfaringerne fra punktprofilerne på Stevns, hvor bryozokalkens modstand under grundvandspejlet beregnedes til mellem $100 \mathrm{og} 260 \mathrm{ohmmeter}$, skulle man vente relativt høje modstande i ådalen, hvor kalken må formodes i ret ringe dybde.

Når resultaterne af den geoelektriske opmåling imidlertid har vist, at der er ringe modstand ved åen til en dybde af ca. $10 \mathrm{~m}$, ligger det nær at sætte dette forhold i forbindelse med, at kalken tydeligvis fører en del saltvand (jfr. boring 218.354). Der er ingen tvivl om, at dette saltvand stammer fra den dybere undergrund. Fra andre egne af landet ved man, at saltvand af denne oprindelse har en tendens til at strømme frem til overfladen i lavtliggende terræn, som i ådalen ved Karise, hvor letgennemtrængelige vandførende lag bevirker en god afstrømning af grundvand og en samtidig lokal sænkning af grundvandspejlet.

3. Langstrup. Efter tidligere undersøgelser (SORGENFREI 1945) ved man, at der igennem Langstrup mose løber en forkastning i danskekalken. Nord for denne findes kalkoverfladen i kote ca. $-60 \mathrm{~m}$, og syd for forkastningslinien stiger kalkoverfladen forholdsvis hurtigt til mellem kote $-40 \mathrm{og}-30 \mathrm{~m}$. I den højtliggende kalk syd for forkastningslinien

1) $1 / \mathrm{s} / \mathrm{m}=$ liter per sekund pr. $\mathrm{m}$ sænkning af grundvandspejlet under pumpning. 
foregår øjensynlig en opstigning af saltvand fra den dybere undergrund igennem et forholdsvis begrænset spaltesystem parallelt med hovedforkastningslinien. Grundvandspejlet ligger over terræn i de talrige boringer, som er udført i området af borefirmaet R. Christiansen for Gentofte kommune.

Langstrup mose blev valgt som forsøgsområde til den første større linieprofilopmåling. Formålet var at få undersøgt, om det var muligt at konstatere forkastningens tilstedeværelse og saltvandets udbredelse ved hjælp af denne metode. Det var endvidere hensigten at opmåle punktprofiler på udvalgte steder, idet man her ikke behøvede at regne med muligheden af en særlig stærkt slørende indvirkning af lag over grundvandspejlet, da vandspejlet $\mathrm{i}$ boringerne ligger over terræn.

Der måltes et par punktprofiler og en række linieprofiler med $a=25 \mathrm{~m}$, $a=33 \mathrm{~m}$ og $a=50 \mathrm{~m}$ (fig. 18).

De anvendte $a$-værdier har tydeligvis ikke medført, at tilstrækkeligt store partier af kalken er blevet inddraget i målingerne. Forkastningen er således ikke aftegnet i kurvebillederne på de konstruerede kurvekort (fig. 19-21).

Omkring boringen med det højeste kloridindhold (187.97) er der ved alle målinger konstateret lave modstandsværdier. Der er en smuk overensstemmelse mellem området med lave modstande og det i 1945 bestemte område med fremtrængende saltvand. Der kan således ikke herske tvivl om, at den større ledningsevne skyldes saltvandet, idet de kvartære lag indeholder en hel del sand, som ellers burde bevirke en stor modstand.

Det er muligt, at man ved et nyt detailstudium af områdets geologi vil kunne korrelere også mindre lokale variationer i det elektriske anomalibillede med geologiske forhold.

Det er iøvrigt hensigten at supplere undersøgelserne ved at lægge flere linier igennem området, idet man må erkende, at linienettets dækningsgrad er utilstrækkelig, navnlig i den nordlige del af området.

I Langstrup Mose opmåltes 4 punktprofiler (Nr. 187.9-12). De udregnede modstande og dybderne for grænserne mellem modstandsintervallerne anføres nedenfor sammen med en geologisk fortolkning af resultaterne. Beliggenheden fremgår af fig. 18.

Punktprofil 187.9. Langstrup Mose. Ved Gentofte Kommunes boring nr. $22=$ D.G.U. ark.nr. 187.97. Terræn ca. $+5 \mathrm{~m}$. Dobbelt punktprofil målt parallelt med og vinkelret på Langstrup A. 21/3 1953. (Tavle II, fig. 1).

\begin{tabular}{|c|c|c|c|}
\hline Dybde & $\varrho(\Omega \mathrm{m})$ & Fortolkning: & Lag i boring 187.97: \\
\hline $0-1 \mathrm{~m}$ & 132 & Tørv & 0 - $\quad 1,1 \mathrm{~m}$ Muld og rødler \\
\hline $1-7,6 \mathrm{~m}$ & 29 & Ler & $\begin{array}{c}\text { 1,1- 10,0 m Blåler, sten, sand og } \\
\text { diluvialler. }\end{array}$ \\
\hline
\end{tabular}




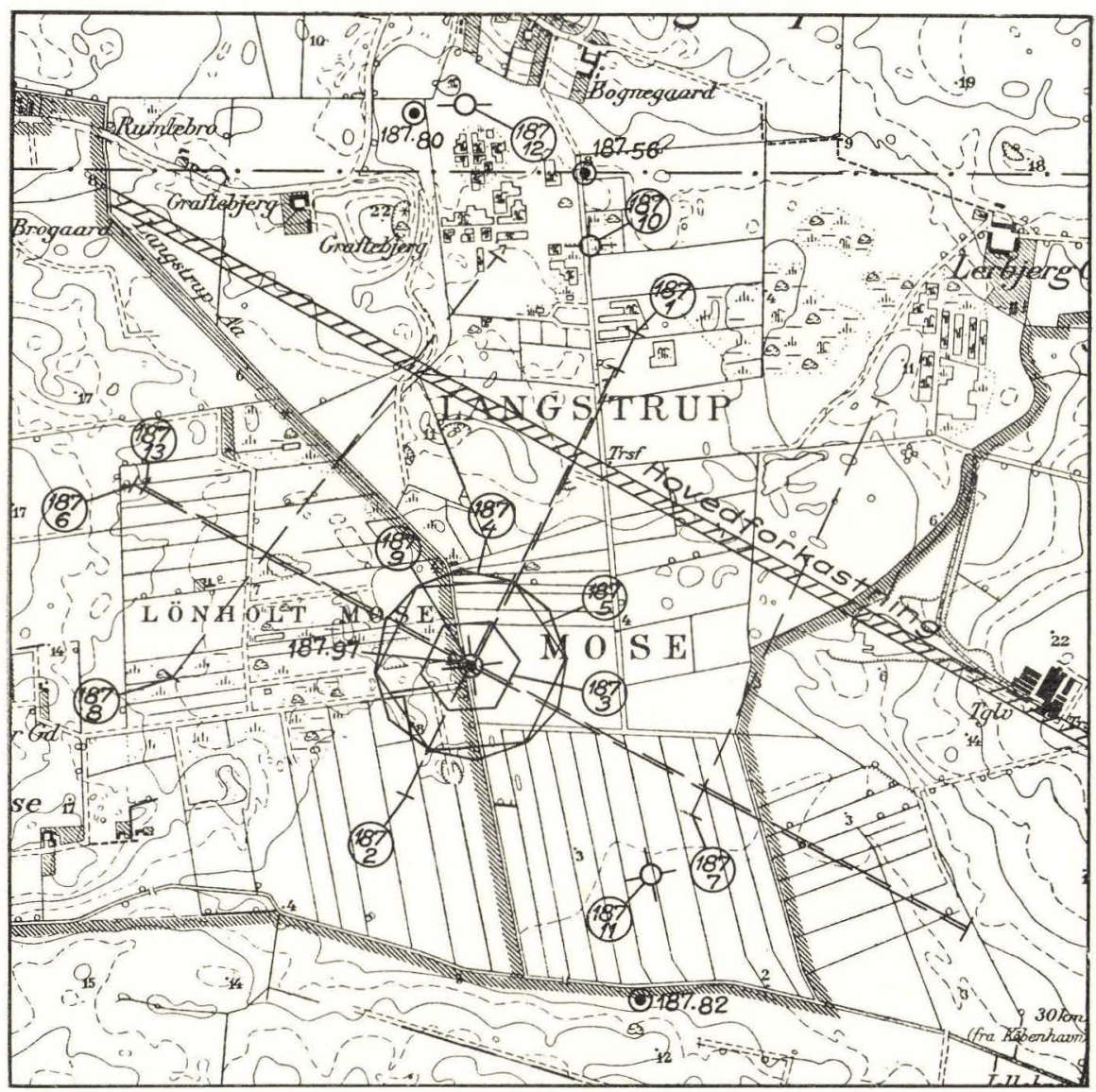

Fig. 18. Langstrup mose. Linieprofiler, punktprofiler (numre i cirkler) og boringer (187. 56,80,82 og 97). Autoriseret reproduktion efter Geodætisk Institut M 2729. 1:20 000. Location of trenching lines, electrical drillings (encireled file numbers) and wells (187. 56,80,82 and 97). Hovedforkastning: main fault in the Danian limestone. Scale 1:20 000.

\begin{tabular}{|c|c|c|c|}
\hline Dybde & $\varrho(\Omega \mathrm{m})$ & Fortolkning: & Lag i boring 187.97: \\
\hline $7,6-40 \mathrm{~m}$ & 48 & Ubestemt kvartær & $\begin{array}{c}10,0-42,3 \mathrm{~m} \text { Diluvialler, blåler o } \\
\text { sten, sand. }\end{array}$ \\
\hline $40-? \mathrm{~m}$ & 132 & Kalksandskalk & 42,3-124,0 m Kalksandskalk. \\
\hline
\end{tabular}

Punktprofil 187.10. Langstrup Mose. Ca. $360 \mathrm{~m} \mathrm{~S}$ for Bognegård i Langstrup og ca. $160 \mathrm{~m} \mathrm{~S}$ for Gentofte Kommunes boring nr. $202=$ D.G.U. ark.nr. 187.56. Dobbelt punktprofil målt ca. N-S og Ø-V. 23/3 1953. Terræn ca. $+7 \mathrm{~m}$. (Tavle II, fig. 2).

\begin{tabular}{|c|c|c|c|}
\hline Dybde & $\varrho(\Omega \mathrm{m})$ & Fortolkning: & Lag i boring 187.56 : \\
\hline $0-0,2 \mathrm{~m}$ & 381 & Tary & $0-2,8 \mathrm{~m}$ Tørv \\
\hline $0,2-0,7 \mathrm{~m}$ & 71 & & \\
\hline
\end{tabular}




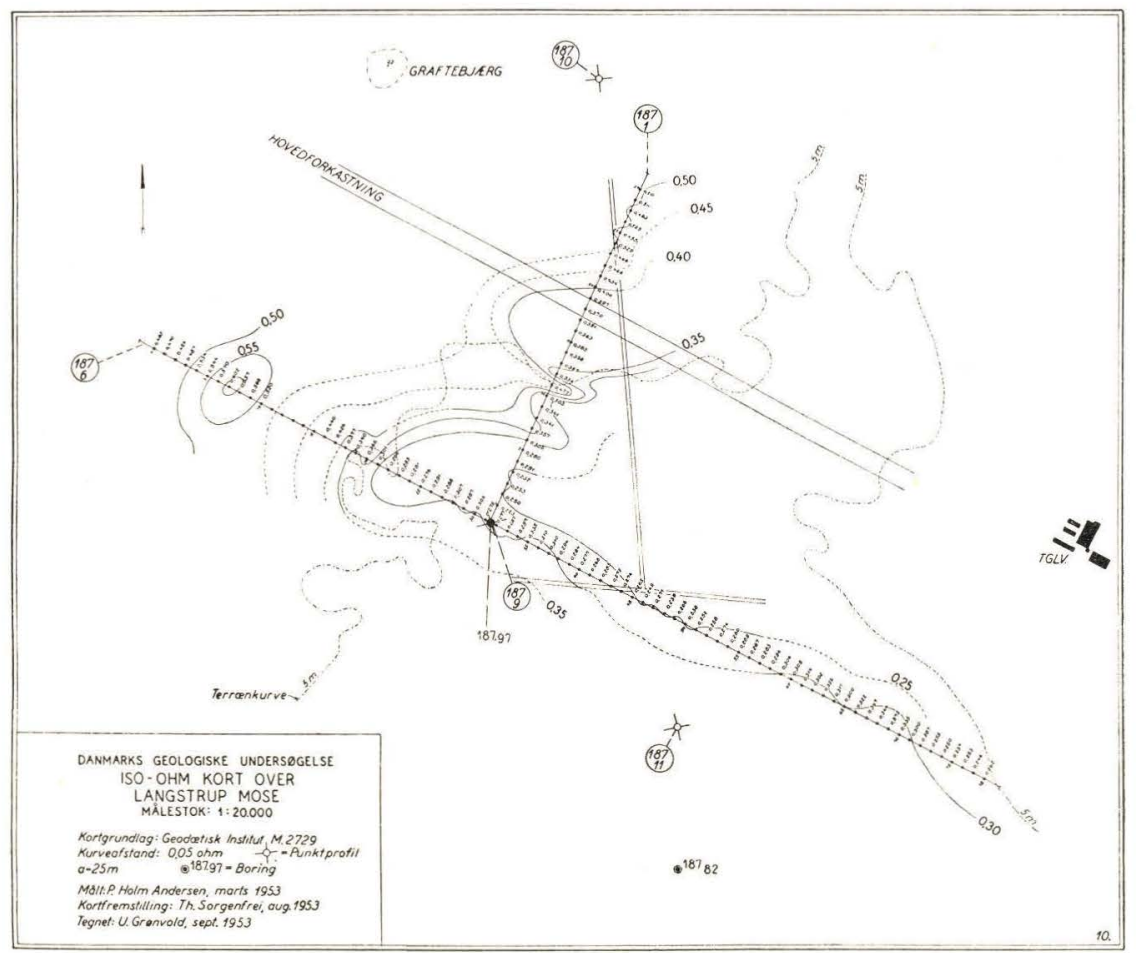

Fig. 19. Langstrup mose. Iso-ohm map, $a=25 \mathrm{~m}$, contour interval $0,05 \Omega$. Scale $1: 20000$.

Dybde

$0,7-0,9 \mathrm{~m}$

$0,9-1,4 \mathrm{~m}$

$1,4-16,5 \mathrm{~m}$

$16,5-73 \mathrm{~m}$

$73-? \mathrm{~m}$
$\varrho(\Omega \mathrm{m}) \quad$ Fortolkning:

19,8 Ler

64,5 Moræne

$\left.\begin{array}{l}81,5 \\ 95\end{array}\right\}$ Sandet kvartær

120 Kalksandskalk
Lag i boring 187.56:

2,8-23,5 m Moræneler

23,5-55,0 m Moræneler, diluvialsand og diluvialler

$55,0-68,4 \mathrm{~m}$ Sand og moræneler 68,4_79,0 m Kalksandskalk

Punktprofil 187.11. Langstrup Mose. Ca. $1720 \mathrm{~m} \mathrm{~S}$ (t. Ø) for Bognegård i Langstrup og ca. $260 \mathrm{~m} \mathrm{~N}$ (t. Ø) for Gentofte Kommunes boring nr. 11, Vejenbrød $=$ D.G.U. ark.nr. 187.82. Dobbelt punktprofil målt ca. NNV—SSØ parallelt med dræningsgrøft og vinkelret herpå. $24 / 3$ 1953. Terræn ca. $+2,5$ m (Tavle II, fig. 3).

$\begin{array}{cclc}\text { Dybde } & \varrho(\Omega \mathrm{m}) \text { Fortolkning: } & \text { Lag i boring 187.82: } \\ 0-0,4 \mathrm{~m} & 66 & \text { Tørv } & 0-1,6 \mathrm{~m} \text { Tørv } \\ 0,4-3,7 \mathrm{~m} & 16,5 \text { Ler } & 1,6-9,6 \mathrm{~m} \text { Diluvialsand og } \\ & & & \text { moræneler. }\end{array}$

$3,7-7,4 \mathrm{~m} \quad 72 \quad$ Leret sand 


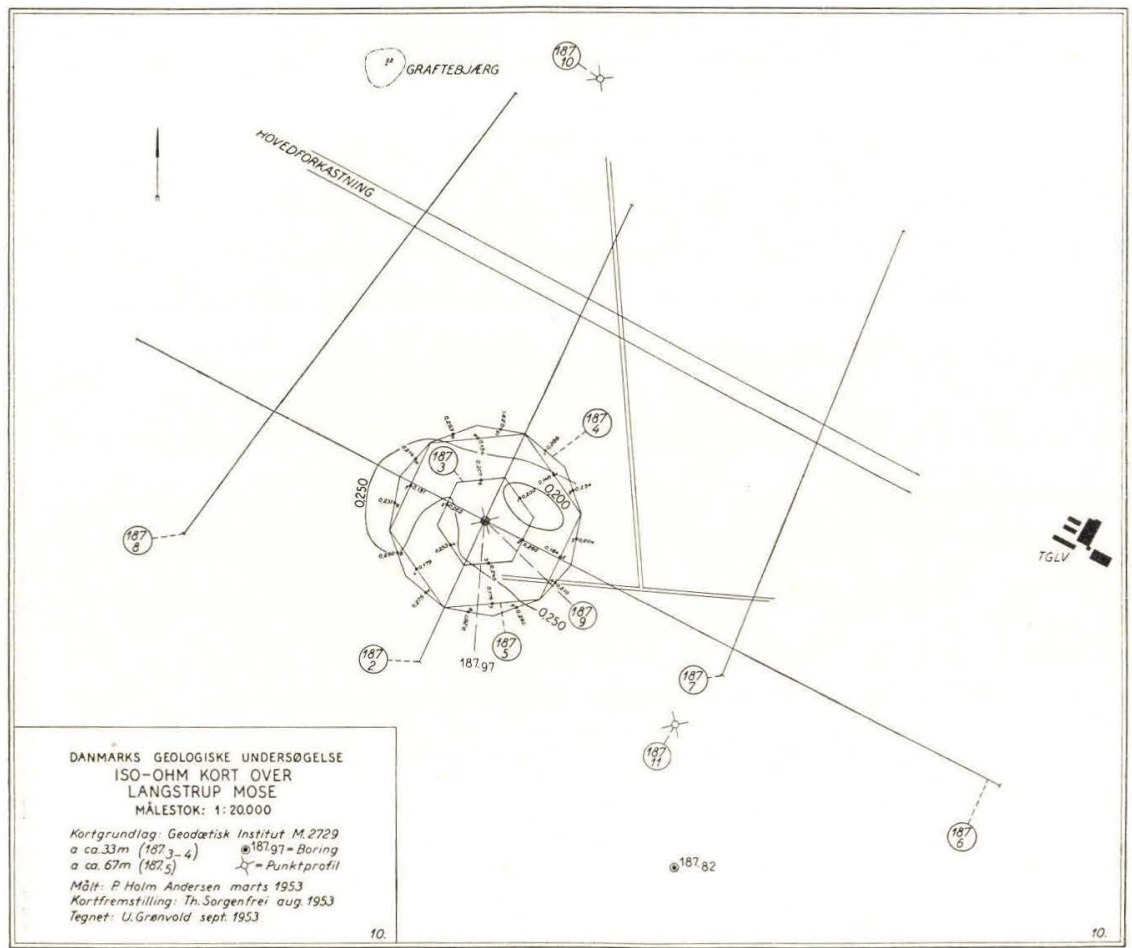

Fig. 20. Langstrup mose. Iso-ohm map, $a=33 \mathrm{~m}$ and $a=67 \mathrm{~m}$, contour interval $(a=33 \mathrm{~m}) 0,05 \Omega$. Scale $1: 20000$.

Dybde

$7,4-36 \mathrm{~m}$

36 -ca. $125 \mathrm{~m}$
$\varrho(\Omega \mathrm{m})$ Fortolkning:

65,5 Fortrinsvis moræneler

$121,5 \quad$ Kalksandskalk
Lag i boring 187.82:

9,6-19,1 m Diluvialsand. 19,1-39,0 m Moræneler. $39,0-53,0 \mathrm{~m}$ Kalksandskalk.

Punktprofil 187.12. Langstrup Mose. Ca. $240 \mathrm{~m} \mathrm{VSV}$ for Bognegård i Langstrup og ca. $100 \mathrm{~m} \varnothing$ for Gentofte Kommunes boring nr. 7, Langstrup = D.G.U. ark.nr. 187.80. Enkelt punktprofil målt ca. Ø-V. 24/3 1953. Terræn ca. $+9 \mathrm{~m}$. (Tavle II, fig. 4 ).

\begin{tabular}{|c|c|c|c|}
\hline Dybde & $\varrho(\Omega \mathrm{m})$ & Fortolkning: & Lag i boring 187.80 : \\
\hline $0-2,4 \mathrm{~m}$ & 41 & Ler & $0-2,8 \mathrm{~m}$ Muld og tørv \\
\hline $2,4-18 \mathrm{~m}$ & 76,2 & & $2,8-4,0 \mathrm{~m}$ Diluvialler \\
\hline $18-($ c. 60$) \mathrm{m}$ & 83 & Ler- og sandlag & $\begin{array}{l}4,0-7,8 \mathrm{~m} \text { Diluvialsand } \\
7,8-18,0 \mathrm{~m} \text { Moræneler }\end{array}$ \\
\hline 60)—? m & 85 & $\begin{array}{l}\text { Sand og kalk- } \\
\text { sandskalk }\end{array}$ & $\begin{array}{c}\text { 18,0-42,5 } \mathrm{m} \text { Moræneler og diluvial- } \\
\text { sand }\end{array}$ \\
\hline & & & $\begin{array}{l}42,5-72,7 \mathrm{~m} \text { Diluvialsand } \\
72,7-74,4 \mathrm{~m} \text { Kalksandskalk }\end{array}$ \\
\hline
\end{tabular}




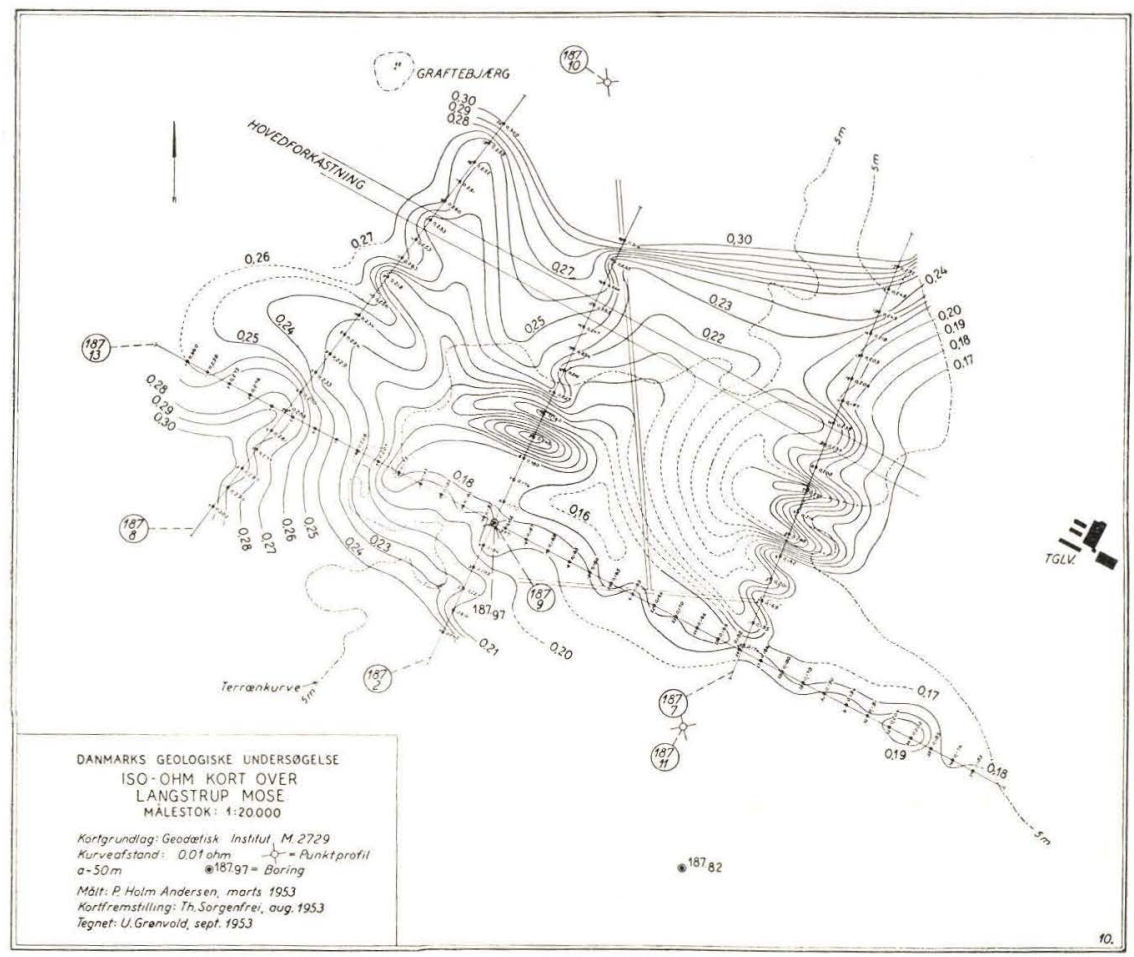

Fig. 21. Langstrup mose. Iso-ohm map, $a=50 \mathrm{~m}$, contour interval $0,01 \Omega$. Scale $1: 20000$.

Resultatet af punktprofilopmålingerne i Langstrup Mose er, at kvartærets sandede zoner øjensynlig giver sig til kende ved relativ høj modstand. Denne anskuelse støttes navnlig ved en nøje sammenligning af boreprofiler og modstandskurver. Forskellen mellem ler- og sandaflejringer udviskes dog øjensynlig enkelte steder. Ved punktprofil 187.9 kunne de lave modstande $\mathrm{i}$ niveauerne svarende til sandlagene $\mathrm{i}$ boring 187.97 forklares ved, at disse lag fører saltvand.

De få iøjnefaldende uoverensstemmelser ved korrelationen i kvartæret af høj modstand= sand og grus og lav modstand=ler ved de forskellige punktprofiler bør iøvrigt ikke overraske, når man dels betænker, at der i de tre af tilfældene er en betydelig afstand mellem boringen og punktprofilet, og dels at kvartærets lagserier erfaringsmæssigt er meget varierende.

Opmålingen synes endvidere at tyde på, at modstandskontrasten mellem kalksandskalken og kvartæret er tilstrækkelig stor ved de tre første punktprofiler til, at kalkoverfladen kan bestemmes med 2-5 m nøjagtighed. Sikkerheden synes at aftage med tiltagende dybde. Den opnåede nøjagtighed ved bestemmelsen af kalkoverfladen er tilfredsstillende i praktisk henseende. 


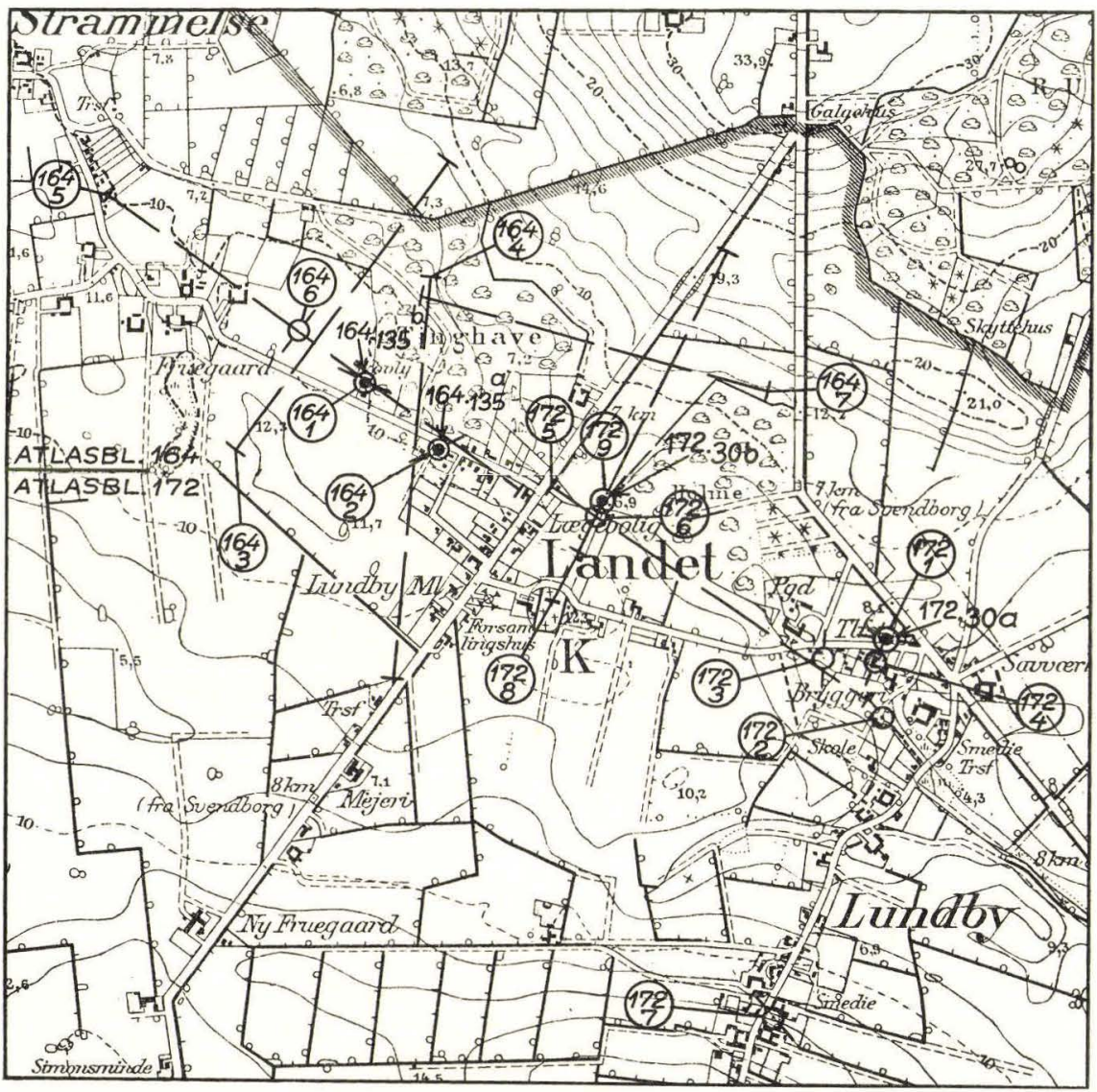

Fig. 22. Landet, Tåsinge. Linieprofiler, punktprofiler (numre i cirkler) og boringer (164.135a og b og 172.30a og b). Autoriseret reproduktion efter Geodætisk Institut, M 4117 og 4217. 1:20000.

Location of trenching lines, electrical drillings (encircled file numbers) and wells (164. 135a and $\mathrm{b}$ and 172.30a and b). Scale 1:20000.

4. Landet, Tåsinge. I forbindelse med undersøgelsesboringer til et vandværk for byerne Lundby, Landet og Strammelse udførtes en større geoelektrisk undersøgelse.

De geologiske forhold på stedet er følgende. Landet, Strammelse og Lundby ligger i et dalstrøg, der strækker sig tværs over Tåsinge i retningen $\mathrm{S} \varnothing-\mathrm{NV}$. Prækvartæret, hvis overflade formodedes at ligge i ca. $40-50$ $\mathrm{m}$ dybde, består af eocænt lillebeltler. Grundvandspejlet ligger meget nær terræn. Dalen er utvivlsomt en tunneldal, opstået under indlandsisen, som dækkede området i sidste istid (V. MiLthers 1948).

I løbet af foråret 1953, udførtes under forfatterens vejledning 3 forgæves boringer i dalen af firmaet Laur. W. Jensen \& Søn, Nakskov. Man traf på moræne uden sandlag eller med ganske underordnede sand- 


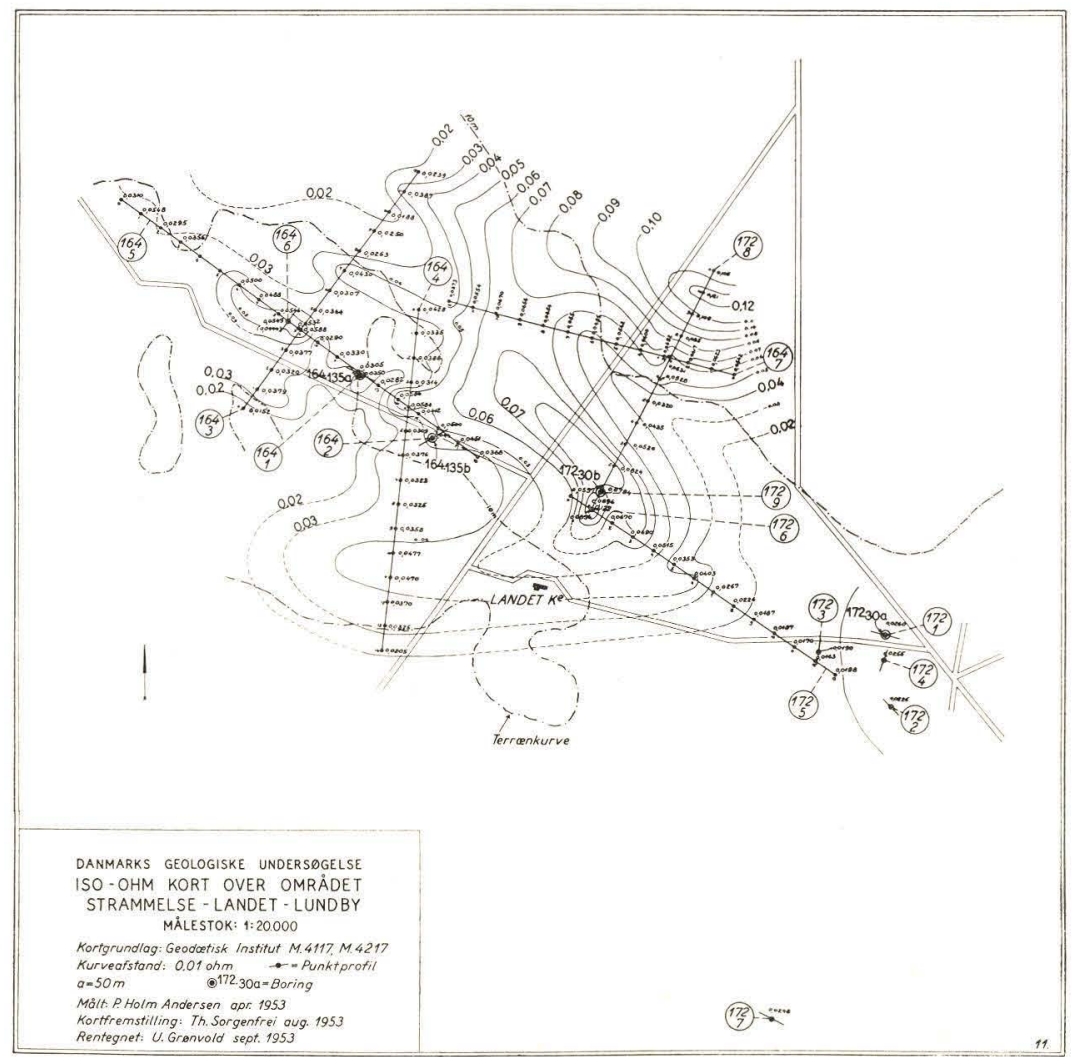

Fig. 23. Landet, Tåsinge. Iso-ohm map, $a=50 \mathrm{~m}$, contour interval $0,01 \Omega$. Scale $1: 20000$.

lag, der ikke havde praktisk betydning med henblik på vandindvinding.

Der blev herefter fra 10/4-22/4 gennemført en geoelektrisk kortlægning ved linieprofiler med $a=50 \mathrm{~m}$, og på borestederne for de forgæves boringer måltes punktprofiler (fig. 22).

Iso-ohm kortet, som udarbejdedes på grundlag af linieopmålingerne fig. 23 viser et forholdsvis udstrakt anomaliområde med store modstandsværdier i den midterste del af dalstrøget, et lavtliggende terræn, hvor dette forhold ikke kan tilskrives lag over grundvandspejlet. Måleværdierne er iøvrigt meget små i langt den største del af dalen. På dalskråningen mod nord ved landevejen Landet-Brejninge findes et andet område med høje modstandsværdier.

De to modstandsmaxima tolkedes som udtryk for sand- og grusforekomster. Dette støttes af resultaterne fra punktprofilerne, som viser små modstande på stederne for de forgæves boringer. Modstandskurverne for punktprofilerne viser iøvrigt et stærkt fald ved elektrodeafstande svarende til dybderne for lillebeltlerets overflade. 
Foruden punktprofilerne ved boringerne måltes profiler på en række andre punkter, hvor forskellige af egnens beboere formodede tilstedeværelsen af vandførende lag. Modstandsværdierne viste sig dog at være lave også på disse steder, hvorfor boringer måtte frarådes.

Efter lokaliseringen af modstandsmaximet $\mathrm{N}$ for Landet kirke anbefaledes en boring i dette område. Målingerne måtte afbrydes på dette tidspunkt på grund af andre arbejder. Ved den siden udførte boring (D.G.U. ark. nr. 172.30.b. se nedenfor) opnåedes et tilfredsstillende resultat i vandindvindingsmæssig henseende. De geoelektriske undersøgelser afsluttedes d. $14-15 / 5$ med opmålingen af et punktprofil ved boringen samt et linieprofil (172.8) igennem boringen, som supplement til de tidligere linier.

Punktprofilernes specifike modstande og tilhørende dybdeintervaller anføres nedenfor sammen med en geologisk fortolkning og oplysninger om jordlagene i boringerne, hvor profil- og borepunkt falder sammen eller ligger nær hinanden. Beliggenhed af linier, punkter og boringer fremgår af fig. 22 .

Punktprofil 164.1. Landet. Boring nr. 2 ved Skovly = D.G.U. ark.nr. 164.135.b. Enkelt punktprofil målt ca. NV—SØ parallelt med vejen LandetStrammelse 10/4 1953. Terræn ca. +10 m. (Tavle III, fig. 1 ).

$\begin{array}{cccc}\text { Dybde } & \varrho(\Omega \mathrm{m}) & \text { Fortolkning: } & \text { Boring 164.135.b. } \\ 0-0,4 \mathrm{~m} & 100 \quad \text { Muld } & 0-0,5 \mathrm{~m} \text { Muld } \\ 0,4-4,2 \mathrm{~m} & 33 \\ 4,2-35 \mathrm{~m} & 25,2\} \text { Moræneler } & 0,5-4,0 \mathrm{~m} \text { Ler, gult } \\ 35-47 \mathrm{~m} & 0,52 \text { Lillebeltler } & 4,0-42 \mathrm{~m} \text { Moræeneler } \\ 47-? \mathrm{~m} & 18,6 \text { Røsnæsler? } & \end{array}$

Punktprofil 164.2. Landet. Boring nr. 1 ca. $200 \mathrm{~m} \mathrm{S \varnothing} \mathrm{for} \mathrm{Skovly} \mathrm{=} \mathrm{D.G.U.}$ ark.nr. 164.135.a. Enkelt punktprofil målt ca. NØ-SV. 11/4 1953. Terræn. ca. +10 m. (Tavle III, fig. 2).

\begin{tabular}{|c|c|c|c|}
\hline Dybde & $\varrho(\Omega \mathrm{m})$ & Fortolkning: & Boring 164.135.a. \\
\hline $0-0,7 \mathrm{~m}$ & 74 & Muld & $0-0,5 \mathrm{~m}$ Muld \\
\hline $0,7-0,8 \mathrm{~m}$ & $18,5)$ & Mormeler & $0,5-3,0 \mathrm{~m}$ Ler, gult \\
\hline $0,8-4,5 \mathrm{~m}$ & $39,4\}$ & norsneter & $3,0-5,0 \mathrm{~m}$ Diluvialsand \\
\hline $4,5-5,6 \mathrm{~m}$ & 48,7 & Moræneler, sandet & $5,0-12,0 \mathrm{~m}$ Moræneler, sandet \\
\hline $5,6-34 \mathrm{~m}$ & 33,7 & Moræneler & 12,0-13,3 m Diluvialsand \\
\hline 34 - ca. $90 \mathrm{~m}$ & 0,68 & $\begin{array}{l}\text { Lillebeltler, Røs- } \\
\text { næesler og Kerte- } \\
\text { mindeler }\end{array}$ & $\begin{aligned} 13,3-42 & \text { m Moræeneler } \\
42-47 & \text { m Lillebeltler }\end{aligned}$ \\
\hline $90-?$ & 152 & Kalk?? & \\
\hline
\end{tabular}

Punktprofil 164.6. Landet-Strammelse. Ca. $180 \mathrm{~m} \mathrm{NV}$ for Skovly i modstandsmaximum. Dobbelt punktprofil målt ca. VNV_- ØS og vinkelret herpå. Terræn ca. $+11 \mathrm{~m}$. (Tavle III, fig. 3). 


$\begin{array}{ccl}\text { Dybde } & \varrho(\Omega \mathrm{m}) & \text { Fortolkning: } \\ 0-3,7 \mathrm{~m} & 250 & \text { Muld } \\ 0,7-3,8 \mathrm{~m} & 27,5 & \text { Moræneler } \\ 3,8-24 \mathrm{~m} & 77 & \text { Sand, grus og ler } \\ 24-27,5 \mathrm{~m} & 3,4 & \text { Lillebeltler og } \\ 27,5-? \mathrm{~m} & 14 & \text { Røsnæsler? }\end{array}$

Punktprofil 172.1. Lundby. Boring nr. 3. ca. $170 \mathrm{~m} \varnothing$ for prestegården = D.G.U. ark.nr. 172.30.a. Enkelt punktprofil målt ca. Ø-V. 13/4 1953. Terræn ca. $+8 \mathrm{~m}$. (Tavle III, fig. 4 ).

\begin{tabular}{|c|c|c|c|}
\hline Dybde & $\varrho(\Omega \mathrm{m})$ & Fortolkning: & Boring 172.30.a. \\
\hline $0-0,6 \mathrm{~m}$ & 175 & Muld & $0-0,5 \mathrm{~m}$ Muld \\
\hline $0,6-0,9 \mathrm{~m}$ & 94,5 & Sandet moræneler & $0,5-4 \mathrm{~m}$ Ler, gult \\
\hline $0,9-7,1 \mathrm{~m}$ & 44,5 & & m Moræeneler \\
\hline $7,1-8,9 \mathrm{~m}$ & $12\}$ & Moræeneler & \\
\hline $8,9-22,0 \mathrm{~m}$ & 20 & & $9-9,5 \mathrm{~m}$ Diluvialsand \\
\hline $22,0-39,0 \mathrm{~m}$ & $4,0)$ & Lillebeltler & $9,5-38,0 \mathrm{~m}$ Fortrinsvis moræneler \\
\hline $39,0-? \mathrm{~m}$ & $9,4\}$ & Linebentier & $38-40,0$ m Røsnæsler \\
\hline
\end{tabular}

Punktprofil 172.2. Lundby. Ca. $200 \mathrm{~m} \mathrm{~S}$ for boring 172.30.a. Enkelt punktprofil målt ca. NV—SØ 14/4 1953. Terræn ca. +4 m. (Tavle III, fig. 5).

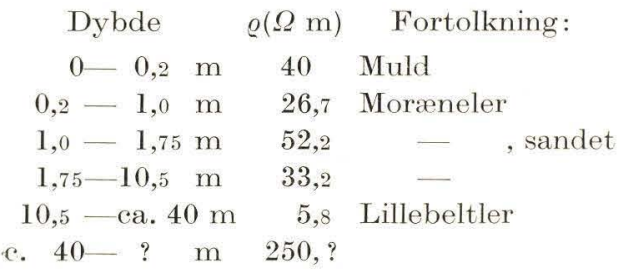

Punktprofil 172.3. Lundby. Ca. $60 \mathrm{~m}$ SØ for præstegården. Enkelt punktprofil målt ca. N-S $15 / 4$ 1953. Terræn ca. $+6 \mathrm{~m}$.

\begin{tabular}{ccl} 
Dybde & $\varrho(\Omega \mathrm{m})$ & \multicolumn{1}{c}{ Fortolkning: } \\
$0-2,4 \mathrm{~m}$ & 31 & Muld og moræneler \\
$2,4-5,4 \mathrm{~m}$ & 93 & Sand \\
$5,4-15,5 \mathrm{~m}$ & 23 & Moræneler \\
$15,5-93 \mathrm{~m}$ & 3,9 & Lillebeltler \\
$93-? \mathrm{~m}$ & $0,24 \quad$ ?
\end{tabular}

Punktprofil 172.4. Lundby. Ca. $70 \mathrm{~m} \mathrm{~S}$ for boring 172.30.a. Enkelt punktprofil målt ca. NNO-SSV 15/4 1953. Terræn ca. +6 m. (Tavle III, fig. 6).

\begin{tabular}{|c|c|c|}
\hline Dybde & $\varrho(\Omega \mathrm{m})$ & Fortolkning: \\
\hline $0-0,5 \mathrm{~m}$ & 37 & \multirow{2}{*}{ Muld og moræneler } \\
\hline $0,5-0,7 \mathrm{~m}$ & ca. 45 & \\
\hline $0,7-9 \mathrm{~m}$ & 28 & \multirow{2}{*}{ Moræeneler } \\
\hline $9--23,5 \mathrm{~m}$ & $17,4\}$ & \\
\hline $3,5-? \mathrm{~m}$ & 3,6 & Lillebeltler \\
\hline
\end{tabular}


Punktprofil 172.6. Landet. Ca. $200 \mathrm{~m}$ NNØ for Landet kirke og ca. $40 \mathrm{~m}$ SSØ for boring nr. $4=$ D.G.U. ark.nr. 172.30.b. Enkelt punktprofil målt ca. NV—SØ. 22/4 1953. Terræn ca. +8 m. (Tavle III, fig. 7).

\begin{tabular}{|c|c|c|}
\hline Dybde & $\varrho(\Omega \mathrm{m})$ & Fortolkning \\
\hline $0-0,5 \mathrm{~m}$ & 137 & Sandmuld \\
\hline $0,5-1,1 \mathrm{~m}$ & 167 & \\
\hline $1,1-2,7 \mathrm{~m}$ & 165 & Sand og grus \\
\hline $2,7-13 \quad \mathrm{~m}$ & 132 & \\
\hline 13 - са. $34 \mathrm{~m}$ & 43,5 & Ler \\
\hline
\end{tabular}

Punktprofil 172.9. Landet. Ca. $240 \mathrm{~m}$ NNØ for Landet kirke ved boring nr. 4 = D.G.U. ark.nr. 172. 30.b. Enkelt punktprofil målt ca. NN Ø SSV. 14/5 1953. Terræn ca. $+6,9 \mathrm{~m}$. (Tavle III, fig. 8 ).

\begin{tabular}{|c|c|c|}
\hline Dybde & $\varrho(\Omega \mathrm{m})$ & Fortolkning: \\
\hline $0-1,5 \mathrm{~m}$ & 24 & Muld og ler \\
\hline $1,5-4,7 \mathrm{~m}$ & 44,8 J & Muld og ler \\
\hline $4,7-12 \mathrm{~m}$ & 105 & Sand og grus \\
\hline $12-25$ & 108 & \\
\hline $25-76$ & 5,3 & $\begin{array}{l}\text { Kvartærler og } \\
\text { Lillebeltler }\end{array}$ \\
\hline $76-?$ & 280 & $?$ \\
\hline
\end{tabular}

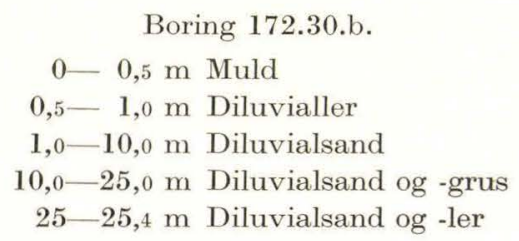

Filter fra $18,4-25,4 \mathrm{~m}$. Vandrejsning til terræn; $10 \mathrm{~m}^{3} / \mathrm{t}$ ved $3 \mathrm{~m}$ sænkning. Specifik kapacitet: $0,9 \mathrm{l} / \mathrm{s} / \mathrm{m}$.

Undersøgelserne ved Landet har vist modstandsmålingers anvendelighed ved lokaliseringen af sand- og grusforekomster i istidsdannelserne her i landet. Af interesse er endvidere påvisningen af Lillebeltlerets lave modstand.

Ved en sammenligning af resultaterne fra boringerne og fra punktprofilopmålingerne viser det sig, at man ved punktprofilerne registrerer Lillebeltleret ved et højere niveau, end det sker i boringerne. Det må dog i denne forbindelse bemærkes, at de geologiske jordartsbetegnelser, som her anvendes ved karakteriseringen af de gennemborede lag, er genetiske. De giver ikke direkte udtryk for jordlagenes lithologiske sammensætning. Boreprøverne af moræneleret fra den nederste del af istidsdannelserne viser, at der findes et betydeligt indhold af eocænt ler. Dette er sikkert forklaringen på, at modstandsværdierne er lave også i den nedre del af morænen, som derved i elektrisk henseende får egenskaber meget nær ved Lillebeltlerets egenskaber.

5. Ängelholm (Skåne). 6-7/5 1953 gennemførtes en geoelektrisk opmåling ved Ängelholm i samarbejde med docent civilingeniør G. WEIJ- 
Man-Hane, Chalmers Tekniska Högskola, Göteborg, som i sin egenskab af docent ved højskolen havde anmodet D.G.U. om at bistå ved en geoelektrisk opmåling og at stille D.G.U.'s resistivitetsmåler til disposition for teknologerne cand. INgVAR Hörberg og cand. KARLAxem KäLLstrand, idet deres eksamensprojekt bl. a. omfattede en geoelektrisk opmåling ved Ängelholm (HörberG \& KäLlStrand 1953). I det følgende skal der gøres rede for undersøgelserne.

De geologiske forhold på Ängelholmssletten er skildret i »Utdrag ur Länsutredningen för vatten- och avloppsledningar inom Kristiansstad Län« af E. Mohrex. Det fremgår heraf, at de øverste jordlag, ca. 20$50 \mathrm{~m}$, består af ishavsler, herunder følger iselvssand og -grus ${ }^{1}$ ), som især har betydning for vandindvindingen. Underlaget for disse aflejringer er morænedannelser, og i ca. 120-130 m dybde følger lag af skifre og sandsten med kullag, som henføres til Rhaet-Lias formationen.

Der blev indhentet oplysninger om de gennemborede lagserier ved Ängelholm vandværks boringer I og II ved St. Brandsvig, hvor opmålingen skulle foregå. Boreprøver fra de to boringer, som opbevaredes på vandværket, blev endvidere undersøgt af forfatteren.

Den geoelektriske opmåling omfattede tre linieprofiler som vist på kortet fig. 24. Linierne 12.1,3 og 4 er målt med $a=50 \mathrm{~m}$. Der er målt et punktprofil (12.2) ved boring II og et dobbelt punktprofil (12.5) ved position 1 på linie 12.4 (tavle II, fig. 5-6).

Kurvekortet fig. 25 viser, at de største modstandsværdier findes omkring boring I (max. $0.272 \mathrm{ohm})$, medens de mindste værdier er målt mod Ø i undersøgelsesfeltet.

Der er ingen tvivl om, at modstandsmaximet står i forbindelse med forekomsten af forholdsvis tykke sand- og gruslag, således som det illustreres ved boreprofilet for boring I (se punktprofil 12.5 nedenfor). Det er vigtigt at bemærke, at sand-og gruslagene ved boring II (se punktprofil 12.2) til trods for deres vandføring, som formodentlig er betydelig, ikke giver sig til kende ved høje modstandsværdier, sammenlignet med området ved boring I. En meget vigtig årsag til dette er uden tvivl, at gruslagene i området omkring boring II har ringere tykkelse og ligger dybere end sand- og gruslagene ved boring I.

Ved de to punktprofiler 12.2 og 12.5 har de øverste jordlag extremt høje modstandsværdier, således at beregningen af de specifike modstande først kan ske efter den stejle del på kurverne.

For punktprofil 12.2 kan man nå til to sæt $\varrho$-værdier, som tager sig således ud:

1) Svarer til de danske betegnelser smeltevandssand og -grus (eller: diluvialsand og -grus). Ved denne og næste undersøgelse anvendes de svenske betegnelser for at undgå begrebsforskydning. 


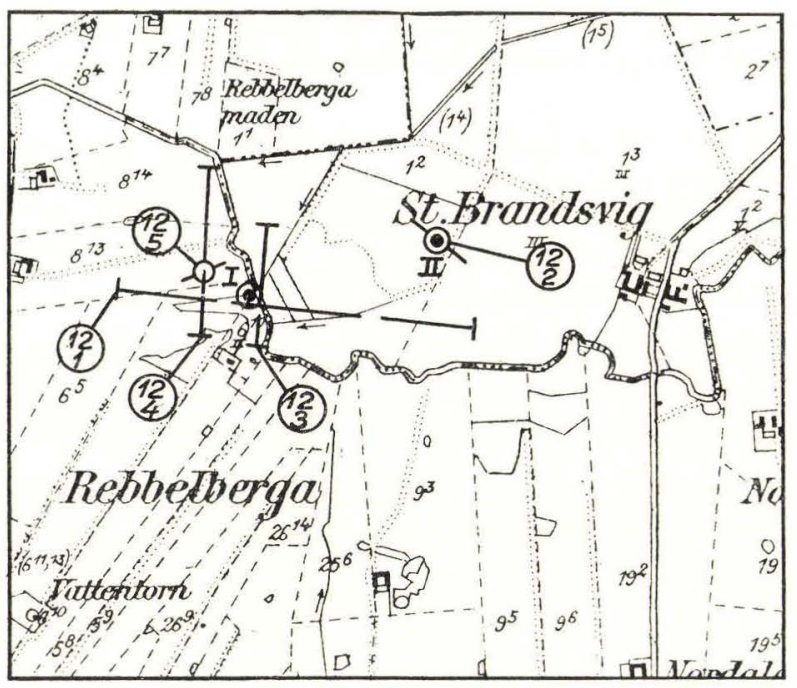

Fig. 24. Ängelholm vandværk, St. Brandsvig. Linieprofiler, punktprofiler (numre i cirkler) og boringer (I-II). Autoriseret reproduktion, Rikets Allmänna Kartverk, Stockholm. Blad 22 Munka-Ljungby. 1:20 000.

Location of trenching lines, electrical drillings (encircled file numbers) and wells (I-II). Scale 1:20000.

Punktprofil 12.2. Ängelholm. Ved boring II, Stora Brandsvig. Målelinie ca. NV-SØ 6/5 1953. Terrænhøjde ukendt. (Tavle II, fig. 5).

A

Dybde $\varrho(\Omega \mathrm{m}) \quad$ Dybde $\varrho(\Omega \mathrm{m})$

$?-2,9 \mathrm{~m} \quad 40 \quad ?-1,8 \mathrm{~m} \quad 38$

$2,9-3,7 \mathrm{~m} \quad 120 \quad 1,8-3,3 \mathrm{~m} \quad 71$

$3,7-5,1 \mathrm{~m} \quad 20 \quad 3,3-4,8 \mathrm{~m} \quad 22$

$5,1-29 \quad \mathrm{~m} \quad 28 \quad 4,8-29 \quad \mathrm{~m} \quad 28$

$29-43 \quad \mathrm{~m} \quad 87 \quad 29-43 \quad \mathrm{~m} \quad 87$

$\begin{array}{lllllll}43-50 & \mathrm{~m} & 12 & 43-50 & \mathrm{~m} & 12\end{array}$

50 - ? m $42 \quad 50$ - ? m 42
Boring II

$$
0-5 \mathrm{~m} \text { Sandet ler }
$$

5-27,7 m Mere eller mindre sandet ler og leret sand

$27,7-32,8 \mathrm{~m}$ Sand og grus

$32,8-36$ m Leret sand og grus

Der er i begge tilfælde forholdsvis god korrelation mellem intervallet med stor modstand fra $29--43 \mathrm{~m} \mathrm{og}$ sandets og grusets optræden under $27,7 \mathrm{~m}$ dybde.

For punktprofil 12.5 er vi nået til følgende modstande og dybder.

Punktprofil 12.5. Ängelholm. Dobbelt punktprofil, ca. $130 \mathrm{~m} \mathrm{NV}$ for boring I, St. Brandsvig. Målelinie ea. NØ-SV og ea. vinkelret herpå 7/5 1953 . Terrænhøjde ukendt. (Tavle II, fig. 6). 


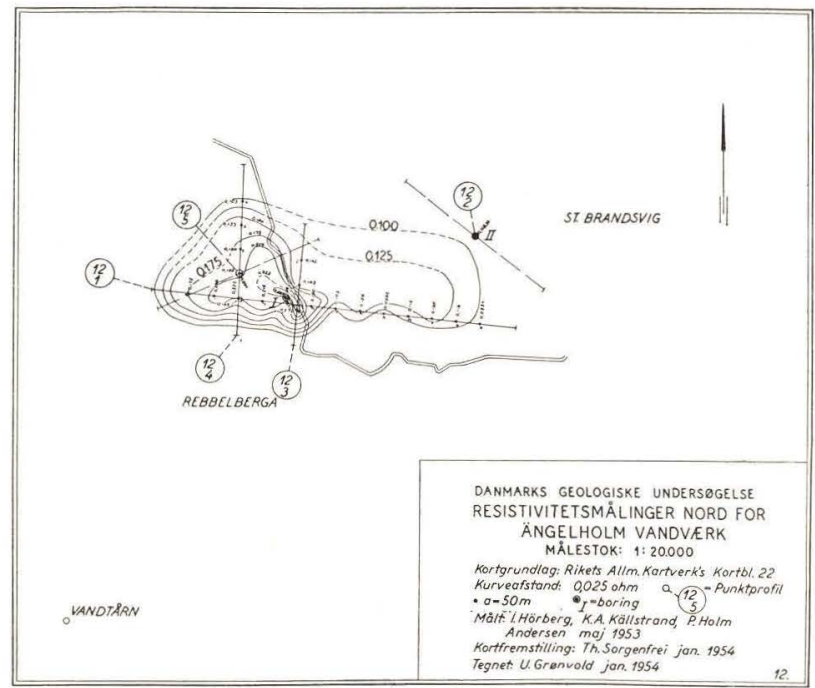

Fig. 25. Ängelholm. Iso-ohm map, $a=50 \mathrm{~m}$, contour interval 0,025 $\Omega$, scale $1: 20000$.

\begin{tabular}{ccl} 
Dybde & $\varrho(\Omega \mathrm{m})$ & \multicolumn{1}{c}{ Fortolkning } \\
$0-0,2 \mathrm{~m}$ & 550 & Sand og grus \\
$0,2-3 \mathrm{~m}$ & 59 & Ler \\
$3-? \mathrm{~m}$ & $60-70 \begin{array}{l}\text { Ler- og sandlag eller } \\
\text { sandet ler }\end{array}$ \\
$(50-100 \mathrm{~m})$ & &
\end{tabular}

Boreprofilet for boring I er anført til sammenligning, men det må erindres, at punkt 12.5 ligger i nogen afstand fra denne boring. Modstandskurven må fortolkes på den måde, at der findes en del sand og grus ved punkt 12.5.

6. Veberöd (Skåne). I fortsættelse af undersøgelserne ved Ängelholm gennemførtes en geoelektrisk opmåling i terrænet ca. $1 \mathrm{~km} \mathrm{~N}$ for Veberöd ved gården Björkhaga (Hörbera \& Käctstrand 1953). Dette skete ligeledes i samarbejde med civilingeniør G. WEIJMAN-HANE og kandidaterne Ingvar Hörberg og KarL-Axel KäLlstrand.

Opgaven gik i dette tilfælde ud på at skaffe sig et bedre overblik over resistivitetsmetodens anvendelighed i det skånske terræn, idet man ved tidligere detaillerede boreundersøgelser havde skaffet sig gode oplysninger om jordbundsforholdene på stedet til en dybde af $10-15 \mathrm{~m}$. I WeIJMAN-HANE's ikke offentliggjorte »Redogörelse för grundvattensundersökningar för Veberöd 1953« findes en oversigt over de geologiske forhold med generaliserede tværprofiler, der støtter sig på resultater fra 


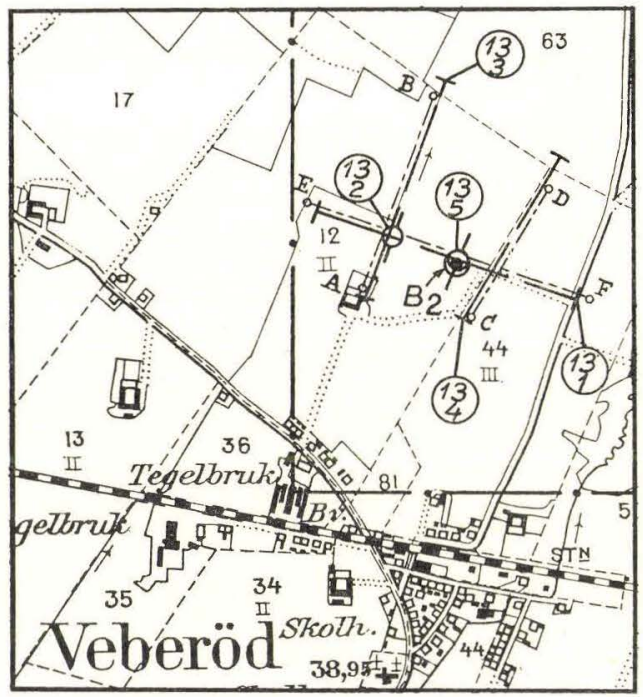

Fig. 26. Veberöd. Linieprofiler, punktprofil (numre i cirkler), boring $B_{2}$ og geologiske profiler $\left(A-B, C-D, E-F^{\prime}\right)$. Autoriseret reproduktion efter Rikets Allmänna Kartverk, Stockholm, Blad Veberöd. 1:20000.

Location of trenching lines, electrical drilling (encircled file numbers) well $B_{2}$ and cross sections $\left(A-B, C-D, E-F^{\prime}\right)$.

slagboringer og vandindvindingsboringer. Et geologisk oversigtskort i 1:50 000 over egnen findes i samme rapport. Det er med hensyn til jordlagenes udbredelsesforhold en gengivelse af det nordøstlige hjørne af S.G.U.'s kortblad Börringe Kloster, Ser. Aa. No. 138.

De geologiske forhold tager sig i store træk således ud: På NØsiden af Romeleåsen er der aflejret glacialdannelser i sidste istid af en indlandsis, som bevægede sig mod NV i et af de senere stadier. De glaciale dannelser omfatter dels iselvsaflejringer og dels moræneaflejringer. Boreundersøgelserne og det geologiske kort viser, at der i undersøgelsesterrænet findes en del sand- og gruslag i nærheden af jordoverfladen. Selv om der ikke har været lejlighed til at se prøver af de gennemborede lag, er der ingen grund til at betvivle, at en del af disse dannelser er ægte iselvsaflejringer, som hviler på (eller måske delvis er indblandet i) moræne. Terrænet er ret jævnt. Med hensyn til prækvartæret findes ingen konkrete oplysninger. Antagelig findes disse lag først under $50 \mathrm{~m}$ dybde.

Den geoelektriske opmåling omfattede tre linieprofiler: 13.1 $(a=15 \mathrm{~m})$ parallelt med en borelinie betegnet $E-F ; 13.3(a=10 \mathrm{~m})$ parallelt med borelinie $A-B$ og $13.4(a=15 \mathrm{~m})$ parallelt med borelinie $C-D$. Desuden måltes to punktprofiler: 13.2 ved skæringspunktet for linierne $A-B$ og $E-F$ og med målelinie parallelt med $A-B$, og 13.5 ved boring $B_{2}$ og med målelinie omtrent vinkelret på $E-F$ (fig. 26). 


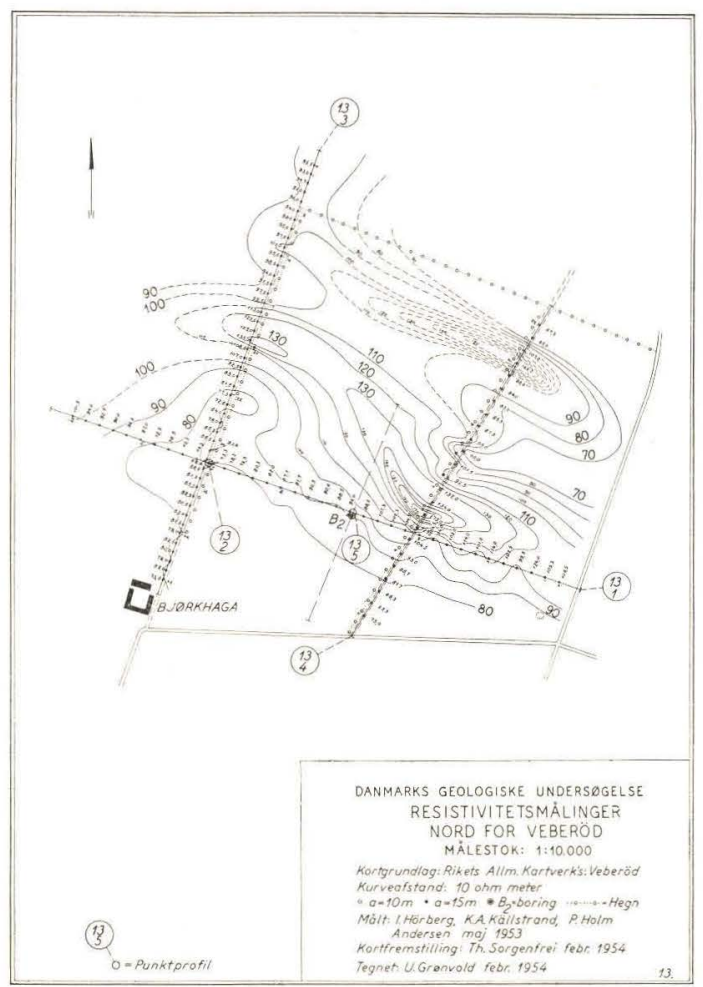

Fig. 27. Veberöd. Equi-Resistivity map, $a=10$ and $a=15 \mathrm{~m}$, contour interval $10 \Omega \mathrm{m}$, scale $1: 10000$.

På grundlag af modstandsværdierne $(R)$ fra linieprofilerne er den tilsyneladende specifike modstand udregnet efter formel (4) side 14, og de således fundne $\varrho$-værdier er indført på kortet fig. 27 ved positionerne på linierne. På grundlag af disse værdier er der tegnet kurver for den tilsyneladende specifike modstand med en kurveafstand på $10 \Omega \mathrm{m}$.

Fortolkning af linieopmålingen. For hver position udtrykker den tilsvarende $\varrho$-værdi et tilnærmet gennemsnit af de specifike modstande i lagene ned til en dybde ca. lig med elektrodeafstanden $a$. De på kortet sammenstillede $\varrho$-værdier er således i virkeligheden ikke absolut indbyrdes sammenlignelige: ved $a=10 \mathrm{~m}$ omfattes færre lag end ved $a=15 \mathrm{~m}$. Værdierne ved linie 13.3. bør således egentlig betragtes særskilt, og man bør ikke bygge for meget på en sammenligning af talværdierne på 13.3 med de to andre liniers talværdier.

Når der til trods for uligheden i måleobjekt er tegnet et kurvebillede, er dette sket ud fra opfattelsen, at man herigennem alligevel vil få et tilnærmet udtryk for reelt forekommende anomalier i området, idet retningen af modstandsgradienten, som afbildes ved kurverne, skulle repræsentere områdets modstandsgradient med god tilnærmelse. 

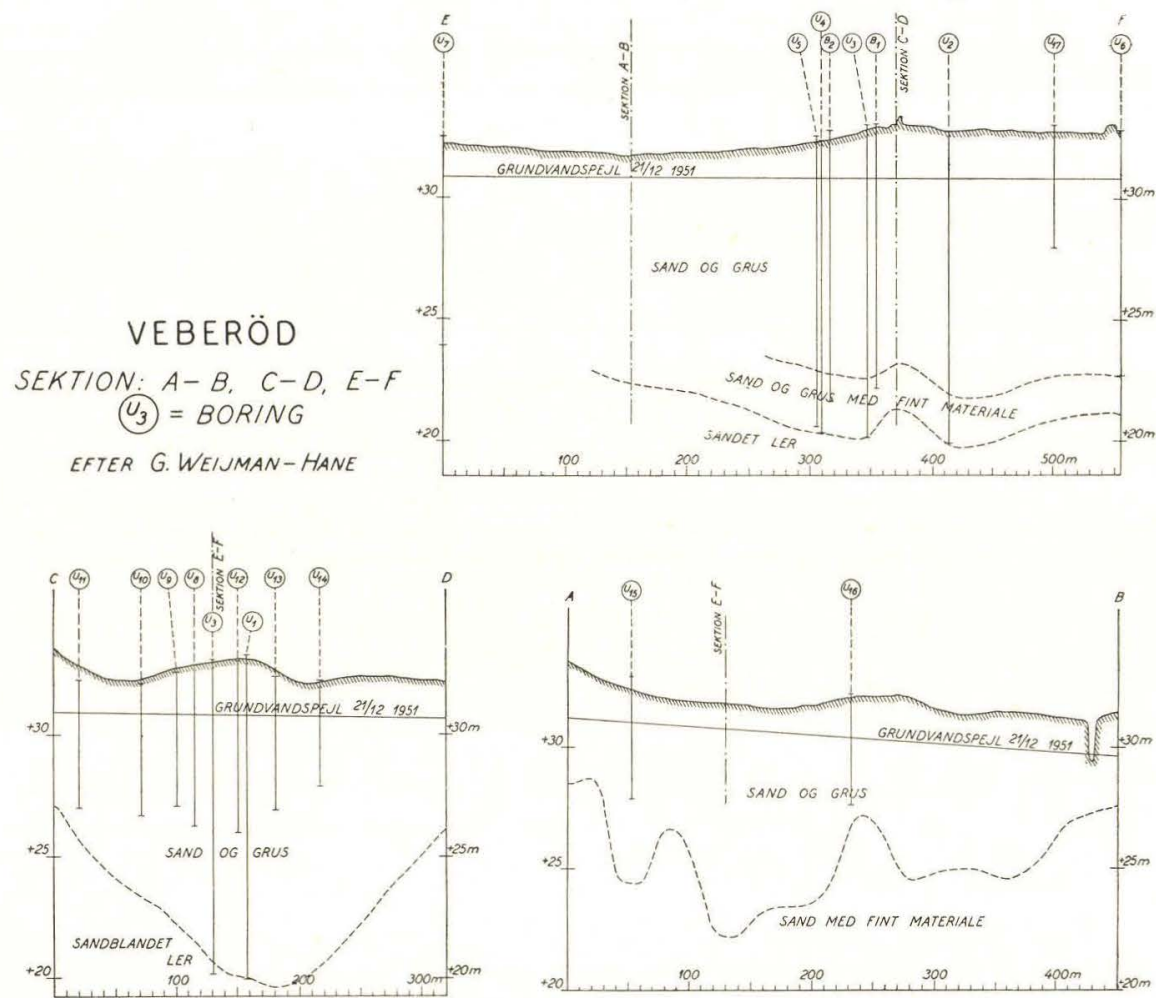

Fig. 28. Veberöd. Tværprofiler. Beliggenhed se fig. 26.

Cross sections (according to G. WeIJMan-HANE). Location see map fig. 26. Sand og grus: sand and gravel; sand med fint materiale: sand with silt; sandblandet ler \& sandet ler: sandy clay; grundvandspejl: groundwater table.

Ved kurvebilledet afgrænses øjensynlig to strøg med stor modstand, markeret ved positionerne 8 og 20 på 13.4 og ved positionerne 19 og 9 på 13.3.

Sammenlignes modstandsværdierne med de geologiske forhold, således som de er fremstillet skematisk på sektionerne $A-B, C-D$ og $E-F$ efter Weijman-Hane ses (fig. 28), at der er forholdsvis god korrelation mellem gruslagenes tykkelse og værdierne for $\varrho$. Det synes derfor berettiget at slutte, at områderne med stor modstand svarer til områder med vandførende sand og grus.

Kurveforløbet skulle antyde en sydøst-nordvestlig orientering af grusforekomsterne. Der er tilsyneladende god overensstemmelse mellem en sådan fortolkning og overfladelagenes fordeling på det geologiske kort, hvor der angives rullestengrus med en udbredelse, der nogenlunde synes at drkke modstandsmaximet.

Fortolkning af punktprofilerne. For de to punktprofiler $13.2 \mathrm{og}$ 13.5 (tavle II, fig. 7-8) kan generelt siges, at modstanden er stor over 
grundvandspejlet. De vandførende lag er kendetegnet ved relativ høj modstand. Faldet i modstandskurverne under boringernes slutdybde kunne være et tegn på større lerindhold, der er formodentlig tale om moræneaflejringer. De høje modstande, som antydes af kurvernes nederste del kunne måske skyldes tilstedeværelsen af prækvartære bjergarter.

Punktprofil 13.2. Veberöd. Ca. $140 \mathrm{~m}$ NNØ for Björkhaga og ca $10 \mathrm{~m}$ NNØ for slagboring ved pkt. $120 \mathrm{~m}$ Sektion. A-B. Målelinie ca. NNØ-SSV. Terræn $+32 \mathrm{~m} .8 / 5$ 1953. (Tavle II, fig. 7).

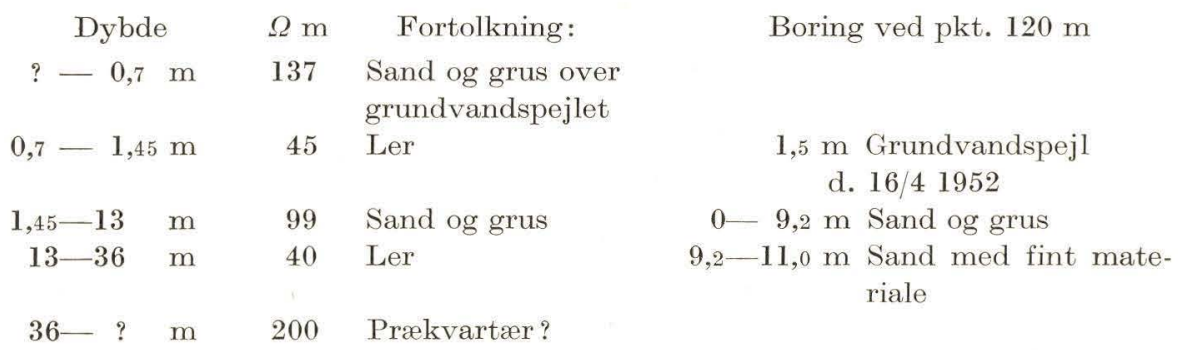

Punktprofil 13.5. Veberöd. Ca. $210 \mathrm{~m}$ ØNØ for Björkhaga ved boring U4. Skt. E-F. Terræn ca. +32,5 m. Målelinie ca. NNØ SSV. 9/5 1953. (Tavle II, fig. 8).

\begin{tabular}{|c|c|c|c|c|}
\hline Dybde & $\Omega \mathrm{m}$ & Fortolkning: & & Boring U.4 \\
\hline$?-2,4 \mathrm{~m}$ & 810 & $\begin{array}{l}\text { Sand og grus over } \\
\text { grundvandspejlet }\end{array}$ & & $\begin{array}{l}\text {,o } \mathrm{m} \text { Grundvandspejl } \\
\text { d. } 16 / 41952\end{array}$ \\
\hline $2,4-3,2 \mathrm{~m}$ & $89)$ & Sand og grus under & $0-9$ &, $5 \mathrm{~m}$ Grus \\
\hline $3,2-16 \mathrm{~m}$ & $87 \int$ & grundvandspejlet & $9,5-12$ & $\begin{array}{l}\text { m Grus med finkornet } \\
\text { materiale. }\end{array}$ \\
\hline $16-41$ & 43 & Ler & 12 & m Sandet lermoræne. \\
\hline $41-?$ & 306 & Prækvartær? & & \\
\hline
\end{tabular}

Resultaterne fra de to punktprofiler synes at bekræfte en vis grad af korrelation mellem modstandens variation og de ved boringerne fundne geo-hydrologiske forhold. Uoverensstemmelserne er ikke større, end at de kan tilskrives de kvartære lags uregelmæssige lejring.

7. Skive. I tiden 16-19/5 opmåltes et linieprofil nord for Skive (fig. 30, nr. 55.2) samt linieprofiler syd for byen med $a=50 \mathrm{~m}$ (fig. 29). Formålet med arbejdet var at kortlægge områder, udvalgt af stadsingeniør J. GeLlert i Skive med henblik på evt. boringer til Skive vandværk.

Den geologiske situation ved Skive er følgende. Undergrundens lag, der består af tertiære lerarter, når mange steder op i nærheden af terræn. I istiden er der på forskellige tidspunkter foregået dels en erosion af undergrundens lerlag, og dels en aflejring af istidsmateriale (SIGURD HANSEn 1948). Danskekalken findes først omkring $200 \mathrm{~m}$ dybde og indeholder saltvand. 


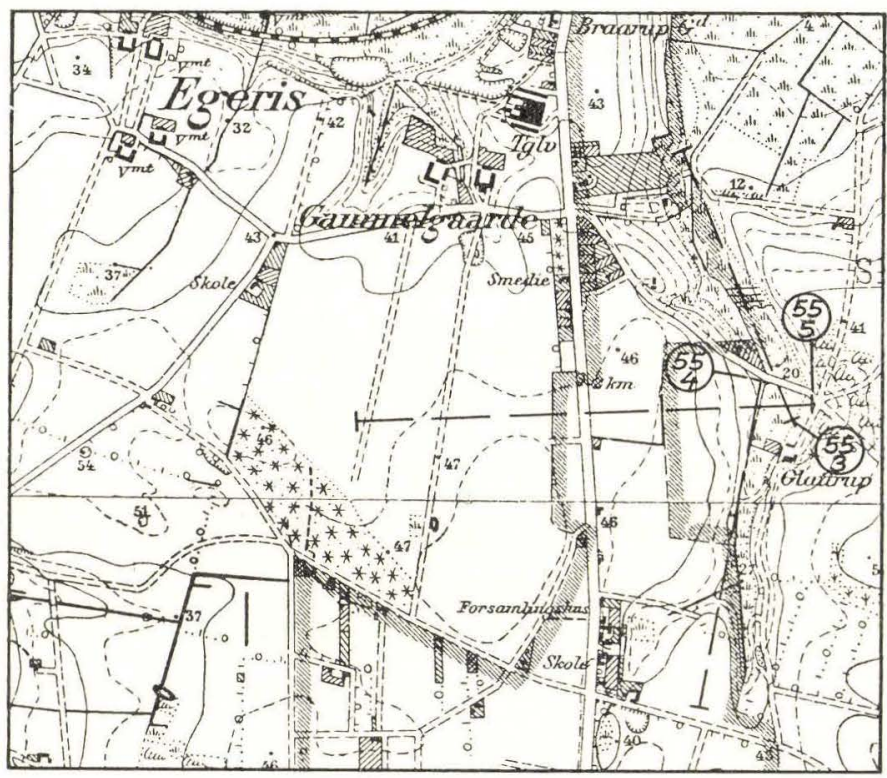

Fig. 29. Skive. Linieprofiler ved Glattrup S for Skive. Autoriseret reproduktion efter Geodætisk Institut M 1807 og M 1907. 1:20000.

Location of trenching lines. Scale $1: 20000$.

Som følge af de skitserede forhold kan kun vandførende sand- og gruslag i istidsaflejringerne komme i betragtning for vandindvindingen,

De geoelektriske undersøgelser vanskeliggjordes dels som følge af de tertiære lerlags nærhed ved overfladen og dels som følge af den tætte bebyggelse. Det var derfor ikke muligt at foretage en kortlægning i lighed med f. eks. Langstrup området. Liniesystemet kom til at bestå af løst sammenhængende linier, hvorved kurvedragningen $i$ høj grad vanskeliggjordes. Det fremstillede kortbillede kan derfor ikke gøre krav på nogen grad af nøjagtighed; kurverne må kun opfattes som en støtte til anskueliggørelsen af måleresultaternes variation (fig. 30).

Ved Skive gjorde et fænomen kendt under betegnelsen vagabonderende strømme sig særlig stærkt gældende. Vagabonderende strømme ytrer sig ved, at instrumentet giver udslag og altså registrerer en potentialforskel mellem potentialelektroderne, selv om der ikke frembringes strøm med generatoren. Vagabonderende strømme kan formodentlig opstå på forskellige måder. Ved Skive skyldtes de sikkert den tæutte bebyggelse og de i forbindelse hermed udstrakte elektriske ledningsnet, som på forskellig vis må formodes at skabe elektriske felter i den omgivende 


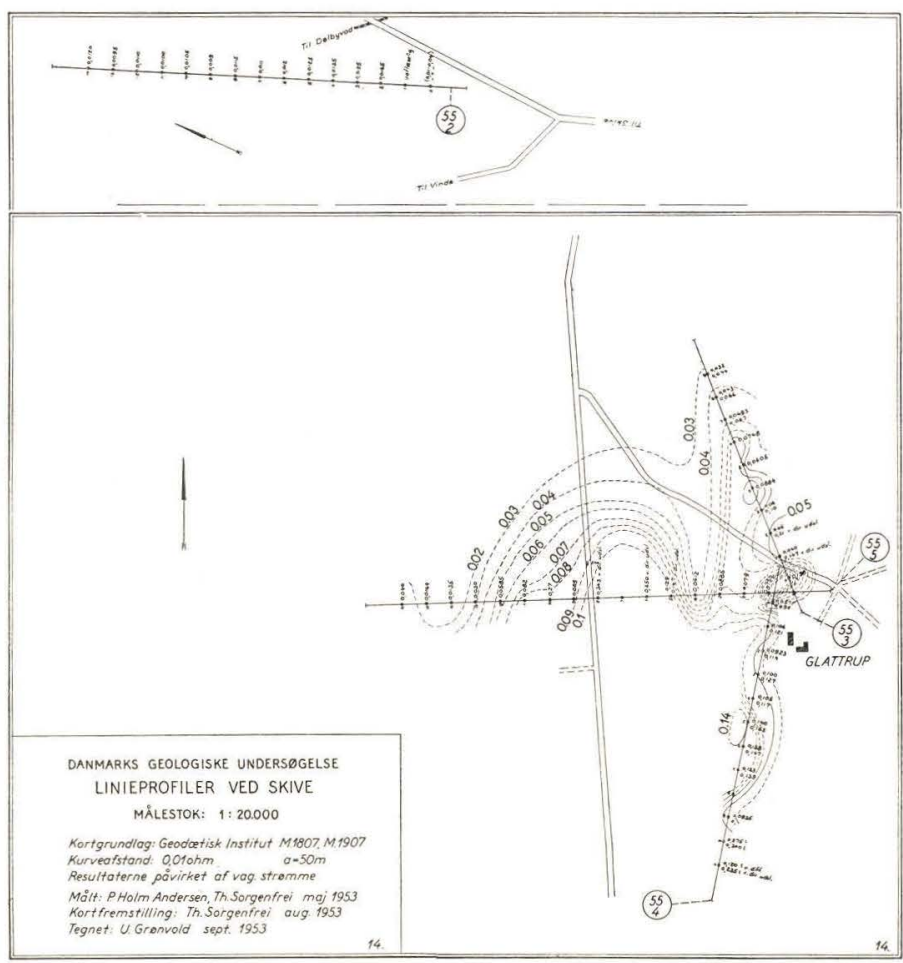

Fig. 30. Skive. Resistivity map. $a=50 \mathrm{~m}$. Measurements influenced by vagabondary currents. Scale 1:20000.

jordbund. Vagabonderende strømme i jorden kan medføre, at geoelektrisk opmåling i mangfoldige tilfælde helt umuliggøres.

Som følge af de vagabonderende strømme og på grund af den nævnte ringe terrænkontrol ved linieprofilerne står vi noget usikker overfor de opnåede resultater ved Skive.

I det nordlige område i dalen S for Frisenborg ved Vindebæk viste der sig meget små modstandsværdier. Man måtte derfor gå ud fra, at der ikke fandtes sandpartier af betydning i dalstrøget, hvor afdelingsingeniør L. M. ZACHARIASEN ud fra hydrologiske forstudier havde håbet på tilstedeværelsen af vandførende lag. Området blev opgivet efter fuldførelsen af den første linieopmåling.

Området ved Glattrup syd for Skive viste større variation med hensyn til modstanden. Der forekommer her formodentlig sand- og gruslag indenfor måledybden $50 \mathrm{~m}$. De meget hyppige vagabonderende strømme gør resultaterne meget usikre. I maximet S for Glattrup er siden udført en boring med følgende profil: 


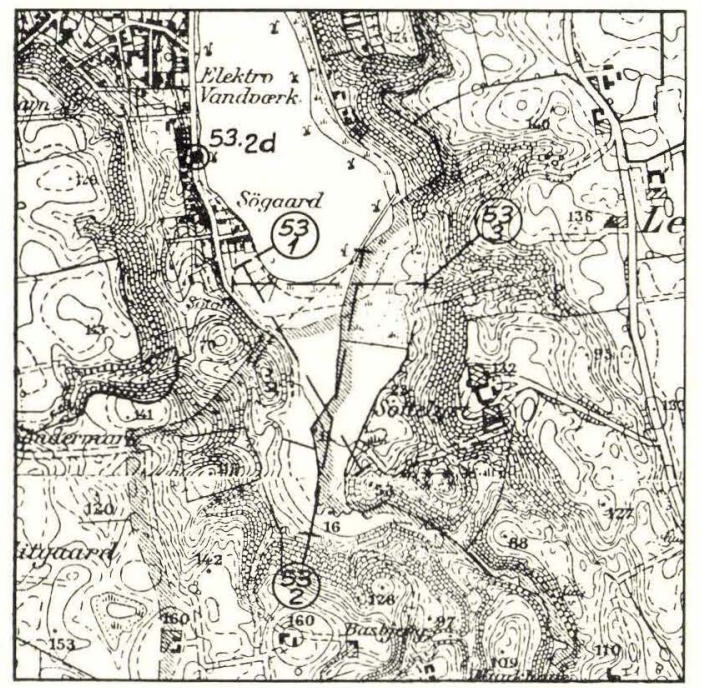

Fig. 31. Lemvig. Linieprofiler og beliggenhed af Lemvig vandværks boring $53.2_{\mathrm{d}}$. Autoriseret reproduktion efter Geodætisk Institut M 1802 og M 1902. 1:20 000.

Location of trenching lines and well no. 53.2 $\mathrm{d}$ of Lemvig waterworks. Scale 1:20 000.

Arkiv nr. 55.234. Glattrup. Skive vandværk. Boring 15/11-12/3 1954 i modstandsmaximum ea. $200 \mathrm{~m}$ SSV for Glattrup. Udført af Poul Christransen, Højslev.

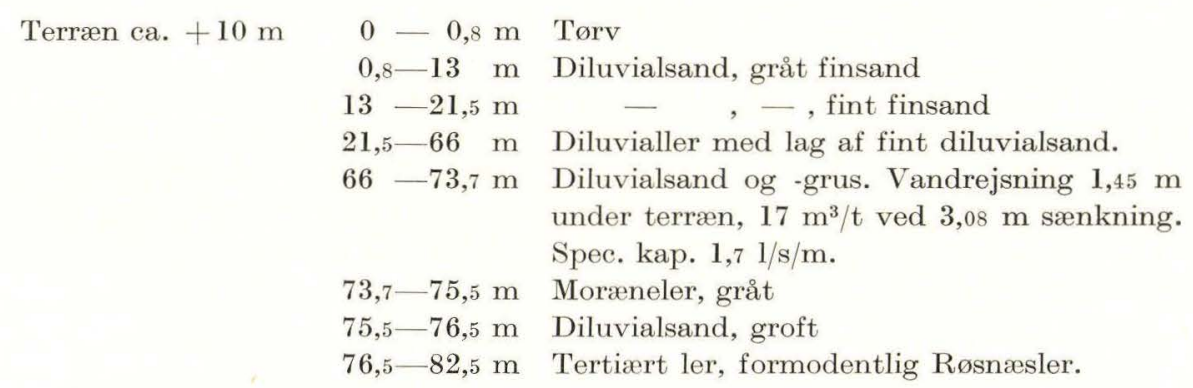

Det skal understreges, at det er meget usandsynligt, at det vandførende lag fra $66-73,7 \mathrm{~m}$ dybde har haft nogen målelig indflydelse på resultaterne fra linieopmålingen, idet det overliggende diluvialler uden tvivl virker som meget kraftig »skærmfaktor« p. gr. a. dets sikkert store ledningsevne. Det gunstige boreresultat set fra et vandindvindingsmæssigt synspunkt kan derfor i dette tilfælde ikke tages til indtægt for den geoelektriske fortolknings succes.

Punktprofil 55.1. Skive. Ca. $200 \mathrm{~m} \mathrm{NV}$ for $27 \mathrm{~km}$ stenen ved sydenden af Skive fjord, nordsiden af landevejen og ca. 1,1 $\mathrm{km}$ SØ for boring 


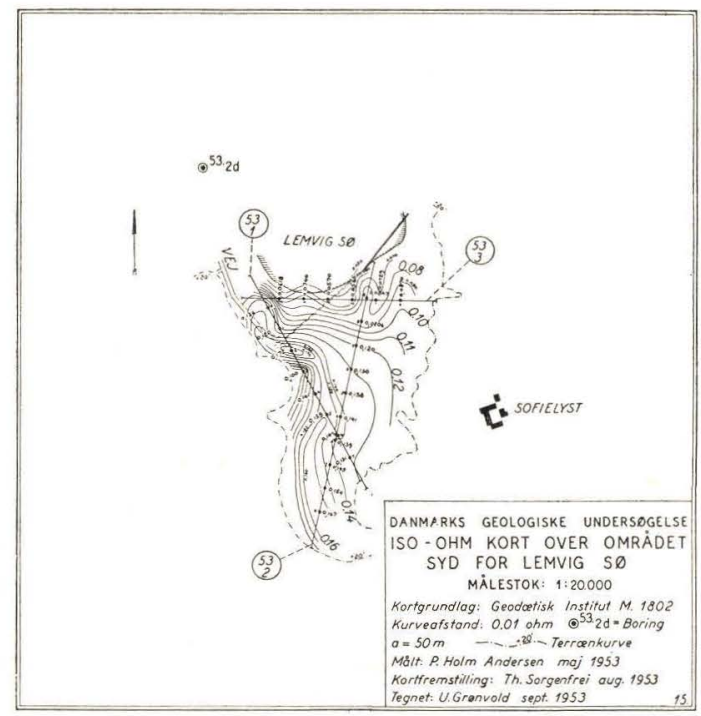

Fig. 32. Lemvig. Iso-ohm map, $a=50 \mathrm{~m}$, contour interval $0.01 \Omega$. Scale 1:20 000.

nr. 55.2 på Skive station. Måling med indtil $250 \mathrm{~m}$ elektrodeafstand parallelt med landevejen. 17/5 1953.

Denne måling udførtes for at prøve apparaturets effektivitet ved den store elektrodeafstand. Galvanometerudslaget viste sig ved dette forsøg at være så ringe ved $a=50 \mathrm{mog}$ derover, at aflæsningen var meget vanskelig. Måleresultaterne er afbildet grafisk på tavle III, fig. 9. En nummerisk analyse af kurven er umulig for den del, der svarer til $a>50 \mathrm{~m}$, idet $\varrho_{2} / \varrho_{1}$ ligger over $\infty$. Der bør iøvrigt ikke tillægges målingen for stor betydning, idet lokale forhold og evt. elektriske forstyrrelser ikke kan udelukkes som forstyrrende faktorer. Målingens betydning kan først vurderes, når der på andre egnede steder er fremskaffet flere måledata til lignende dybder. Som et resultat kan dog noteres, at det tertiære ler betegnet som Septarieler øjensynlig har meget ringe modstand (ca. $4 \Omega \mathrm{m}$ ).

8. Lemvig. Den $20 / 5$ opmåltes tre linieprofiler syd for Lemvig sø i tilknytning til en forespørgsel til D.G.U. fra stadsingeniør C. M. Iversen i Lemvig, angående nye boresteder til udvidelsen af Lemvig vandværk, der ligger i den sydlige udkant af byen (fig. 31).

De geologiske forhold ved Lemvig. Prækvartæret optræder formodentlig først under $100 \mathrm{~m}$ dybde i den største del af området. Byen ligger $i$ en dal, der er en fortsættelse af fjorddalen og har retningen NNV—SSØ. I den største del af dalen forekommer grundvandet sikkert under tryk, idet roligt vandspejl ved vandværkets boringer ca. $250 \mathrm{~m}$ N til V for Søgård står over terræn. Kilder langs dalsiderne tyder ligeledes herpå. Sandsynligheden taler meget stærkt for, at dalen er en tunnel- 
dal, der er opstået i sidste istid under indlandsisen, der havde en bevægelsesretning nord-syd i denne egn (Sigurd Hansen, 1948).

Den geoelektriske undersøgelse. Vandværket udnytter sandog gruslag i istidsdannelserne. De geologiske forhold betinger, at en udvidelse af indvindingen må være knyttet til sand- og gruslag i kvartæret udenfor de nuværende boringers indtagningsområde. Arbejdsprogrammet for modstandsmålingerne gik derfor ud på ved linieprofiler med $a=50 \mathrm{~m}$ at undersøge terrænet syd for Lemvig sø. I betragtning af de ensartede højdeforhold ved dalbunden, hvor terrænkoten kun varierer mellem ca. $+2,5 \mathrm{og}+4,5$, måtte man på forhånd gå ud fra, at eventuelle modstandsanomalier udelukkende skyldes jordlagene og vandet i porerne. Lagene over grundvandspejlet skønnedes ikke at have nogen større praktisk indflydelse på de målte modstandsværdier på grund af denne zones ringe tykkelse eller fuldstændige fraværelse.

Det elektriske anomalibillede på det udarbejdede iso-ohm kort viser karakteristiske træk (fig. 32). Et forholdsvis veldefineret, langstrakt modstandsmaximum strækker sig langs den vestlige dalside og ender mod syd ud for sidedalen, hvori Skjørbæk løber, og som tager sin begyndelse mod syd ved Kronhedes sandslette. Modstandsværdierne aftager nordpå fra maximet mod Lemvig sø og mod den østlige dalside.

Geologisk fortolkning. Maximet fortolkes som et udtryk for tilstedeværelsen af et relativt smalt strøg af sand- og gruslag, der er aflejret $\mathrm{i}$ en smeltevandstunnel under indlandsisen i istiden og siden dækket af moræneler. Det er rimeligt at formode, at denne aflejring aftegner en af tilførselsvejene for smeltevandet, der strømmede ud imod isranden ved Kronhede. Uden for isranden aflejredes sand og grus af smeltevandet i et mere forgrenet vandløbssystem, der her kunne brede sig til alle sider, hvorved Kronhedes udstrakte sand-og grusslette efterhånden blev dannet.

Undersøgelsen ved Lemvig kan formodentlig tages som et eksempel på en passende fordeling af målepunkter og linier i forhold til opgavens art og terrænets form. Det fremkomne kurvebillede må endvidere anses for at være et godt udtryk for jordlagenes variation i forhold til kortets målestok.

Hvis den geologiske fortolkning er rigtig, vil det være fordelagtigt at basere en fremtidig vandværksudvidelse på boringer i strøget med de maximale modstandsværdier, idet maximet ligger betydeligt udenfor de eksisterende boringers indtagningsområde.

Der er endnu ikke udført boringer i undersøgelsesområdet, idet man ved en boring $\mathbf{N}$ for Søgård, nærmere byen opnåede et tilfredsstillende resultat. Det skal tilføjes, at geoelektrisk måling var umulig her p. gr. a. bebyggelse.

9. Tåstrup. I 1932 påviste HiLmaR ØDuM, at der ved Tåstrup findes et begrænset område, hvor kalkundergrunden ligger under kote $-40 \mathrm{~m}$. 


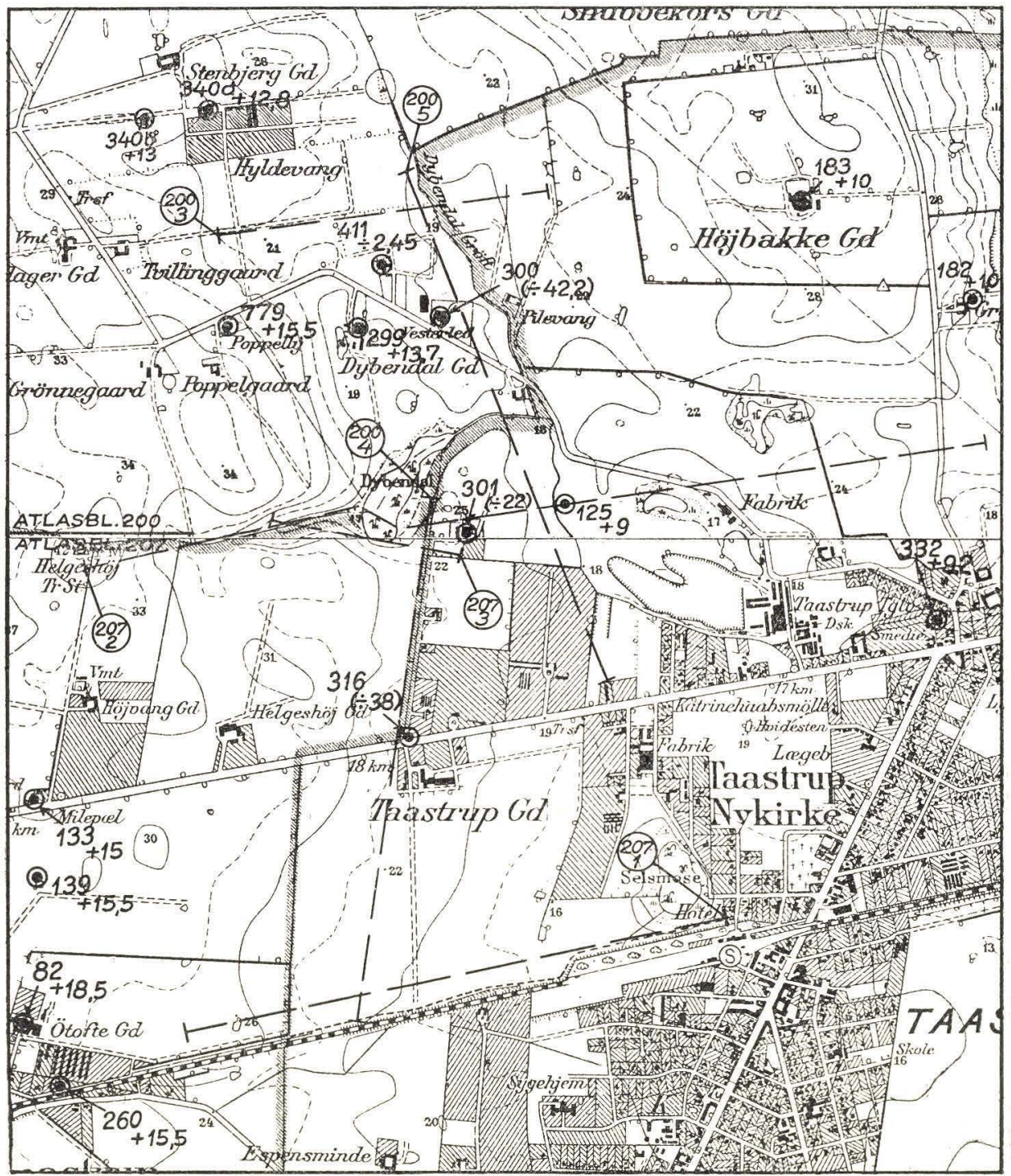

Fig. 33. Tåstrup. Linieprofiler (numre i cirkler) og boringer med arkivnummer og kalkkote eller slutkote kvartær (kotetal i parentes). Autoriseret reproduktion efter Geodætisk Institut M 3128 og M 3228. 1:20 000.

Location of trenching lines and wells. File number and elevation of top of Danian limestone (or final depth in Glacial Drift if in brackets) in metres shown at each well. Scale $1: 20000$.

I nærheden af de to boringer (blad 200, boring nr. $300 \mathrm{og} 301$ se fig. 33), som er trængt igennem tykke kvartærlag uden at nå kalken, findes adskillige boringer, hvori kalken er truffet ved dybder svarende til koteintervallet $+5-+20 \mathrm{~m}$. Kalken bestå i disse boringer af bryozokalk. Istidsdannelserne over kalken er fra 10 til $20 \mathrm{~m}$ tykke. 


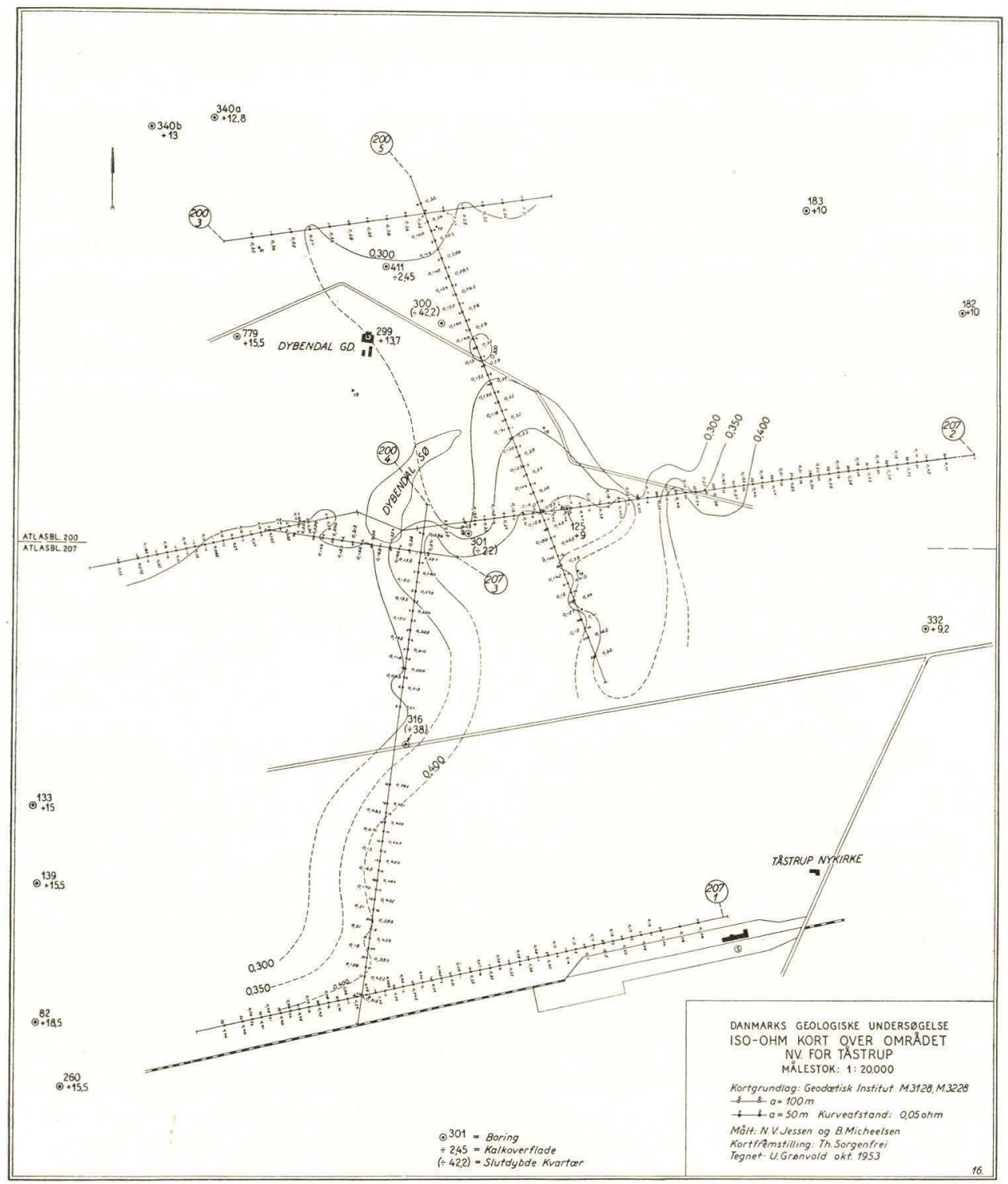

Fig. 34. Tåstrup. Iso-ohm map, $a=50 \mathrm{~m}$, contour interval $0.05 \Omega$. Scale $1: 20000$.

Siden 1932 er der til D.G.U.'s borearkiv indsendt oplysninger om nye boringer, som indkredser problemet om kalkdalens udstrækning yderligere. For at undersøge den geoelektriske metodes anvendelighed ved kortlægningen af undergrundens ujævnheder opstilledes et program for en geoelektrisk undersøgelse af det omtalte område ved Tåstrup. Opgaven gik ud på ved en kombineret linieopmåling at forsøge at kortlægge dalen samt at opmåle et par punktprofiler i nærheden på steder, hvor forholdene var tilstrækkelig klarlagt. 


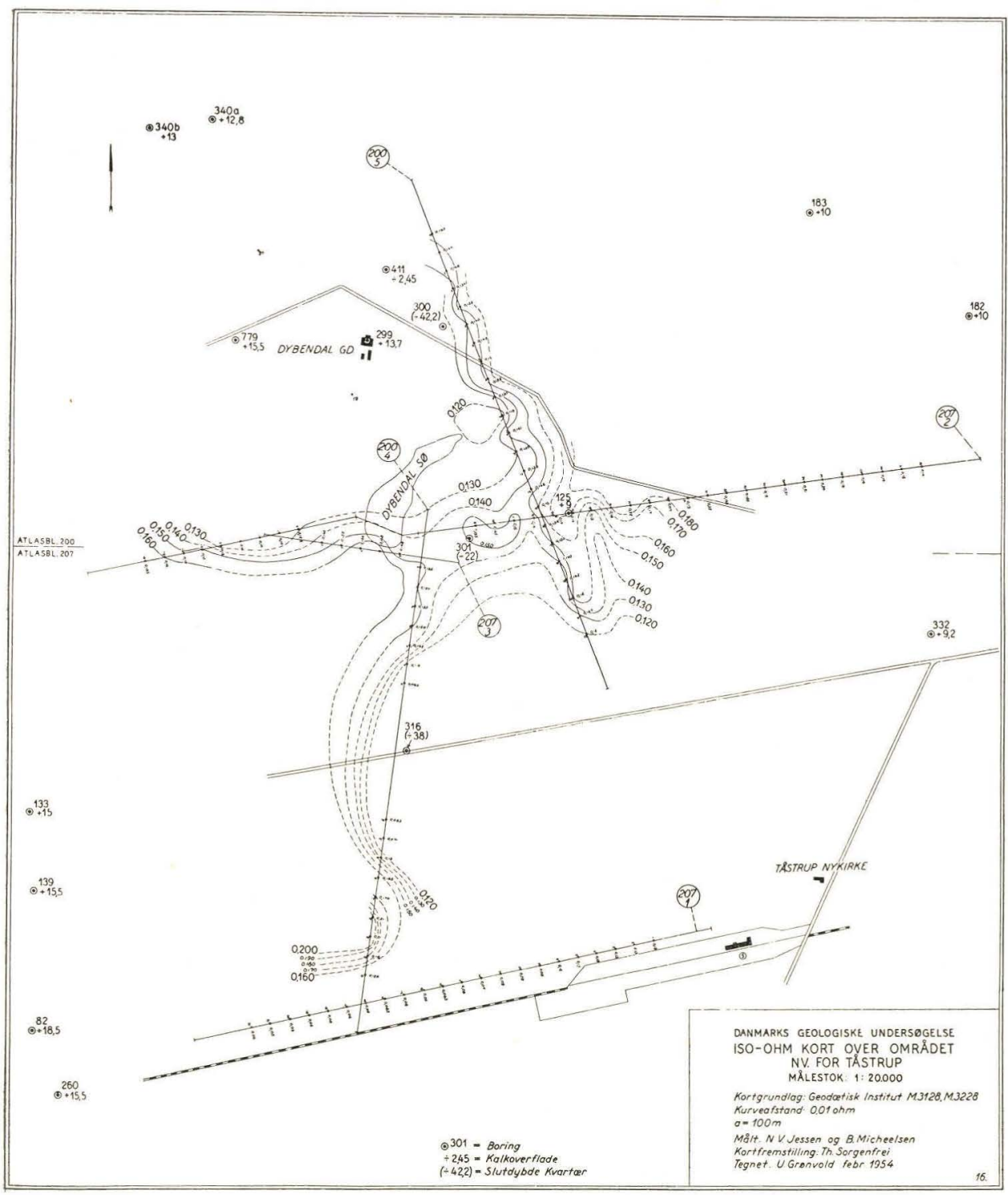

Fig. 35. Tåstrup. Iso-ohm map, $a=100 \mathrm{~m}$, contour interval $0.01 \Omega$. Scale 1:20 000.

Der blev lagt et system af linier ca. $\varnothing-V$ på tværs af dalens formodede retning, som blev forbundet ved et par nord-sydgående linier (fig. 33). Der foretoges målinger med $a=50 \mathrm{~m} \mathrm{og} a=100 \mathrm{~m}$. I Sengeløse mose udførtes to punktprofiler.

Selv om der er udført et meget omfattende arbejde, er undersøgelsesfeltet endnu ikke dækket med et tilstrækkelig tæt net af linier. De hidtil opnåede resultater viser imidlertid en del interessante træk, som fortjener omtale. 
På kortet over opmålingen med $a=50 \mathrm{~m}$ (fig. 34) antydes tilstedeværelsen af et modstandsmaximum over området med boringerne som endnu ikke har nået bryozokalken, mens der på kortet med $a=100 \mathrm{~m}$ (fig. 35) øjensynlig findes et minimum i den samme del af undersøgelsesfeltet (fig. $34-35$ ).

Den geologiske fortolkning af dette forhold kan muligvis blive følgende.

Ved linierne med $a=50 \mathrm{~m}$ vil det hovedsagelig være istidsdannelsernes modstande, som præger udtrykket for $R$. Fra boringerne ved vi, at der i dalen efter alt at dømme findes en del sand og grus, som dog ikke er særlig godt vandførende. Formodentlig er der for en væsentlig del tale om morænesand og -grus. I geoelektrisk henseende kan dette bevirke et lokalt modstandsmaximum over dalen.

Ved målingerne med $a=100 \mathrm{~m}$ vil den elektriske strøm i langt højere grad forløbe i kalken i de tilfælde, hvor målingerne er foretaget udenfor dalen end i dalen, som er udfyldt af kvartære jordlag. Kalkbjergarter viser normalt store modstandsværdier overfor den elektriske strøm, således som det f. eks. fremgår af undersøgelserne ved Herstedøster og på Stevns. De høje værdier ved Tåstrup tages derfor som et udtryk for kalkens indflydelse på $R$. I selve dalen vil de kvartære jordlag dominere modstandsværdierne. Selvom der som nævnt sikkert i nogen udstrækning er tale om sandede aflejringer, vil de ikke ubetydelige mængder lermateriale i lagene dog bevirke, at den elektriske modstand er lav i forhold til kalkbjergarterne, der flankerer dalen. Men dette betyder, at der med den større elektrodeafstand netop må aftegne sig et lokalt modstandsminimum over dalen.

Som nævnt betragtes Tåstrupundersøgelsen ikke som afsluttet. Det er hensigten at lægge yderligere profillinier igennem terrænet for at få klarlagt, om den her givne fortolkning kan opretholdes. De målte punktprofiler viste meget ekstreme modstandsforhold og skal ikke kommenteres.

10. Rislev. Geologiske forhold. I 1923 beskrev Hee Andersen og Hilmar Ødum en forekomst af saltvandsplanter midt inde i land, i Rislev mose nord for Næstved. Ved senere boringer er de geologiske forhold oplyst (Johs. Andersen og Hilmar Ødum, 1930), og man har påvist tilstedeværelsen af salt grundvand. Kvartæret består efter ØDUMS undersøgelse af moræne med indlejrede lag af smeltevandssand og -grus, og dybgrundens lag består af bryozokalk, der allerede findes ved ca. $8 \mathrm{~m}$ dybde. Vandet fra kalken i den centrale del af mosen viste sig at indeholde $0,625 \% \mathrm{Cl}^{-}$, svarende til $1,030 \% \mathrm{NaCl}$.

Hee Andersen og ØDum har på et kort vist udbredelsen af saltbundsplanterne i 1923.

Den geoelektriske undersøgelse. Det blev besluttet at kortlægge Rislev mose geoelektrisk for at forsøge at få et overblik over saltvandets 
eventuelle indflydelse på modstandsværdierne. Hensigten var både at gennemføre liniemålingerne med $a=50 \mathrm{mog} a=25 \mathrm{~m}$ samt at udføre en punktopmåling på et passende sted. Undersøgelsen fandt sted fra 18—27/8 1953.

Der blev lagt en nord-sydgående hovedlinie samt to tværlinier gennem terrænet (fig. 36). Det viste sig dog, at $50 \mathrm{~m}$ målingerne ikke kunne gennemføres, idet galvanometeret ikke gav aflæselige udslag med denne elektrodeafstand, hvilket øjensynlig skyldes de saltvandsførende jordlags store ledningsevne og de overliggende lags ringe tykkelse. Det lykkedes at opnå forholdsvis gode resultater ved $a=25 \mathrm{~m}$.

Det udarbejdede iso-ohm kort er meget enkelt. Det viser en smuk korrelation mellem iso-ohm kurverne og udbredelsesgræensen for saltbundsfloraen. De lave modstandsværdier i centret af undersøgelsesfeltet tilskrives det optrængende saltvand (fig. 37 ).

Anomaliens langstrakte form kunne måske føre til den antagelse, at der er tale om en saltvandsinfiltration fra den dybere undergrund gennem en N-S gående spaltezone. En sådan hypothese kan heller ikke afvises. Anomaliens kurver viser imidlertid en iøjnefaldende konformitet med moseområdet og terrænkurverne. Sammenholdes dette med terrænets lave beliggenhed og de gode afstrømningsmuligheder for grundvandet i kalken til vandløb og dæmningsgrøfter gennem eventuelle sandlag, må saltvandets optrængen snarere ses som en følge af de hydrostatiske forhold. Grundvandets afledning vest for Stenskovområdet fremkalder sandsynligvis et hydrostatisk undertryk i Slagmosen, hvorved de dybere grundvandshorisonter registrerer et lokalt overtryk, der må resultere i en opadgående vandbevægelse. Det er sandsynligt, at saltvandets optræden må ses ud fra et sådant synspunkt, hvilket naturligvis ikke udelukker, at også en spaltezone kan indgå i billedet. Det må dog fremhæves, at den elektriske kortlægning hverken leverer noget bevis for en spaltezones tilstedeværelse eller berettiger til nogen konklusion m. h. t. en eventuel spaltezones orientering.

Der udførtes et dobbelt punktprofil ca. $60 \mathrm{~m}$ ØSØ for den i sin tid udførte boring $216.15 \mathrm{~b}$ (=) boring $B$, JoHs. Andersen og Hilmar Ødum 1930 , p. 63), hvis boreprofil også er gengivet på diagrammet med modstandskurverne (tavle III fig. 10).

Nedenfor anføres de udregnede dybdeintervaller og tilhørende specifike modstande.

Punktprofil 216.5. Rislev Mose. Ca. $600 \mathrm{~m}$ ØNØ for Rislev kirke. Terræn ca. $+6 \mathrm{~m} .27 / 8$ 1953. (Tavle III, fig. 10).

A. Nord-syd linien

\begin{tabular}{|c|c|c|}
\hline Dybde & $(\Omega \mathrm{m})$ & Fortolkning \\
\hline $0-0,14 \mathrm{~m}$ & 59 & \\
\hline $0,14-0,3 \mathrm{~m}$ & 39 & Sand, tørv? \\
\hline $0,3-0,36 \mathrm{~m}$ & 46 & \\
\hline
\end{tabular}




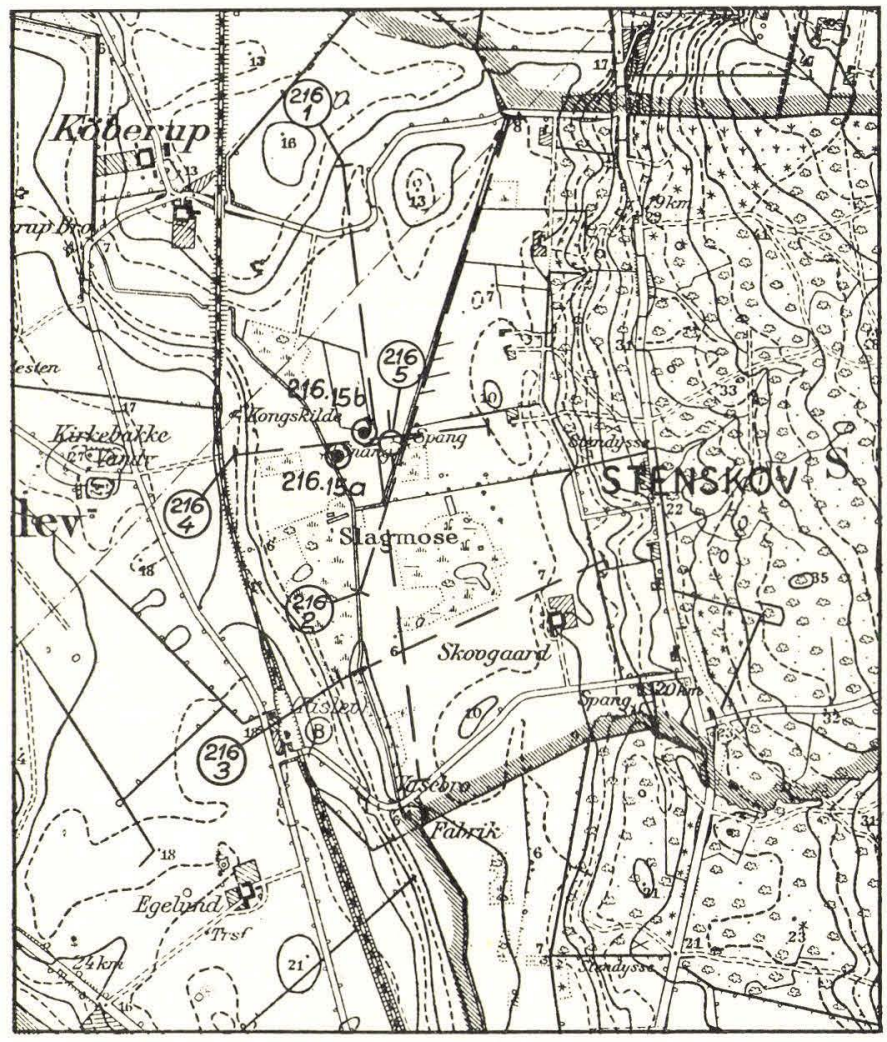

Fig. 36. Rislev. Linieprofiler, punktprofil (numre i cirkler) og boringer. (216.15a-b). Autoriseret reproduktion efter Geodætisk Institut M 3725. 1:20000.

Location of trenching lines, electrical drilling (encircled file numbers) and wells $\left(216.15_{\mathrm{a}} \mathrm{b}\right)$. Scale 1:20000.

$\begin{array}{rlrl}0,36-3,4 & \mathrm{~m} & 15,2 & \text { Ler } \\ 3,4-11,0 & \mathrm{~m} & 48,5 & \text { Sand og ler } \\ 11,0-\quad ? & \mathrm{~m} & 6,6 & \text { Bryozokalk m. saltvand }\end{array}$

B. Øst_-vest linien

\begin{tabular}{|c|c|c|}
\hline Dybde & $(\Omega \mathrm{m})$ & Fortolkning: \\
\hline $0-0,2 \mathrm{~m}$ & 48 & \multirow{2}{*}{ Sand, tørv? } \\
\hline $0,2-0,3 \mathrm{~m}$ & 32 & \\
\hline $0,3-1,8 \mathrm{~m}$ & 13,5 & \multirow{2}{*}{ Ler } \\
\hline $1,8-5,4 \mathrm{~m}$ & $23,2\}$ & \\
\hline $5,4-8,2 \mathrm{~m}$ & 60,0 & Sand og ler \\
\hline $8,2-26,0$ & 21,3 & Bryozokalk med noget saltvand \\
\hline $6,0-? \mathrm{~m}$ & 5,5 & _ $\quad$ med saltvand \\
\hline
\end{tabular}

Modstandskurverne synes i store træk at være korrelerbare med boreprofilet. Saltvandets tilstedeværelse bevirker dog tydeligvis en kraftig 


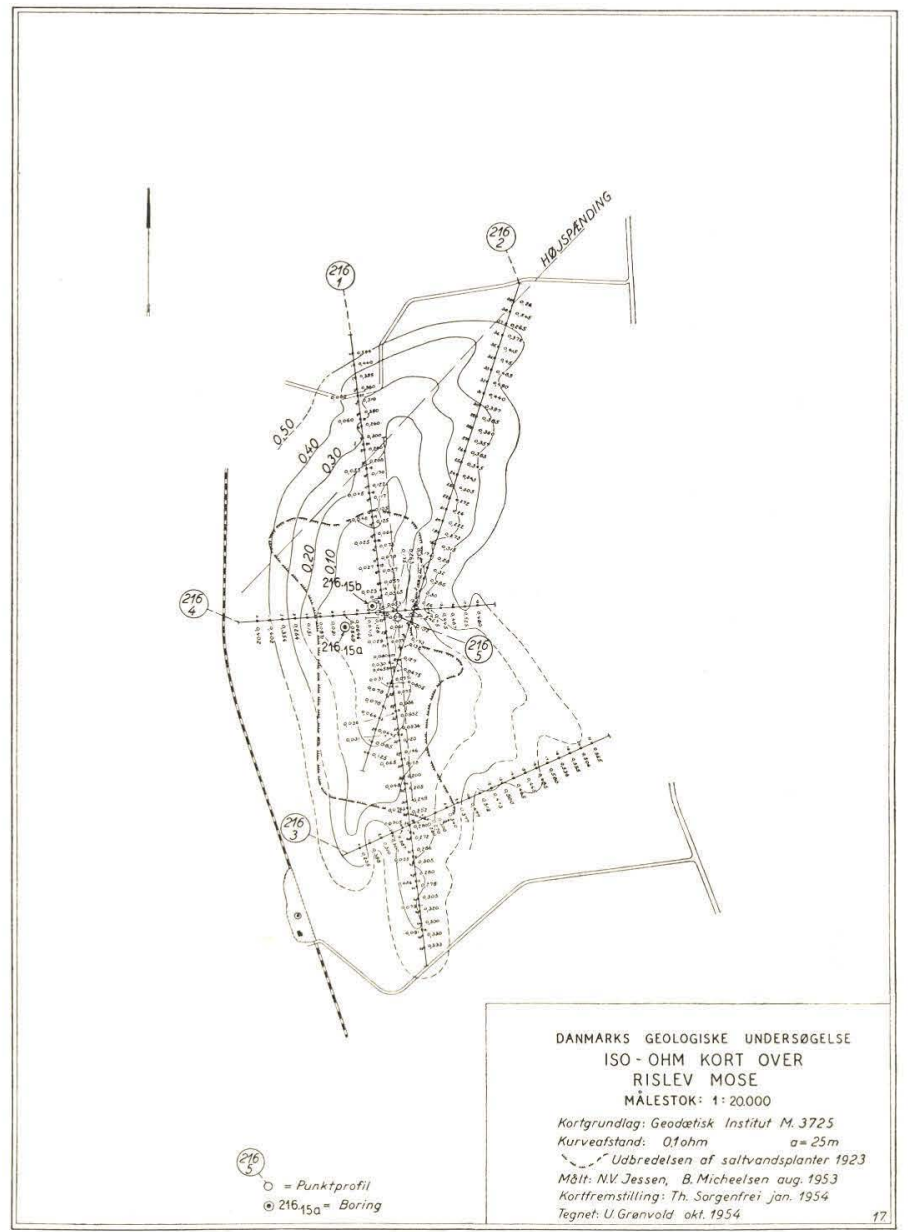

Fig. 37. Rislev. Iso-ohm map, $a=25 \mathrm{~m}$, contour interval $0.1 \Omega$. Scale $1: 20000$.

nedsættelse af modstandsværdierne for bryozokalken, når man sammenligner med målingerne på Stevns. På grund af saltvandets tilstedeværelse i terrænet må jordartstolkningerne betragtes med noget forbehold. Dybdebestemmelsen for kalkoverfladen på $\varnothing-\mathrm{V}$ linien passer nøjagtigt med boreprofilet for boring 216.15.b, som det fremgår af punktprofildiagrammet. Dette harmonerer også godt med forholdet, at kalkoverfladen ligeledes er truffet i denne dybde i boring 216.15.a, der ligger ca. $60 \mathrm{~m}$ SØ for boring 216.15.b.

Efter resultaterne fra $\mathrm{N}-\mathrm{S}$ linien skulle man antage noget mindre ensartethed i kalkoverfladens beliggenhed i denne retning samt en kraftigere inficering med saltvand. Dette sidste er jo iøvrigt allerede sandsynliggjort ved linieopmålingen, idet saltvandet efter fortolkningen af denne undersøgelse skulle trænge op i et aflangt, $\mathrm{N}-\mathrm{S}$ orienteret område. 


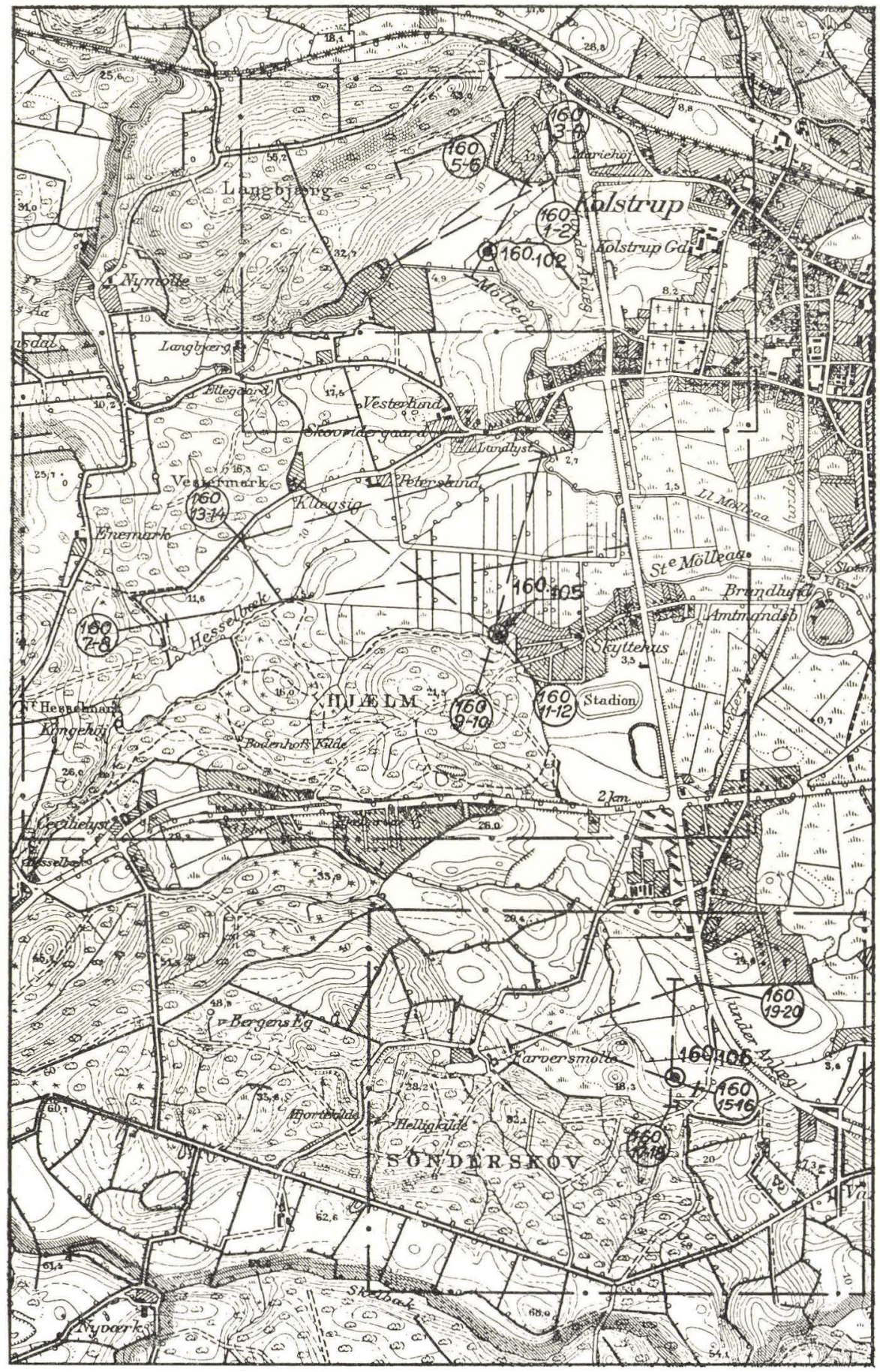

Fig. 38. Åbenrå. Undersøgelsesfelterne ved Kolstrup, Hjælm og Farversmølle med linieprofiler og boringer (henholdsvis indkredsede og ikke indkredsede arkivnumre). Autoriseret reproduktion efter Geodætisk Institut M 4109. 1:20 000.

Location of trenching lines (encircled file numbers) and wells. Scale 1:20 000. 
11. Åbenrå. I forbindelse med vandværkets boreprogram for tre undersøgelsesboringer vest og syd for byen gennemførtes linieopmålinger ved Kolstrup, Hjælm og Farversmølle (fig. 38).

De geologiske forhold ved Ảbenrå. Åbenrå fjord er sandsynligvis dannet $\mathrm{i}$ sidste istid af en gletschertunge, der bevægede sig fra øst mod vest (A. JESSEN, 1945). Den nåede formodentlig ud til terrænet vest for Årslev. I fjordområdet optræder meget hyppigt store flager af fedt, interglacialt ler i istidsdannelserne, og moræneaflejringerne er almindeligvis præget af at være stærkt blandet med interglacialt ler. Istidserosionen er gået ned til ca. $120 \mathrm{~m}$ dybde. Underlaget består øjensynlig af glimmerler, hvori der hidtil ikke er fundet og heller ikke kan ventes at forekomme vandførende lag af interesse for vandindvindingen. Vandførende lag må derfor søges i istidsdannelserne. Sand- og gruslag formodes kun at være sparsomt til stede.

Vandværket placerede først to boringer med D.G.U.'s assistance på almindelig geo-hydrologisk indikation, een ved Kolstrup, og een ved Hjælm som vist på kortet fig. 38. De blev ført ned til henholdsvis 95,5 m (ark. nr. 160.102) og $92 \mathrm{~m}$ (ark. nr. 160.105) uden at træffe vandførende lag, når der ses bort fra enkelte underordnede lag af størrelsesordenen $1-2 \mathrm{~m}$.

Ved de påfølgende geoelektriske undersøgelser, der gennemførtes som linieopmålinger med $a=25 \mathrm{~m}$ og $a=50 \mathrm{~m}$ konstateredes, at de to boringer var udført på steder med meget lave modstandsværdier. (Sekortene fig. 39-40).

Boreprofilet ser således ud:

Arkiv nr. 160.106. Åbenrå vandværk, boring nr. 3, Farversmølle. Udført af K. Fr. Sснмidt, Christiansfeld jan.-febr. 1954.

$\begin{array}{ccl}\text { Terræn ca. }+8 \mathrm{~m} \quad 0,25 \mathrm{~m} & \text { Tørv } \\ 0,25-0,55 \mathrm{~m} & \text { Moræneler } \\ 0,55-1,2 \mathrm{~m} & \text { Smeltevandssand, leret } \\ 1,2-2,7 \mathrm{~m} & \text { Sand, mørkt, leret } \\ 2,7-10,0 \mathrm{~m} & \text { Smeltevandssand og -grus, stenet } \\ 10,0-11,3 \mathrm{~m} & \text { Ler og sten (moræne?) } \\ 11,3-13,8 \mathrm{~m} & \text { Smeltevandssand og -grus (vandførende) } \\ 13,8-15,8 \mathrm{~m} & \text { Smeltevandssand, gråt, fint, leret } \\ 15,8-29,0 \mathrm{~m} & \text { Smeltevandssand, finsandet } \\ 29,0-31,0 \mathrm{~m} & \text { Smeltevandssand og -grus, vandførende } \\ 31,0-31,5 \mathrm{~m} & \text { Smeltevandsler } \\ 31,5-32,5 \mathrm{~m} & \text { Smeltevandssand, fint } \\ 32,5-35,5 \mathrm{~m} & \text { Smeltevandsgrus og -sand, stenet, vandrejs- } \\ & & \text { ning ca. } 1 \text { m under terræn } \\ 35,5-37,85 \mathrm{~m} & \text { Smeltevandssand, fint, leret } \\ 37,85-52,0 \mathrm{~m} & \text { Ler med sandlag, øjensynlig delvis smelte- } \\ & & \text { vandsler og -sand } \\ 52,0-59,0 \mathrm{~m} & \text { Lerblandet grus og sand, moræne? } \\ 59,0-60,0 \mathrm{~m} & \text { Smeltevandssand, stenet, vandførende } \\ 60,0-65,0 \mathrm{~m} & \text { Leret grus og sand, moræne? } \\ 65,0-66,0 \mathrm{~m} & \text { Smeltevandssand og -grus, vandførende } \\ 66,0-78,0 \mathrm{~m} & \text { Leret grus og sand, øjensynlig smeltevands- } \\ & & \text { aflejringer blandet med moræne }\end{array}$




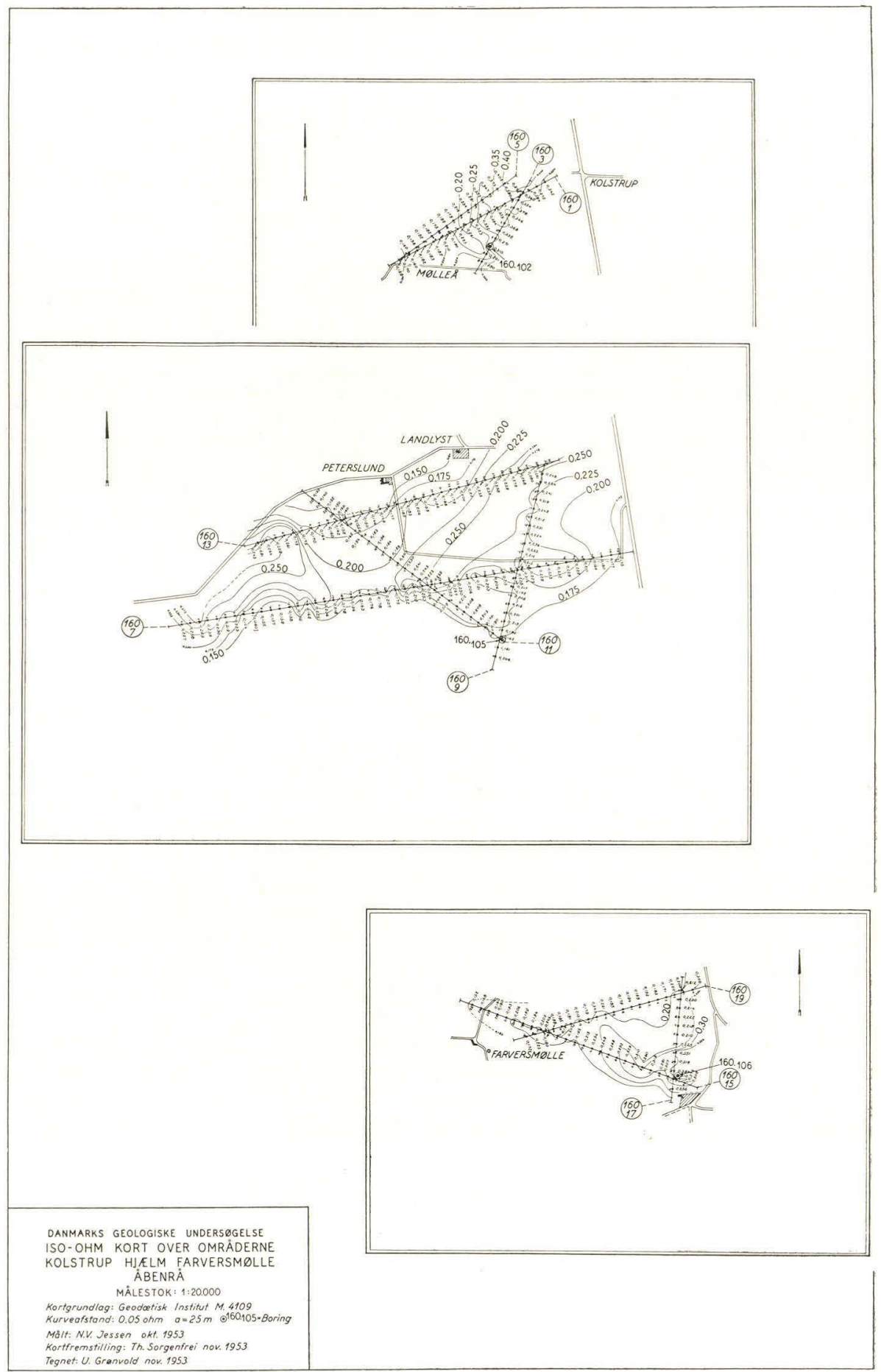

Fig. 39. Åbenrå. Iso-ohm map, $a=25 \mathrm{~m}$, contour interval $0.05 \Omega$. Scale $1: 20000$. 
Danmarks Geologiske Undersøgelse. III. Række. Nr. 32.

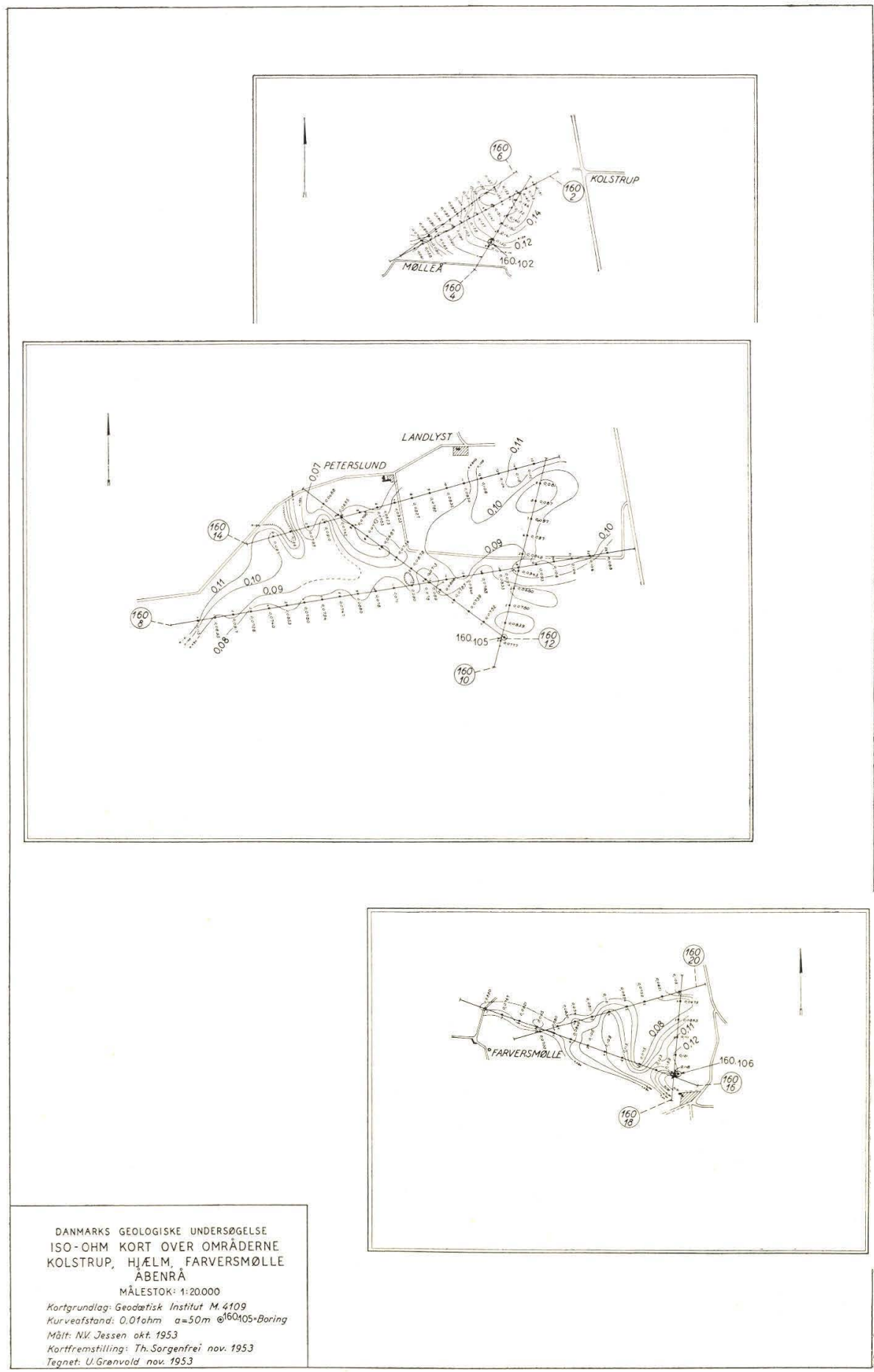

Fig. 40. Åbenrå. Iso-ohm map, $a=50 \mathrm{~m}$, contour interval 0.01 $\Omega$. Seale 1:20000. 
Boring nr. 3 udførtes ved Farversmølle efter den geoelektriske undersøgelse. Den anbragtes ca. $500 \mathrm{~m} \mathrm{~V}$ for Farversmølle, hvor der både ved $25 \mathrm{og} 50 \mathrm{~m}$ trenching har vist sig et lokalt maximum for modstandsværdierne, som det fremgår af kortene fig. 39-40.

Der er ikke udført nogen prøvepumpning i de vandførende lag.

Med påvisningen af de ikke helt ubetydelige sand- og gruslag ved Farversmølle indenfor det lokale modstandsmaximum er det således lykkedes at demonstrere en god korrelation mellem de geoelektriske modstandsmålinger og de udførte boringer i alle tre undersøgelsesfelter ved Åbenrå.

12. Ollerup. I de senere år har Svendborg vandværk udført en række undersøgelsesboringer i området mellem Svendborg og Ollerup. Da man i dalen fra Hvidkilde over Nielstrup til Ollerup havde udført en del boringer, som ikke traf på særlig gode vandførende lag, anmodede vandværksbestyrer R. Kromann Madsen D.G.U. om at gennemføre en geoelektrisk undersøgelse i området.

For at give et fyldigere overblik over de geologiske forhold til belysning af de geoelektriske resultater anføres nedenfor i forenklet form boreprofilerne for Svendborg vandværks boringer P6-P9 og P13-P14, som er udført i undersøgelsesterrænet, inden den geoelektriske undersøgelses afslutning. Boringerne er afmærket på målebordsblad-udsnittet fig. 41 .

Arkiv nr. 164.122. Hvidkilde. Svendborg vandværks prøveboring P.6, $\mathrm{N}$ for Hvidkilde. Udført af V. STOFFREGEN, Silkeborg, okt. 1950.

$\begin{array}{rrl}\text { Terræn }+32,7 \mathrm{~m} & 0-0,3 \mathrm{~m} & \text { Muld } \\ 0,3-21,8 \mathrm{~m} & \text { Moræneler, delvis forvitret og sandet } \\ 21,8-33,3 \mathrm{~m} & \text { Smeltevandssand og -grus. Vandrejsning 2,8 } \mathrm{m} \\ & \text { under terræn. } 62 \mathrm{~m}^{3} / \mathrm{t} \text { ved 2,25 } \mathrm{m} \text { sænkning } \\ & \text { (spec. kap. 7,6 } 1 / \mathrm{s} / \mathrm{m} \text { ) } \\ 33,3-33,5 \mathrm{~m} & \text { Finsand, leret (smeltevandssand) }\end{array}$

Arkiv nr. 164.124. Hvidkilde. Svendborg vandværks prøveboring P.7, N for Hvidkilde. Udført af V. STOFFREgen, Silkeborg, marts 1951.

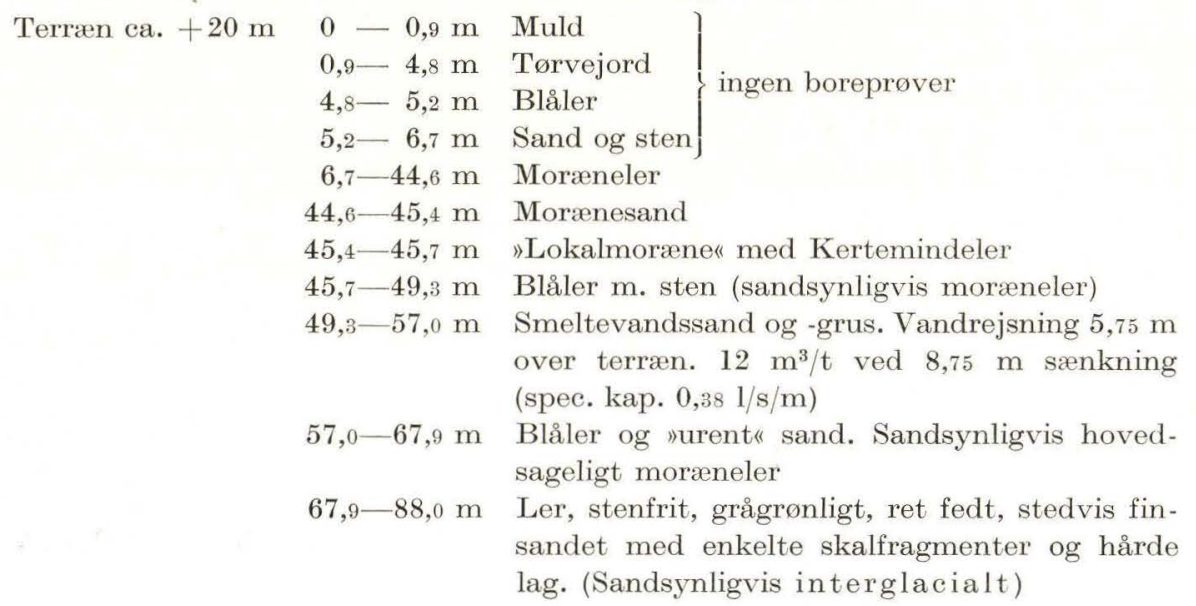


Arkiv nr. 164.125. Nielstrup. Svendborg vandværks prøveboring P.8, S for Nielstrup. Udført af V. STOFFregen, Silkeborg, juli 1951.

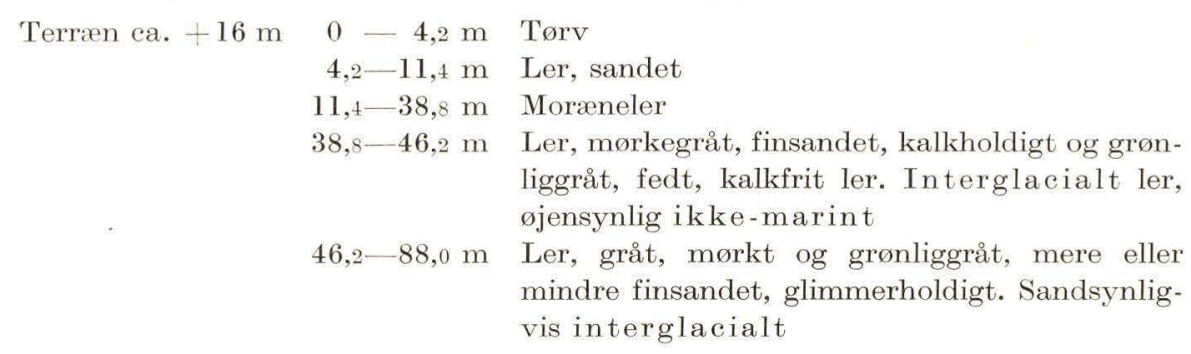

Arkiv nr. 164.130. Ollerup. Svendborg vandværks prøveboring P.9, N for gymnastikhøjskolen i Åmosen. Udført af V. Stoffregen, dec. 1951-jan. 1952.

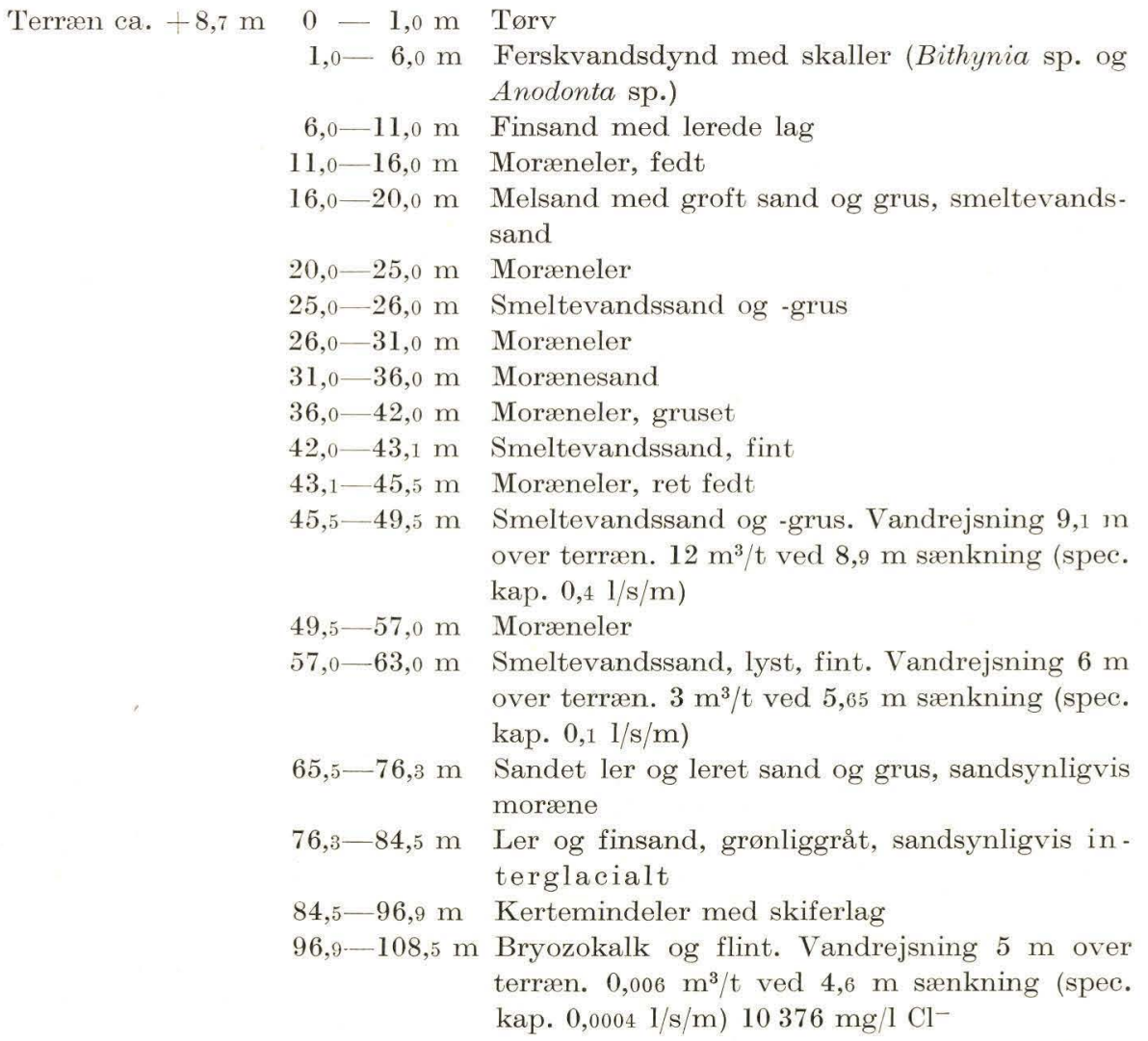

Arkiv nr. 164.131. Ollerup. Svendborg vandværks prøveboring P.14, S for Ollerup ved Ollerup sø. Udført af V. STOFFREGEN, okt.-nov. 1953.

$$
\begin{array}{lll}
\text { Terræn }+12,9 \mathrm{~m} \quad & 0-0,2 \mathrm{~m} & \text { Muld } \\
& 0,2-0,6 \mathrm{~m} \text { Sand, leret } \\
& 0,6-1,1 \mathrm{~m} \text { Tørv, sneglegytje (?) }
\end{array}
$$




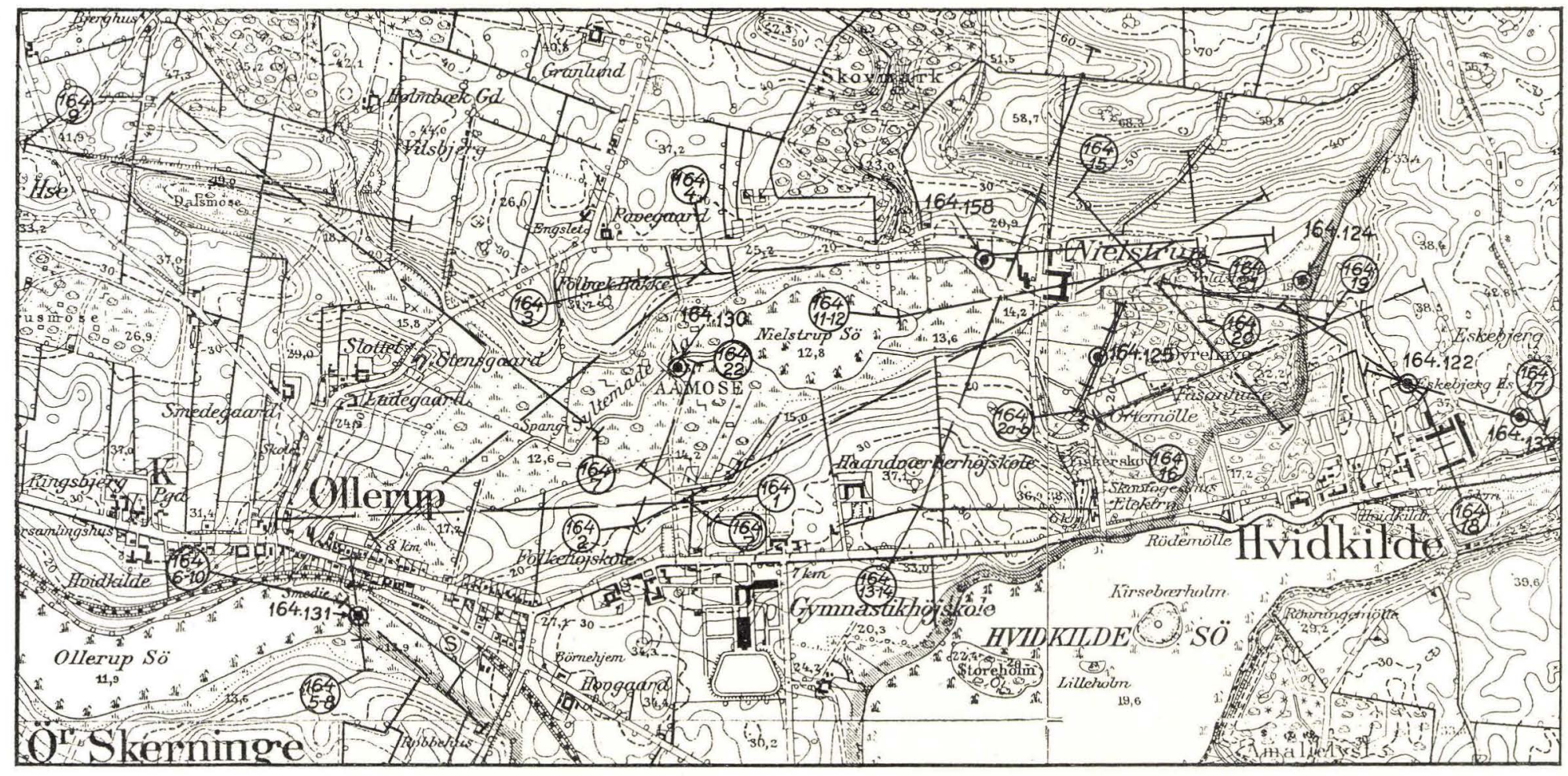

Fig. 41. Ollerup. Linieprofiler, punktprofiler (numre i cirkler) og boringer (delvist udfyldte cirkler). Autoriseret reproduktion efter Geodætisk Institut M 4016, M 4116, M 4017 og M 4117. 1:20 000.

Location of trenching lines, electrical drillings (encircled file numbers) and wells (partly filled circles). Scale $1: 20000$. 


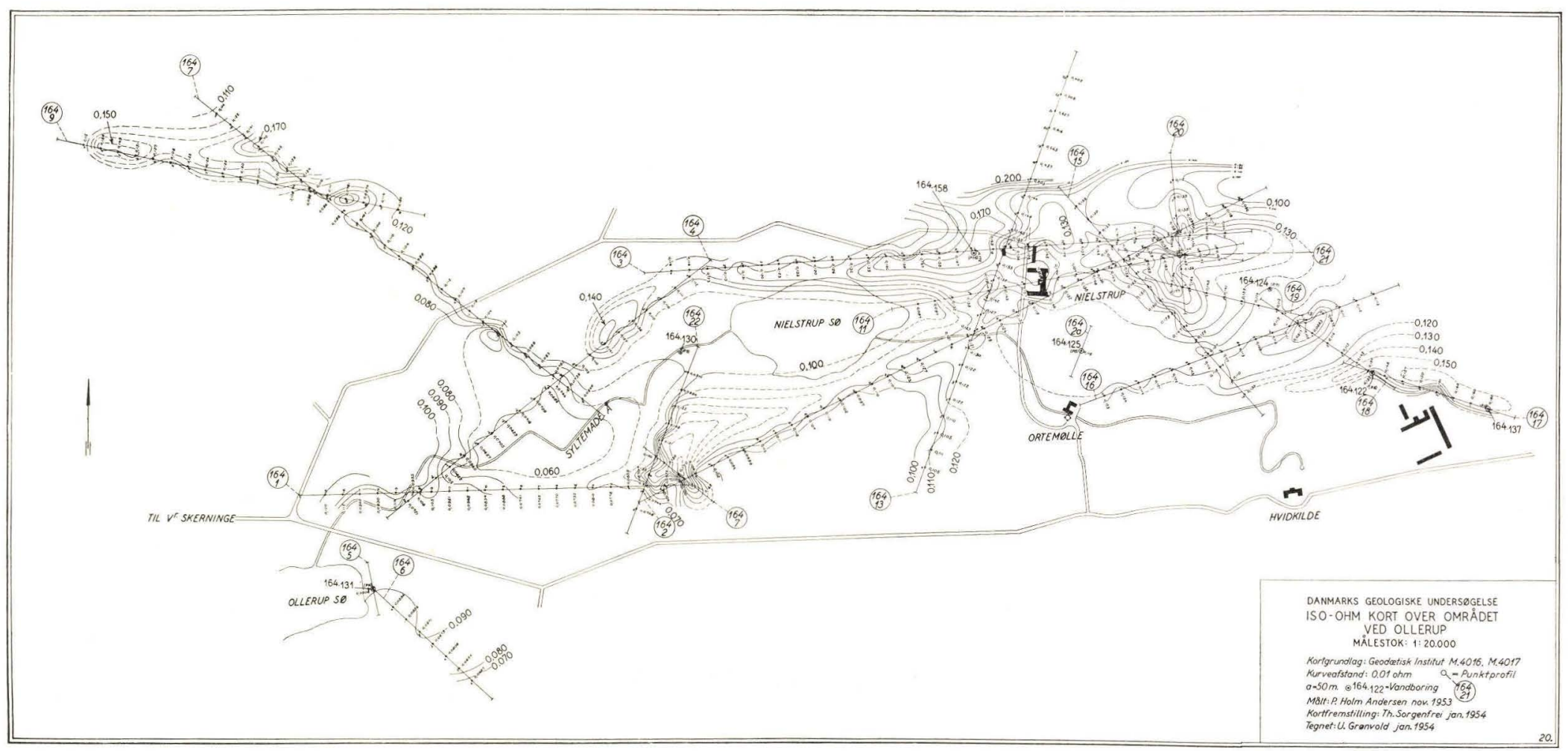

Fig. 42. Ollerup. Iso-ohm map, $a=50 \mathrm{~m}$ contour interval $0.01 \Omega$. Scale 1:20 000 . 


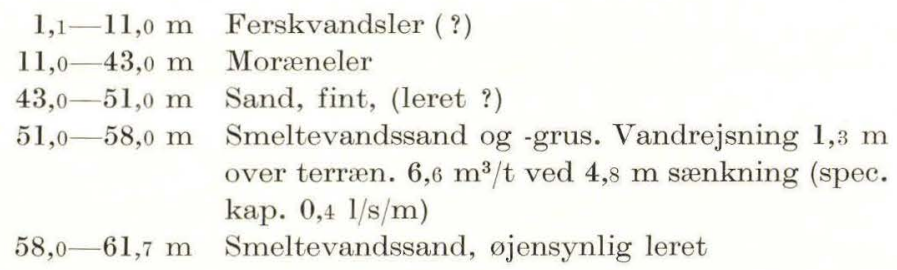

Arkiv nr. 164.137. Hvidkilde. Svendborg vandværks prøveboring P.13, Ø for Hvidkilde. Udført af V. StoffregenN, okt.-sept. 1953.

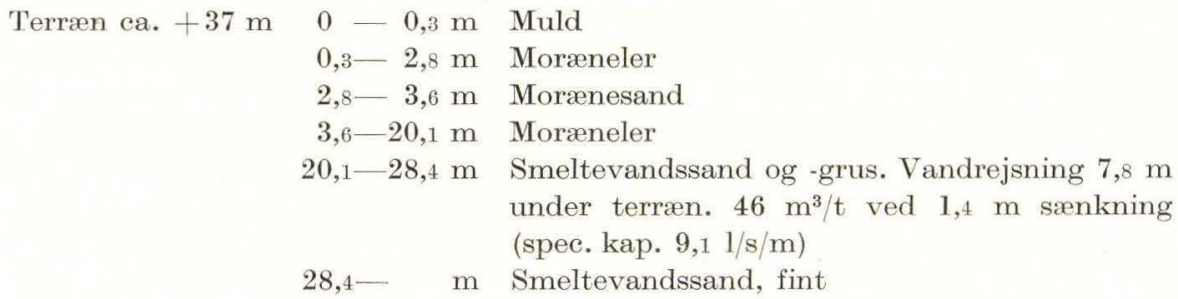

Dalen, hvori boringerne P.7, P.8, P.9 og P.14 er udført, og hvor bl. a. gården Nielstrup ligger, danner sammen med dalen syd for Hvidkilde et tunneldalsystem, som hovedsagelig har retningen øst-vest (se f. eks. V. Milthers 1948).

Af ovennævnte boringer fremgår, at istidsjordlagene er ret varierende. De indeholder nederst en formodet interglacial lerserie uden synderligt betydningsfulde sand- og gruslag. Istidsjordlagene underlejres af Kertemindeler og bryozokalk, som det fremgår af boring P.9 midt i Åmosen. Bryozokalken indeholder saltvand.

Ved vandindvindingen er man således udelukkende henvist til kvartære sand- og gruslag, og dette vil i praksis sige, at interessen først og fremmest må samle sig om lagene over det formodede interglaciale ler.

De geoelektriske undersøgelser. I et tilfælde som det foreliggende, hvor der ønskes indvundet relativt store vandmængder, vil det være naturligt at koncentrere anstrengelserne med henblik på opsporing af vandførende lag om topografisk lavtliggende områder, hvortil der må antages at ske en naturlig tilstrømning af grundvand. I overensstemmelse med dette synspunkt blev der foreslået en linieprofilundersøgelse med $a=50 \mathrm{~m}$ i dalen fra Ollerup til øst for Hvidkilde, idet enkelte linier dog kom til at gå over omkringliggende bakkedrag.

Iso-ohm kortet (fig. 42) viser, at det ved undersøgelsen fra 4/11-7/12 1953, lykkedes at afgrænse forskellige maxima og minima. Som ved undersøgelserne på Tåsinge, Lemvig o. s. v. tolkes et maximum som udtryk for sand- og gruslag, mens et minimum fortrinsvis opfattes som lerområde, forudsat at de terrænmæssige forhold ellers er ens.

Iso-ohm kortet taler stort set for sig selv. Liniernes dækningsgrad har 
af forskellige, navnlig terrænmæssige, årsager ikke kunnet gøres ensartet. Det ses, at de bedste boringer med forholdsvis højtliggende sand- og gruslag ligger i tilknytning til et modstandsmaximum, $\mathrm{N} \varnothing$ for Hvidkilde. Dets udbredelse er ikke undersøgt tilstrækkeligt.

De negative boringer ligger alle i områder med ringe modstand. Som et resultat af interesse kan lokaliseringen af to modstandsmaxima, et vest $\mathrm{og}$ et øst for Nielstrup noteres. De er i dette tilfælde tolket som sandog grusforekomster, idet de findes i lavtliggende terræn. Det er anbefalet at udføre boringer disse steder.

Det er af betydning for opfattelsen af de geologiske og hydrologiske forhold, at der er konstateret meget lave modstandsværdier over det lille bakkedrag, som nord for Hvidkilde strækker sig fra Dyrehave østpå. Bakkedraget består derfor formodentlig fortrinsvis af ler, og der er således grund til at antage, at de to dalstrøg nord og syd for bakkerne ikke er særligt intimt forbundet ved sand- og gruslag.

Svendborg vandværk har efter undersøgelserne udført en boring ca. $100 \mathrm{~m}$ vest for Nielstrup i det kortlagte område med stor modstand. Boreprofilet for denne boring skal anføres:

Arkiv nr. 164.158. Nielstrup. Svendborg vandværks prøveboring P.15, ca. $100 \mathrm{~m} \mathrm{~V}$ for Nielstrup. Udført af V. Stoffregen, Silkeborg febr.-apr. 1954.

\begin{tabular}{|c|c|c|}
\hline Terræn ca. $+19 \mathrm{~m}$ & $\begin{array}{r}0-1,2 \mathrm{~m} \\
1,2-4,3 \mathrm{~m} \\
4,3-6,7 \mathrm{~m} \\
6,7-12,0 \mathrm{~m} \\
12,0-14,1 \mathrm{~m} \\
14,1-19,4 \mathrm{~m} \\
19,4-20,1 \mathrm{~m} \\
20,1-28,5 \mathrm{~m} \\
28,5-30,0 \mathrm{~m} \\
30,0-32,8 \mathrm{~m} \\
32,8-51,0 \mathrm{~m}\end{array}$ & 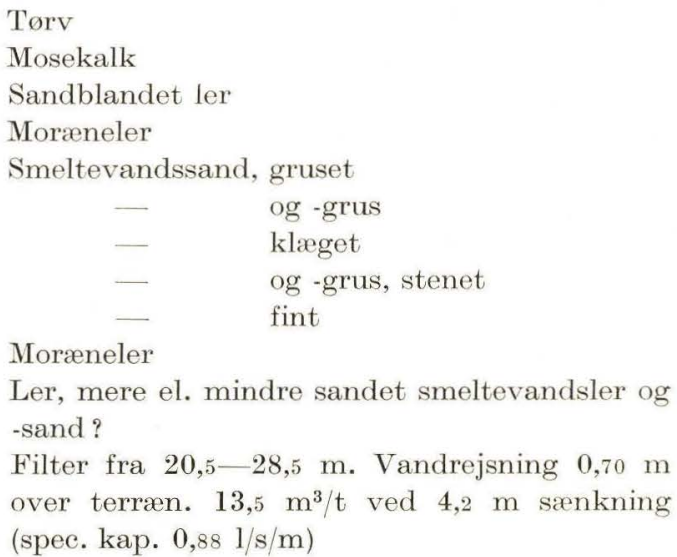 \\
\hline
\end{tabular}

Boringen viser således en god bekræftelse på den givne geologiske fortolkning, selv om ydeevnen af de vandførende lag i dette tilfælde ikke er af nogen betydelig størrelsesorden set ud fra vandværkets ønsker. Der er endnu ikke udført nogen boring i maximet $\varnothing$ for Nielstrup. Der opmåltes dog et punktprofil i den nordlige udkant af maximet ( $\mathrm{nr} .164 .21)$, hvoraf det fremgik, at det pågældende sted formodentlig ligger udenfor den antagne grusforekomst, idet de konstaterede modstande til en dybde af $64 \mathrm{~m}$ kun når op i nærheden af $60 \Omega \mathrm{m}$, hvorefter modstanden synker til 


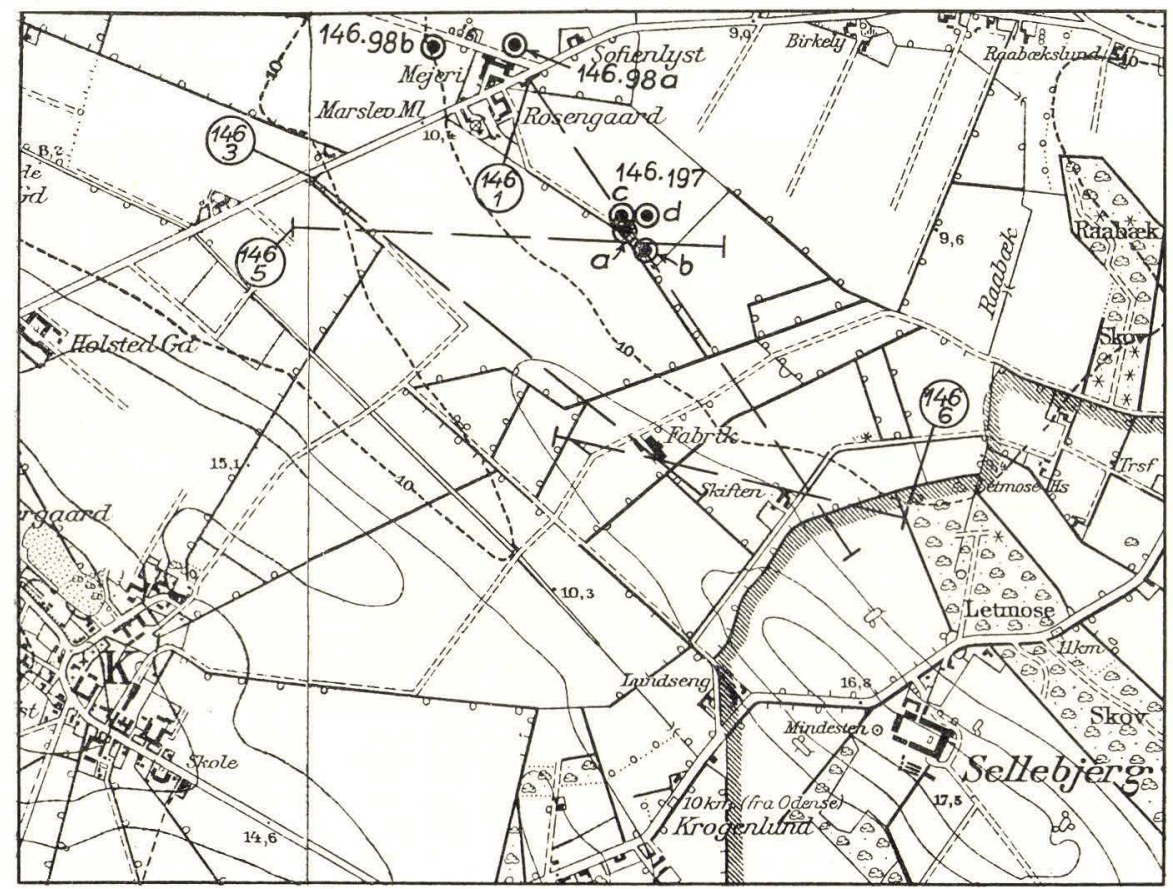

Fig. 43. Marslev . Linieprofiler og boringer. Autoriseret reproduktion, Geodætisk Institut, M 3616 og 3617. 1:20000.

Location of trenching lines and wells. Scale $1: 20000$.

ca. $3 \Omega \mathrm{m}$ hvilket sandsynligvis må tolkes som interglaciallerets eller Kertemindelerets modstand. Leret med den lille modstand skulle altså begynde ved $64 \mathrm{~m}$ dybde.

13. Marslev. Marslev mejeri ønskede at udvide sin vandindvinding i 1953. Mejeriet henvendte sig $\mathrm{i}$ den anledning til D.G.U. om assistance ved placeringen af vandboringerne, som man agtede at udføre i den forbindelse.

De geologiske forhold. Der er tidligere boret umiddelbart ved mejeriet til 69,5 $\mathrm{m}$ dybde (arkiv $\mathrm{nr}$. 146.98.a, se kortet fig. 43). Kvartæret indeholder fortrinsvis moræne. Vandførende sandlag, som findes ved 9,0 og 32,0 $\mathrm{m}$ dybde, udnyttes til vandindvindingen ved mejeriet. Det lykkedes ikke at genfinde disse lag ved en boring, som udførtes ca. $150 \mathrm{~m}$ vest for den gamle boring efter D.G.U.'s anbefaling (arkiv nr. 146.98.b). Kvartæret năr i denne boring ned til ca. $35 \mathrm{~m}$ og derefter følger paleocænt Kertemindeler. Kertemindeleret indeholder i visse intervaller skiferlag, der er vandførende. Ydelsen er dog forholdsvis ringe, og ved den nye boring viste det sig endvidere, at vandet fra $46 \mathrm{~m}$ dybde er saltholdigt. Yderligere vandeftersøgning 


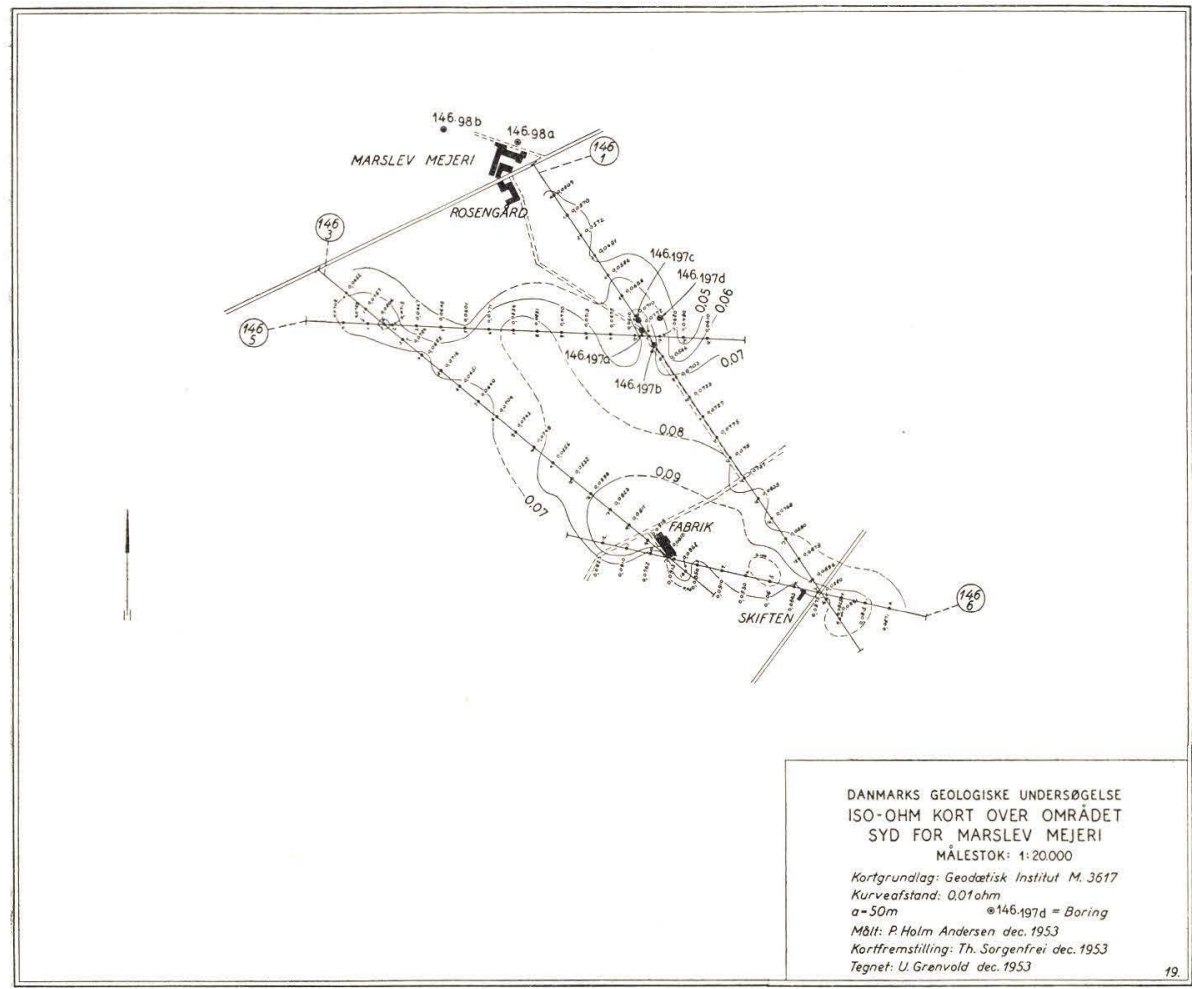

Fig. 44. Marslev. Iso-ohm map, $a=50 \mathrm{~m}$, contour interval $0.01 \Omega$. Scale $1: 20000$.

måtte således tage sigte på at lokalisere sand- og gruslag i kvartæret. Mejeriet anmodede på dette tidspunkt D.G.U. om at foretage en geoelektrisk undersøgelse af et egnet område ved mejeriet.

De geoelektriske undersøgelser. Der opmåltes linieprofiler med $a=50 \mathrm{~m}$ langs linier i terrænet syd for mejeriet, idet to linier med retningen ca. NV-SØ dannede hovedskelettet i undersøgelsen, forbindelseslinier etableres derefter igennem lokale maxima på disse målelinier (se kortet fig. 43).

Iso-ohm kortet (fig. 44) viser resultatet af opmålingerne.

Da der er tale om et meget jævnt, nærmest fladt terræn, der strækker sig langt udenfor kortlægningsområdet, er det rimeligt at gå ud fra, at grundvandspejlet stort set ligger i samme dybde under opmålingsfeltet. Resistivitetsanomalier må derfor først og fremmest tilskrives jordlagenes sammensætning og kornstørrelse. Overensstemmende hermed fortolkedes det brede maximum mod syd som udtryk for tilstedeværelsen af sand- og gruslag med en vis tykkelse. 
Med hensyn til områdets værdi som vandindvindingsområde gradueredes maximet på den måde, at det mod syd, hvor de største værdier måltes, betegnedes som værende af lste grad i midten af nordlige tværlinie af 2 den grad, mod vest på samme linie af 3 die grad, og mod øst på denne linie af 4 de grad.

Ved etableringen af et vandindvindingsanlæg spiller afstanden til oppumpningsstederne af hensyn til nedgravningen af ledningen som bekendt en ganske betydelig økonomisk rolle. Mejeriet besluttede derfor at bore $\mathrm{i}$ det sidstnævnte af de 4 områder.

Der er siden ialt udført 4 boringer her med følgende jordprofiler:

Arkiv nr. 146.197.a. Marslev mejeri. $6^{\prime \prime}$ boring $\mathrm{nr} .1$; $20 \mathrm{~m} \mathrm{NV}$ for krydsningspunktet for linierne $146.1 \mathrm{og}$ 146.5. Udført af firmaet "NEPTUN《, Nyborg jan. 1954 .

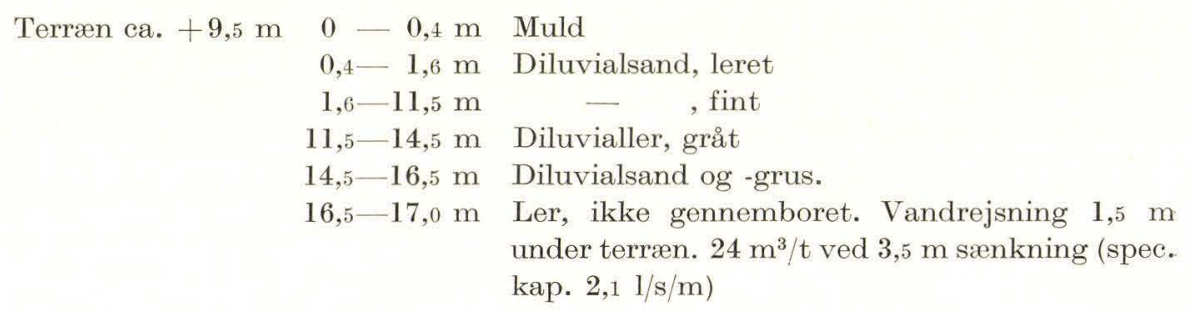

Arkiv nr. 146.197.b. Marslev mejeri. Boring nr. 2; $20 \mathrm{~m}$ SØ for krydsningspunktet mellem linierne $146.1 \mathrm{og}$ 146.5. Udført af firmaet 》NEPTUN《 jan. 1954.

$\begin{array}{ccl}\text { Terræn ca. }+9,5 \mathrm{~m} \quad 0-1,2 \mathrm{~m} & \text { Ler, forvitret, sandet } \\ & 1,2-7,0 \mathrm{~m} & \text { Diluvialsand, fint, gråt } \\ 7,0-30,5 \mathrm{~m} & \text { Moræneler }\end{array}$

Arkiv nr. 146.197.c. Marslev mejeri. 8" boring nr. 3; $40 \mathrm{~m} \mathrm{NV}$ for krydsningspunktet for linierne 146.1 og 146.5. Udført af firmaet »NEPTUN vinteren 1954 . (Ingen prøver modtaget).

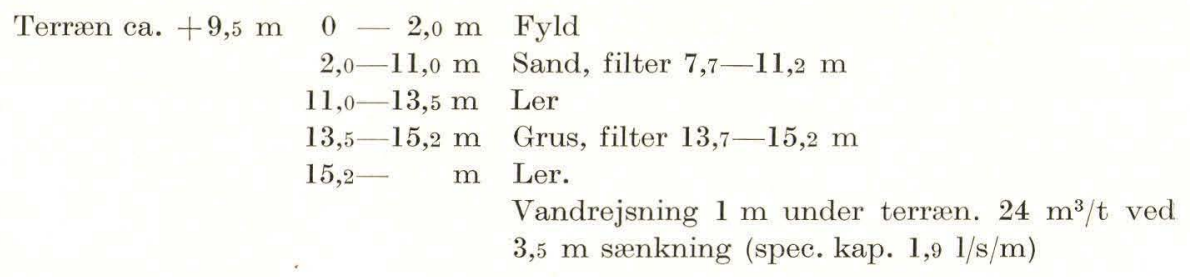

Arkiv nr. 146.197.d. Marslev mejeri. $6^{\prime \prime}$ boring $\mathrm{nr} .4 ; 40 \mathrm{~m} \mathrm{N \varnothing}$ for boring 1. Udført af firmaet "NEPTUN« vinteren 1954. (Ingen prøver modtaget).

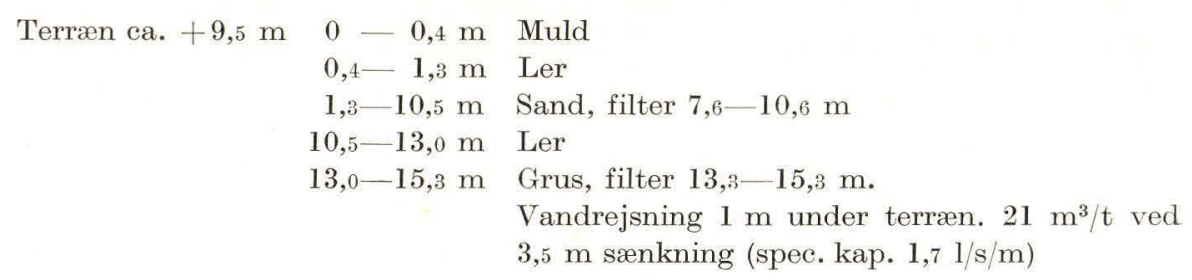


Mejeriet ønskede en vandmængde på ca. 50-60 $\mathrm{m}^{3} / \mathrm{t}$. Da denne mængde kunne oppumpes af boringerne $1,3 \mathrm{og} 4$ indstilledes borearbejdet. De udførte boringer bekræftede således øjensynlig den geologiske fortolkning af modstandsmålingerne.

\section{Oversigt over undersøgelsernes resultater.}

De geoelektriske undersøgelser, som er udført af D.G.U. i 1953 i Danmark og Skåne viser, at man også i dette område ved omhyggelig geologisk og hydrologisk planlægning vil kunne drage fordel af denne meget adaptive geofysiske metode ved undersøgelsen af forskellige objekter under jordoverfladen. At metoden kan få praktisk betydning selv i et terræn med en kompliceret opbygning, som det danske istidslandskab har, i sammenligning med de af fysikerne opstillede idealtilfælde for måleteorien — viser de opnåede resultater ved Landet, Ảbenrå, Ollerup og Marslev.

Der synes ikke at herske tvivl om, at kombinationen af linie- og punktprofiler er den rigtige vej at gå i langt de fleste tilfælde. Man må gøre sig klart, at man meget nemt kan komme ud for forstyrrende jordlagskombinationer, hvis man f. eks. udelukkende arbejder med punktprofilopmåling, som i mange tilfælde ellers synes mest tilfredsstillende.

Antallet af punktprofiler er endnu alt for lille til, at man kan få et sikkert overblik over de forskellige jordlags specifike modstande, og for de i 1953 målte punktprofiler gælder endvidere, at den geologiske kontrol i de fleste af tilfældene er for ringe. Betragter man selve talmaterialet fra punktprofilerne synes der imidlertid at gøre sig visse hovedtræk gældende. For at anskueliggøre disse er de udregnede specifike modstande og de formodede tilsvarende aflejringer sammenstillet i nedenstående skema. Det er dog klart at de anførte værdier må betragtes med et vist forbehold. 
Specifike modstande i $\Omega$ m (ca.) for en række danske aflejringer (Specific resistivities of some Danish deposits in $\Omega m$ (approx.))

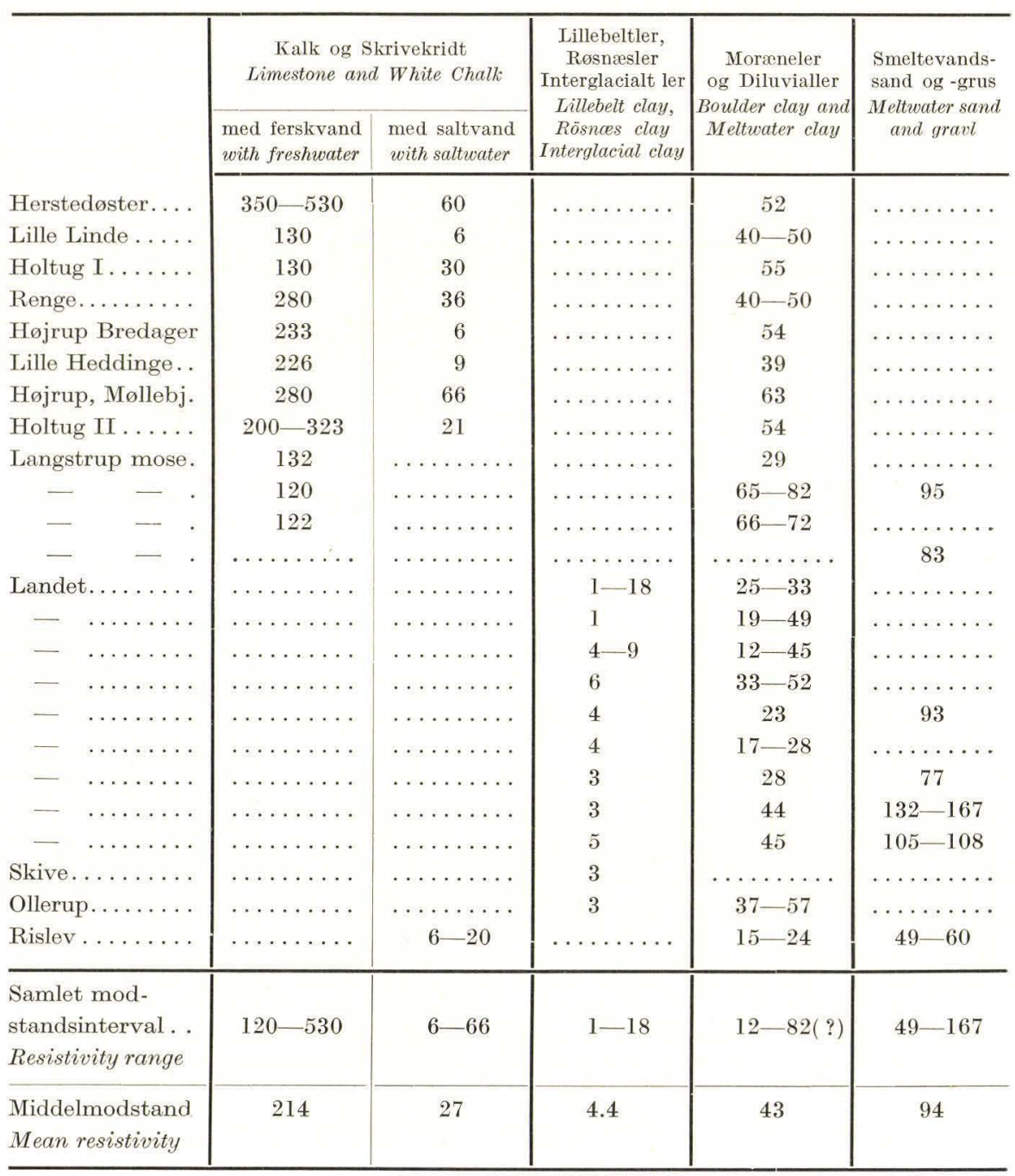




\section{SUMMARY}

\section{Geoelectric Surveys in Denmark and Scania 1953.}

The introduction p. 8 is a brief outline of the main branches of applied geophysics and their field of application viz. 1. magnetic, 2. gravity, 3. seismic, and 4 electric methods.

The subsurface conditions affecting resistivity are dealt with, and the significance of the rocks and their porosity, the content of moisture in the interstices of the rocks, and the salt concentration in the moisture is mentioned.

The low resistance of clays is discussed in more detail. The author favors the concept of the low resistance of clays being related to the ion exchange capacity of the clay minerals. The clay minerals have as is well known the property of sorbing certain cations, but these cations are on the other hand ionized in a clay-water system, ionization depending on the clay minerals involved, size of mineral grains, water content of the rock, nature of cations, their relative concentration, and the nature of adsorbed anions (GRIM 1953, p. 134 etc.). Electrolytic conduction should accordingly be an outstanding feature of a clay-water (or shalewater) system. Future laboratory investigations on the ion exchange capacity and the conductivity of various clays should throw more light upon the relationships between these properties.

The WenneR-method of measuring resistivity is discussed briefly, and formulas derived by Wenner, Hummel, and TAGG are demonstrated on pp. 12-22. The quantitative interpretation of the resistivity curves obtained in Denmark during the measurements carried out in 1953 is also dealt with in this section. Interpretation diagrams elaborated by HeLMER Hedström, chief engineer of A-B Elektrisk Malmletning, Stockholm were very kindly placed at the writer's disposal by Mr. Hedström (fig. 4-5, p. 18-19). The quantitative interpretations have been carried out by means of these diagrams, the basic theories of which were evolved by Hedström in 1926.

The final section of the first part of the paper dealing with fundamentals in earth resistivity measurements discusses the influence of heterogeneities in the subsurface upon equipotential surfaces and lines of current flow (acc. to SCHLUMberger). 


\section{The investigations in 1953.}

A. Instrument and working programme. The instrument used is "Earth Resistivity Meter type 766 no. 19" manufactured by A-B Elektrisk Malmletning, Stockholm (fig. 8). It includes a current supply unit with a hand-driven generator which develops an $\mathrm{AC}$ voltage of about $125 \mathrm{~V}$ and of about 16 cycles at a turning speed of about 40 r.p.m. The resistor arrangement covers the following ranges: $0-0.1 ; 0-1.0$; $0-10.0 ; 0-100 ; 0-1000$ and $0-10000$ ohms. Readings can be obtained down to $0.01 \mathrm{ohm} \pm 3 \%$ (or less). The field equipment includes cables and steel electrodes and the following items: steel measuring tapes, pegs, note books, and maps in the scale of 1:20000 and 1:5000. The transport of equipment and personel took place in a "Volkswagen Kleinbus". The field party consisted of a party chief and three to four assistants.

The programme for the investigations to be carried out by the Geological Survey was put up in the following way:

1. Measurement of resistivity in geologically well known areas according to the WENNER method with expanding electrode spacing ("electrical drilling"), and measurements with constant electrode spacing along straight lines ("trenching"). The objectives should be the following:

a. Electrical drilling. Determination of: 1. depth to groundwater table, 2. specific resistivity of various deposits and rocks, and 3 . depth to formation boundaries.

b. Trenching. Investigation of the possibilities for mapping of: 1. glacial deposits of the Quaternary, 2. saltwater occurrences, and 3. bed-rock topography.

2. Measurements according to the above-named procedures in areas where the geo-hydrologic situation is more or less unknown, but where planned trial bores for water would offer the opportunity of later control of the interpretation of the resistivity surveys. The subjects as mentioned under 1 should be investigated if possible.

It had to be anticipated that the complex bedding of the glacial deposits would prove a serious obstacle for the interpretation of resistivity measurements in Denmark. Difficulties were particularly expected at the interpretation of the electrical drilling curves, since uniformity regarding horizontal bedding over an areea of $5-6 a^{1}$, could scarcely be expected over a great many of the moraine landscapes of the country, provided $a$ would be of a certain magnitude. This was the background for selecting as even grounds as possible for the investigations mentioned under 1 .

Electrical drillings were partly carried out in areas of relatively uniform deposits independently of the mapping with trenchings. However,

1) $a=$ electrode spacing. 
in most cases electrical drillings and trenching grids were combined in order to get the best control of the glacial deposits. The electrode spacing was chosen in accordance with the particular geo-hydrologic problems involved in the different areas. Places in which the groundwater table was near the surface or under artesian pressure were generally preferred as investigation grounds in order to avoid the potential strong effect of high resistivity deposits above the groundwater table upon the trenching values. The resistivity values obtained in such areas would thus practically only reflect the variation of rock and groundwater properties. Contour maps drawn on the basis of the trenching resistances were intended in order to outline the horizontal variation of resistivity, and to locate resistivity anomalies. Electrical drillings were thence carried out over significant anomalies or in areas in which uniformity of deposits was suggested by the trenching values.

The selection of investigation areas was done on the basis of the information on well data kept in the files of the Well Record Department of the Geological Survey. Party chiefs in the field were: P. Holm AxDersen $(2 / 16-5 / 20$ and $11 / 4-12 / 16)$. N. V. Jessen and B. Micheelsen (both last-named 7/15-10/24). Curves and maps were drawn by Mrs. U. Andersen, Mrs. R. Rasmussen, and Miss I. Petersen. Interpretation and calculations have been carried out by the present author.

The trenching lines and the location of the electrical drillings were entered on maps in the scale of 1:20000, and the iso-ohm maps were drawn in the scale of 1:5000. These were again reduced to the scale of $1: 20000$ on the blocks which were prepared for this paper. The iso-ohm. maps which originally were drawn as progress maps show $R$ values and not $\varrho$ values (see formula (4) p. 14). The $R$ values on the maps corresponding to an electrode spacing of $25 \mathrm{~m}$ have thus to be multiplied by 157 and those on the maps corresponding to a spacing of $50 \mathrm{~m}$ have to be multiplied by 314 in order to express the apparent resistivity in ohm meters.

The figures at the end of the trenching lines and at the measuring point of the electrical drillings shown on the maps are file numbers.

Each measuring station on the trenching lines is supplied with a station number and the resistance value obtained during the survey.

\section{B. The Geo-electric Surveys.}

1. Herstedöster $\left.{ }^{1}\right)$. Electrical drilling in level and uniform moraine area $W$ of Copenhagen (fig. 11, p. 27; table I fig. 1). A drilled section $300 \mathrm{~m} \mathrm{~S}$ of the measuring point displayed the following sequence (Well File No. 200.662).

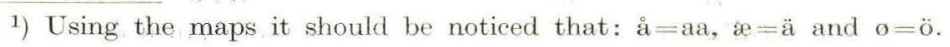


0- $8.9 \mathrm{~m}$ Quaternary, probably moraine clay

$\left.\begin{array}{rl}\text { 8.9-11.5 m } & \text { Bryozoan Limestone } \\ 11.5-31.4 \mathrm{~m} & \text { Limestone with occasional flint beds }\end{array}\right\}$ Danian Groundwater table about $8.5 \mathrm{~m}$ below surface.

Top of the Danian limestone and of the Senonian White Chalk as well as the level of the groundwater table at the measuring point were interpolated by means of data obtained from this and other wells in the surroundings.

The specific resistivities which were calculated on the basis of the resistivity curve (plate I fig. 1) and the corresponding depth intervals are shown below together with the geologic interpretation and the interpolated levels.

\begin{tabular}{|c|c|c|c|c|}
\hline Depth & $\varrho(\Omega \mathrm{m})$ & Interpretation & & Interpolated levels \\
\hline $0-0.6 \mathrm{~m}$ & 1300 & Soil & & \\
\hline $0.6-11.5 \mathrm{~m}$ & 52 & Moraine clay & $9 \mathrm{~m}$ & Groundwater table \\
\hline $11.5-19.5 \mathrm{~m}$ & 531 & Bryozoan Limestone & & $\begin{array}{l}\text { Top of Bryozoan Lime- } \\
\text { stone }\end{array}$ \\
\hline $19.5-90$ & 352 & and White Chalk & $60 \mathrm{~m}$ & Top of White Chalk \\
\hline $90-? \mathrm{~m}$ & 59 & $\begin{array}{l}\text { White Chalk with } \\
\text { salt water }\end{array}$ & & \\
\hline
\end{tabular}

It appears that the resistivity contrast between the limestone and the glacial deposits is impressive whereas no remarkable contrast is found at the level corresponding to the transition: Bryozoan Limestone-White Chalk. The low resistivity at about $90 \mathrm{~m}$ may indicate the presence of salt water in the Chalk. Such is well known from deep drillings in the Copenhagen area.

2. Lille Linde, Stevns and Karise. (Maps fig. 12-16, p. 28-33). A number of electrical drilling measurements were carried out at Lille Linde and on the Stevns peninsula. The geologic situation is similar to the one at Herstedöster, and many well sections are known from the surveyed areas. Depth and resistivity data are listed below together with interpretation and interpolated levels as in case of Herstedöster. The interpolated levels are entered on plate I, figures $2-8$ (Gr.vsp=groundwater table; Kalkoverfl. $=$ top of limestone; Skrivekr.overfl. $=$ top of White Chalk).

Lille Linde.

File no. 218.1. Lille Linde (plate I, fig. 2).

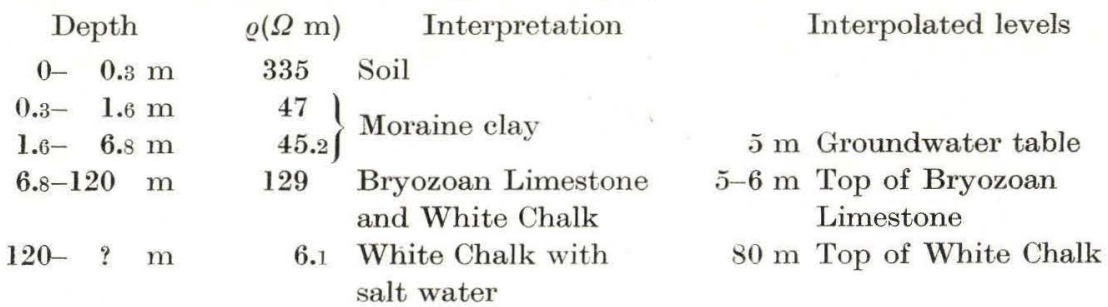


Stevns.

File no. 218.2. Holtug I (plate I, fig. 3).

Depth $\varrho(\Omega \mathrm{m}) \quad$ Interpretation Interpolated levels

$0-0.5 \mathrm{~m} \quad 185$ Soil

$0.5-0.8 \mathrm{~m} \quad 203 \quad$ Sand

$0.8-6.8 \mathrm{~m} \quad 54.8$ Clay $9 \mathrm{~m}$ Bryozoan Limestone

6.8-64 m 128.5 Bryozoan Limestone $12 \mathrm{~m}$ Groundwater table

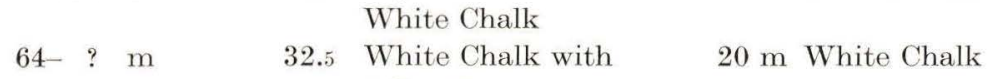

salt water

File no. 218.3. Renge Östergaard (plate I, fig. 4).

Depth $\varrho(\Omega \mathrm{m}) \quad$ Interpretation Interpolated levels

$0-0.5 \mathrm{~m} \quad 78$ Soil

$0.5-1.8 \mathrm{~m}$

$1.8-10 \mathrm{~m}$

$\left.\begin{array}{l}46.7 \\ 49\end{array}\right\}$ Moraine clay

$10-70 \mathrm{~m}$

277 Bryozoan Limestone and White Chalk

$70-? \mathrm{~m}$

36.3 White Chalk with salt water

$8 \mathrm{~m}$ Groundwater table

$9 \mathrm{~m}$ Top of Bryozoan

Limestone

$42 \mathrm{~m}$ Top of White Chalk

Interpolated levels

File no. 218.4. Höjerup (plate I, fig. 5).

\begin{tabular}{|c|c|c|c|}
\hline Depth & $\varrho(\Omega \mathrm{m})$ & Interpretation & Interpolated levels \\
\hline $0-0.8 \mathrm{~m}$ & 215 & Soil & \\
\hline $.8-2.9 \mathrm{~m}$ & 53.7 & Moraine clay & \\
\hline $2.9-5.7 \mathrm{~m}$ & 201 & Sand? & \\
\hline $5.7-80 \quad \mathrm{~m}$ & 233 & $\begin{array}{l}\text { Bryozoan Limestone } \\
\text { and White Chalk }\end{array}$ & $\begin{array}{l}9 \mathrm{~m} \text { Groundwater table and } \\
\text { top of Bryozoan Lmst. }\end{array}$ \\
\hline $80-? \mathrm{~m}$ & 5.55 & $\begin{array}{l}\text { White Chalk with } \\
\text { salt water }\end{array}$ & $28 \mathrm{~m}$ Top of White Chalk \\
\hline
\end{tabular}

File no. 218.5. Lille Heddinge (plate I, fig. 6).

\begin{tabular}{|c|c|c|c|}
\hline Depth & $\varrho(\Omega \mathrm{m})$ & Interpretation & Interpolated levels \\
\hline $0-0.8 \mathrm{~m}$ & 177 & Soil & \\
\hline $0.8-4 \mathrm{~m}$ & 39 & Moraine clay & \\
\hline $4-10$ & 226 & $\begin{array}{l}\text { Bryozoan Lmst. above } \\
\text { groundwater table }\end{array}$ & $5 \mathrm{~m}$ Top of Bryozoan Lmst. \\
\hline $10-74 \mathrm{~m}$ & 215 & $\begin{array}{l}\text { Bryozoan Lmst. and } \\
\text { White Chalk below } \\
\text { groundwater table }\end{array}$ & $25 \mathrm{~m}$ Top of White Chalk \\
\hline $74-? \mathrm{~m}$ & 8.8 & $\begin{array}{l}\text { White Chalk with } \\
\text { salt water }\end{array}$ & \\
\hline
\end{tabular}

File no. 218.6. Höjerup (plate I, fig. 7). Depth $\quad \varrho(\Omega \mathrm{m}) \quad$ Interpretation

$0-0.4 \mathrm{~m}$

$0.4-0.6 \mathrm{~m}$ $\left.\begin{array}{l}162 \\ 243\end{array}\right\}$ Soil

$0.6-6.8 \mathrm{~m}$

63

$6.8-7.2 \mathrm{~m}$

7.2-11 m

198

272

Moraine clay

276 Bryozoan Lmst. and

$11-17 \mathrm{~m}$

White Chalk

$17-60 \mathrm{~m}$

280

White Chalk

Interpolated levels

$60-$ ? $\mathrm{m}$

66 White Chalk with

salt water

$6.5 \mathrm{~m}$ Top of Bryozoan Lmst. $10.5 \mathrm{~m}$ Groundwater table

$30.5 \mathrm{~m}$ Top of White Chalk 


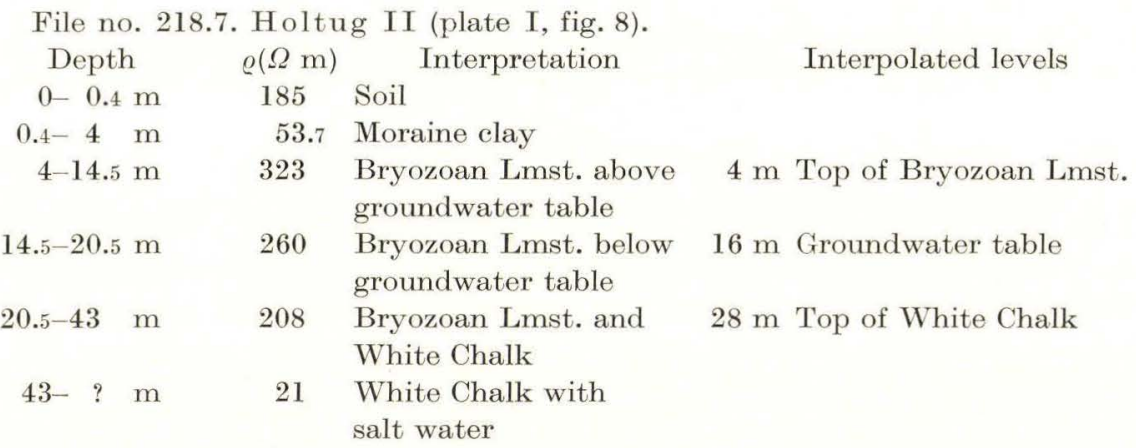

The electrical drillings at Herstedöster, Lille Linde and on Stevns thus evidence a sufficient resistivity contrast between the moraine clay and the Danian limestone as to be reflected by the resistivity curve. The groundwater table would, however, only act as a traceable resistivity discontinuity if the water table is found in the limestone. The lack of a resistivity record of the groundwater table in the locations where the groundwater of the limestone is under pressure, due to a cover of clay may be reasonably explained by the fact that the water table is a mere theoretical concept outside wells in these areas. No sharp resistivity break should accordingly be expected in the clay at this level.

There is no discernible change in resistivity at depths which might correspond to the transition Bryozoan Limestone-White Chalk, and it might therefore be concluded that the resistivities of these rocks are of the same magnitude. The low resistivity at greater depth may only be explained in assuming the presence of salt water in the White Chalk which otherwise may be rather uniform lithologically to depths of several hundred metres. The occurrence of salt water is well known in the region as may appear from the following report on the survey at Karise.

Karise. Trenching 218.8. Traverse line from Kirkbro crossing the stream Stevns å and trending about WNW-ESE, $a=10 \mathrm{~m}$, length of traverse line $560 \mathrm{~m}$. Apparent resistivity about $90-100 \Omega \mathrm{m}$ on average at Kirkbro and E of the stream of Stevns å; minimum value $35.1 \Omega \mathrm{m}, 10 \mathrm{~m}$ $\mathrm{W}$ of the stream (see map fig. 16, and diagram fig. 17, p. 33).

A well about $360 \mathrm{~m} \mathrm{~S}$ to $\mathrm{W}$ of the trenching (file no. 218.354) encountered the Bryozoan Limestone at a depth of $4 \mathrm{~m}$. The limestone contained salt water at a depth of $24 \mathrm{~m}$.

The resistivity minimum on trenching 218.8 is assumed to be related to the occurrence of salt water in the limestone which is suggested to be within the depth range of the trenching, and otherwise should display higher resistivity values.

3. Langstrup. (Maps fig. 18-21, p. 36-39). The bedrock of NESjælland consists of Danian Limestone, which is completely covered by 
Quaternary deposits including a variety of glacial sediments. The bedrock topography has been mapped on the basis of well data, and it has in this way been possible to unveil a burried valley in the limestone which is about $12 \mathrm{~km}$ wide and trends NW-SE. This valley, the Alnarp Valley, was firstly recognized in Scania (ERDMann 1887) from where it was traced to NE-Sjælland (V. MiLthers 1922).

The graben nature of the valley has been evidenced on the basis of the geologic and hydrologic data from numerous wells, and the presence of a normal fault structure has been suggested at the southern border of the valley (Sorgenfrei 1945). The main fault (fig. 18: Hovedforkastning= Main Fault) runs through the bog of Langstrup Mose. The limestone surface is found at about $60 \mathrm{~m} \mathrm{B.D.} \mathrm{N}$ of the fault whereas the limestone rises relatively rapidly to about 40 to $30 \mathrm{~m} \mathrm{B.D.} \mathrm{S} \mathrm{of} \mathrm{the} \mathrm{fault.} \mathrm{The} \mathrm{orig-}$ inal fault scarp was obviously smoothed out during Quaternary time by glacial erosion. The faulting of the valley may have taken place during late Tertiary.

Of particular interest is the occurrence of saline water in the shallow limestone about $500 \mathrm{~m} \mathrm{~S}$ of the suggested main fault at a trend approximately parallel with the fault. This feature has been interpreted by the present author as an indication of an accessory minor fault through which the salt water may ascend from the deep underground. Sand and gravel above the limestone may drain the salt water out of the limestone. It should be added in this connection that the sea is only about $2.5 \mathrm{~km}$ away, and that the groundwater table rises considerably above surface in the wells sunk into the limestone. The polygon of trenching lines shown on fig. 18 encircles the well with the highest salt concentration (about 150 p.p.m. of $\left.\mathrm{Cl}^{-}\right)$.

The area of Langstrup Mose was chosen for the first trenching mapping on a larger scale with the objective of a general reconnaissance of the area. Fig. 18 shows the electrical drilling locations, the traverse lines, and the location of the wells shown on the resistivity diagrams (plate II, fig. 1-4). The electrode spacings applied were: $25 \mathrm{~m}, 33 \mathrm{~m}$, and $50 \mathrm{~m}$.

The iso-ohm maps (fig. 19-21) reveal that the measurements failed to reflect any indication of the fault, which mainly may be attributed the too short electrode spacings.

The resistivity minimum which is outlined on each of the three maps around the well with the highest $\mathrm{Cl}^{-}$content in the water is explained as an effect of the saline water, since the occurrence of sand and gravel in the area should otherwise result in a local resistivity maximum. It is realized that the trenching grid is insufficient for a more detailed interpretation, and a future extension of the survey is accordingly planned.

The electrical drilling results and corresponding interpretations were the following: 
File no. 187.9. Langstrup Mose (plate II, fig. 1).

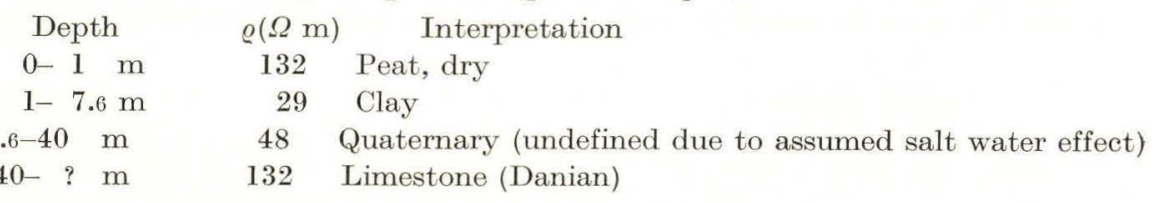

File no. 187.10. Langstrup Mose (plate II, fig. 2).

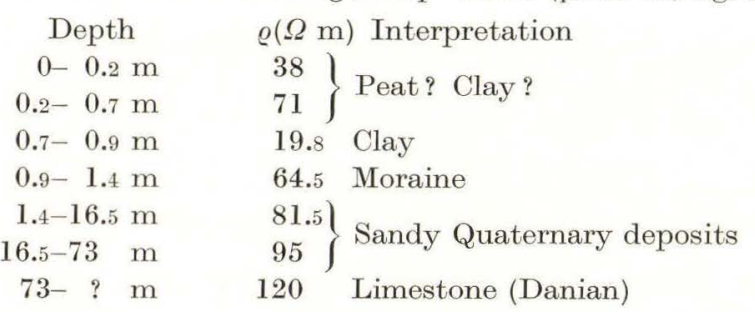

File no. 187.11. Langstrup Mose (plate II, fig. 3).

\begin{tabular}{ccl} 
Depth & $\varrho(\Omega \mathrm{m})$ & \multicolumn{1}{l}{ Interpretation } \\
$0-0.4 \mathrm{~m}$ & 66 & Peat \\
$0.4-3.7 \mathrm{~m}$ & 16.5 & Clay \\
$3.7-7.4 \mathrm{~m}$ & 72 & Argillaceous sand \\
$7.4-36 \mathrm{~m}$ & 65.5 & Mainly moraine \\
$36-125 \mathrm{~m}$ & 121.5 & Limestone (Danian)
\end{tabular}

File no. 187.12. Langstrup Mose (plate II, fig. 4).

\begin{tabular}{|c|c|c|}
\hline Depth & $\varrho(\Omega \mathrm{m})$ & Interpretation \\
\hline $0-2.4 \mathrm{~m}$ & 41 & Clay \\
\hline $4-18 \quad m$ & $76.2)$ & Clays and sands \\
\hline $\begin{array}{l}8-\text { abt. } 60 \mathrm{~m} \\
0-\quad ? \mathrm{~m}\end{array}$ & $\begin{array}{l}83\} \\
85 ?\end{array}$ & Sand and Limstone \\
\hline
\end{tabular}

By comparison of the calculated specific resistivities with the graphic logs of wells adjacent to the electrical drilling points it appears reasonable to relate the resistivities above 50 and below $100 \Omega \mathrm{m}$ in the glacial sequence to sands and gravels. There are, of course, disagreements which, however, are not surprising if the great potential variability of the glacial deposits even over short distances is taken into account, and the distance to the wells concerned is considered.

The resistivity contrast between the Limestone and the Quaternary appears to be satisfactory for calculating the depth to top of the limestone within an error of $2-5 \mathrm{~m}$ (abt. $5-10 \%$ ).

4. Landet, island of Tåsinge. (Maps fig. 22-23, p. 40-41) Inhabitants of three villages on Tåsinge decided to establish a co-operative waterworks at Landet. The engineer in charge of the establishment accordingly enquired 
the Well Record Department of The Geological Survey regarding a drilling location. It was recommended to drill at a suitable place on low elevation in the valley in which the villages are situated and which crosses the island from SE to NW.

The valley is assumed to have originated as a subglacial tunnel valley during the last glaciation, and it might, therefore, be suggested that gravel and sand should be present somewhere in the subsurface Pleistocene deposits of the valley. It was the scope to locate such permeable beds which might well act as aquifers. The proposed drilling programme included drilling to be discontinued as soon as Tertiary clays were encountered. Further drilling would thence be useless due to the absence of aquifers in the Tertiary beds and the presence of salt water in the Danian limestone below.

Three wells were drilled in different places as shown on the map fig. 22 , p. 40 (file no. 164.135 a \& b; 172.30 a) but they proved all dry, and in each case they displayed practically the same sequence: a series of Boulder clays resting on sticky Lillebelt clay or Rösnæes clay of the Eocene. The Eocene beds were encountered at about $40 \mathrm{~m}$ below surface.

The subsequently planned resistivity survey included electrical drilling at each of the dry holes and a resistivity mapping of the Glacial Drift using an electrode spacing of $50 \mathrm{~m}$ and covering about $1_{\frac{1}{2}}$ square kilometres of the valley bottom.

Very low resistivity values were obtained in the area, and it is obvious from the resistivity curves that the Tertiary Lillebelt and Rösnæs clays have very low resistivities. The results from the electrical drillings were the following:

File no. 164.1. Landet (plate III, fig. 1).

\begin{tabular}{|c|c|c|}
\hline Depth & $\varrho(\Omega \mathrm{m})$ & Interpretation \\
\hline $0-0.4 \mathrm{~m}$ & 100 & Soil \\
\hline $0.4-4.2 \mathrm{~m}$ & 331 & \\
\hline $4.2-35 \mathrm{~m}$ & $25.2\}$ & Morame cla \\
\hline $35-47$ & 0.52 & Lillebelt clay \\
\hline $47-?$ & 18.6 & Rösnæes clay? \\
\hline
\end{tabular}

File no. 164.2. Landet (plate III, fig. 2).

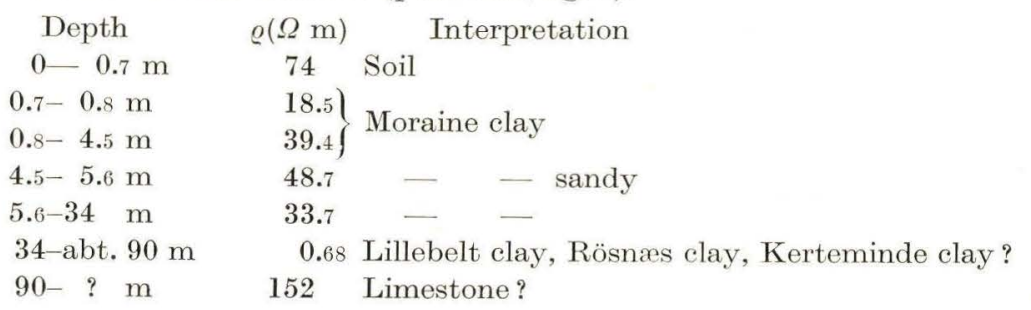


File no. 164.6. Landet-Strammelse (plate III, fig. 3).

Depth $\varrho(\Omega \mathrm{m}) \quad$ Interpretation

$0-0.7 \mathrm{~m} \quad 250 \quad$ Soil

$0.7-3.8 \mathrm{~m} \quad 27.5$ Moraine clay

3.8-24 m $\quad 77$ Sand, gravel and clay

$24-27.5 \mathrm{~m} \quad 3.4$ ) Lillebelt clay

$27.5-$ ? $\mathrm{m} \quad 14\}$ and Rösnæs clay

File no. 172.1. Lundby (plate III, fig. 4).

Depth $\quad \varrho(\Omega \mathrm{m}) \quad$ Interpretation

$0-0.6 \mathrm{~m} \quad 175$ Soil

$0.6-0.9 \mathrm{~m} \quad 94.5$ Sandy moraine clay

$0.9-7.1 \mathrm{~m}$

$7.1-8.9 \mathrm{~m}$

$8.9-22.0 \mathrm{~m}$

$22.0-39.0 \mathrm{~m}$

$39.0-$ ? $\mathrm{m}$

44.5

$\left.\begin{array}{l}12 \\ 20\end{array}\right\}$ Moraine elay

$\left.\begin{array}{l}4.0 \\ 9.4\end{array}\right\}$ Lillebelt clay

File no. 172.2. Lundby (plate III, fig. 5).

$\begin{array}{ccc}\text { Depth } & \varrho(\Omega \mathrm{m}) & \text { Interpretation } \\ 0-0.2 \mathrm{~m} & 40 & \text { Soil } \\ 0.2-1.0 \mathrm{~m} & 26.7 & \text { Moraine clay } \\ 1.0-1.75 \mathrm{~m} & 52.2 & - \\ 1.75-10.5 \mathrm{~m} & 33.2 & - \\ 10.5-\text { abt. } 40 \mathrm{~m} & 5.8 & \text { Lillebelt clay } \\ 40-? \mathrm{~m} & 250 & \text { ? }\end{array}$

File no. 172.3. Lundby.

$\begin{array}{ccl}\text { Depth } & \varrho(\Omega \mathrm{m}) & \text { Interpretation } \\ 0-2.4 \mathrm{~m} & 31 & \text { Soil and moraine clay } \\ 2.4-5.4 \mathrm{~m} & 93 & \text { Sand } \\ 5.4-15.5 \mathrm{~m} & 23 & \text { Moraine Clay } \\ 15.5-93 \mathrm{~m} & 3.9 & \text { Lillebelt clay } \\ 93-? \mathrm{~m} & 0.24 \quad ?\end{array}$

File no. 172.4. Lundby (plate III, fig. 6).

\begin{tabular}{|c|c|c|}
\hline Depth & $\varrho(\Omega \mathrm{m})$ & Interpretation \\
\hline $0-0.5 \mathrm{~m}$ & 37 & Soil and moraine clay \\
\hline $0.5-0.7 \mathrm{~m}$ & abt. 45 & soll and moraine clay \\
\hline $0.7-9 \mathrm{~m}$ & 28 & Morgine elox \\
\hline $9-23.5 \mathrm{~m}$ & $17.4 \int$ & Mrorame clay \\
\hline $3.5-$ ? $\mathrm{m}$ & 3.6 & Lillebelt clay \\
\hline
\end{tabular}

File no. 172.6. Landet (plate III, fig. 7).

\begin{tabular}{|c|c|c|}
\hline Depth & $\varrho(\Omega \mathrm{m})$ & Interpretation \\
\hline $0-0.5 \mathrm{~m}$ & 137 & Soil and sand \\
\hline $0.5-1.1 \mathrm{~m}$ & 167 & \\
\hline $1.1-2.7 \mathrm{~m}$ & 165 & Sand and gravel \\
\hline $2.7-13 \mathrm{~m}$ & 132 & \\
\hline 13-abt. $34 \mathrm{~m}$ & 43.5 & Clay \\
\hline $34 \quad ? \mathrm{~m}$ & 3.1 & Lillebelt clay \\
\hline
\end{tabular}


File no. 172.9. Landet (plate III, fig. 8).

\begin{tabular}{|c|c|c|}
\hline Depth & $\varrho(\Omega \mathrm{m})$ & Interpretation \\
\hline $0-1.5 \mathrm{~m}$ & 24 I & \multirow{2}{*}{ Soil and clay } \\
\hline $1.5-4.7 \mathrm{~m}$ & 44.8 J & \\
\hline $4.7-12 \mathrm{~m}$ & 105 & \multirow{2}{*}{ Sand and gravel } \\
\hline $12-25 \mathrm{~m}$ & $108 \int$ & \\
\hline $25-76$ & 5.3 & Lillebelt clay \\
\hline $76-\quad ?$ & 280 & $?$ \\
\hline
\end{tabular}

The iso-ohm map fig. 23 displayed two maximum anomalies, one over elevated ground on the northern slope of the valley with the highest resistivity values and another one on the bottom of the valley $\mathrm{N}$ of Landet church. The last-named was interpreted as suggestive of gravel and sand accumulations in the Glacial Drift. The possibility of the high resistivity being indicative of partly dry beds above the groundwater table could be disregarded since the valley is very level over the area concerned, and the groundwater table might be assumed to be very near to the surface.

It was finally recommended to drill a well in the center of this anomaly. The graphic log of the well is shown opposite the resistivity curve on plate III, fig. 8. The sands and gravels encountered proved waterbearing with the water table at surface. The yield of the well was $10 \mathrm{~m}^{3} / \mathrm{h}$ at a water table depression of $3 \mathrm{~m}$ which was a sufficient amount for the waterworks planned.

5. Ängelholm. (Scania). (Maps fig. 24-25, p. 46-47). A resistivity survey was carried out during $5 / 6-5 / 71953$ at the pumping station St. Brandsvig of Ängelholm waterworks in cooperation with civil engineer G. Weijuan-Hane of Chalmer's Technical Highschool, Gotenburg, and his research students Mr. Ingvar Hörberg and Mr. KarL-AxeL KäLLSTRAND.

The shallow subsurface of the area consists of about $20-50 \mathrm{~m}$ of glacial clay at the base of which melt-water sands and gravels may occasionally occur. Moraine deposits follow below until depths of about 120-130 m where they are underlaid by shales, sandstones, and coal beds of the Rhaet-Lias formation.

Ditch samples from the drillings I-II were kept at the pumping station, they were investigated by the present author during the stay at Ängelholm, and compared with the well logs which are copied on plate II, fig. 5-6.

The resistivity survey included three trenchings with $50 \mathrm{~m}$ of electrode spacing and two electrical drillings, one at well II and one on traverse line file no. 12.4 .

The iso-ohm map drawn (fig. 25) illustrates maximum resistivities around well I. It is assumed that shallow sands are responsible for this maximum. The results of the mapping shows further the significance 
of distance to the beds of high resistivity insofar as the coarse gravels at well II have a lesser effect on the apparent resistivity than the shallower sands around well I, in spite of the apparently much greater yield of water from the gravel beds in well II.

The computed specific resistivities and corresponding interpretations are listed below.

File no. 12.2. Ängelholm. Well II (fig. 39).

\section{Solution A Solution B}

\begin{tabular}{|c|c|c|c|c|c|}
\hline Depth & $\varrho(\Omega \mathrm{m})$ & Depth & $\varrho(\Omega \mathrm{m})$ & & Log of well II. \\
\hline$?-2.9 \mathrm{~m}$ & 40 & $?-1.8 \mathrm{~m}$ & 38 & & \\
\hline $2.9-3.7 \mathrm{~m}$ & 120 & $1.8-3.3 \mathrm{~m}$ & 71 & & \\
\hline $3.7-5.1 \mathrm{~m}$ & 20 & $3.3-4.8 \mathrm{~m}$ & 22 & $0-5 \mathrm{~m}$ & Clay, sandy \\
\hline $5.1-29 \mathrm{~m}$ & 28 & $4.8-29 \mathrm{~m}$ & 28 & $5-27.7 \mathrm{~m}$ & $\begin{array}{l}\text { Clay, sandy and argillaceous } \\
\text { sand }\end{array}$ \\
\hline $29-43$ & 87 & $29-43$ & 87 & $27.7-32.8 \mathrm{~m}$ & Sand and gravel \\
\hline $43-50$ & 12 & $43-50$ & 12 & $32.8-46 \mathrm{~m}$ & $\begin{array}{l}\text { Sand and gravel, argilla- } \\
\text { ceous }\end{array}$ \\
\hline
\end{tabular}

File no. 12.5. Ängelholm. About $130 \mathrm{~m} \mathrm{NW}$ of Well I.

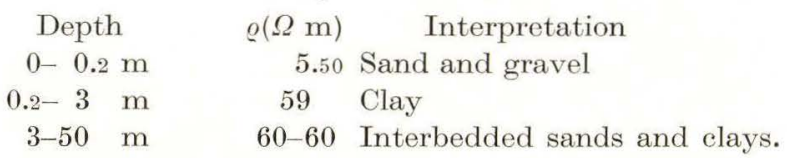

Two solutions are given in case of curve no. 12.2 to show the degree of uncertainty which often is attributed to the quantitative analysis of resitivity curves according to the method applied here.

6. Veberöd. (Scania). (Maps fig. 26-27, p. 48-49). The cooperation with Mr. WeiJman-Hane was continued during a survey of an area around Veberöd waterworks which had previously been thoroughly investigated by WeIJMAN-HANe with respect to the geologic and hydrologic conditions in the shallow subsurface.

An area of gravel and sand deposits of fluvioglacial origin had thus been located, and an estimate of the thickness had been obtained by means of shallow probe holes to depths of about 10-15 m. The prePleistocene is unknown and suggested below $50 \mathrm{~m}$ depth.

The resistivity survey included the following trenchings and corresponding electrode spacings: $13,1(a=15 \mathrm{~m}) ; 13,3(a=10 \mathrm{~m}) ; 13,4(a=$ $15 \mathrm{~m})$. The trenchings were located parallel with the drilled cross-sections $\mathrm{E}-\mathrm{F}, \mathrm{A}-\mathrm{B}$ and $\mathrm{C}-\mathrm{D}$ respectively. Additional electrical drillings were measured at the crossing of sections $\mathrm{A}-\mathrm{B}$ and $\mathrm{E}-\mathrm{F}(13,2)$ and at well $\mathrm{B}_{2}$ (see fig. 26). 
The $\varrho$-values (see formula (4) p. 14) computed from the trenchings have been entered on a map in the scale of 1:2500 and equi-resistivity contours have been drawn subsequently. It should thus be realized that the Q-values are strictly speaking not comparable due to difference in depth penetration of the trenchings. The reason why contours have nevertheless been drawn is that the contour picture may illustrate a fair approximation of the resistivity gradient in the area. If the variation of the resistivities on the traverse lines are compared with the geologic conditions it appears that there is fairly good correlation between the thickness of the sand-gravel deposits and the $\varrho$-values the highest resistivity being found at the thickest sands and gravels. The contour picture of the equi-resistivity map might indicate the main trend of these deposits to be $\mathrm{SE}-\mathrm{NW}$ and the occurrence to be divided in two subdivisions according to the outlined two resistivity maxima shown on the map.

The interpretation of the electrical drillings is as follows:

File no. 13.2. Veberöd (plate II, fig. 7).

\begin{tabular}{|c|c|c|c|c|c|}
\hline Depth & & $\varrho(\Omega \mathrm{m})$ & Interpretation & Wel & 11 at pt. $120 \mathrm{~m}$ \\
\hline $0-0.7$ & $\mathrm{~m}$ & 137 & $\begin{array}{l}\text { Sand and gravel above } \\
\text { groundwater table }\end{array}$ & $0-9.2 \mathrm{~m}$ & Sand and gravel \\
\hline $0.7-1.45$ & $\mathrm{~m}$ & 45 & Clay & & \\
\hline $1.45-13$ & $\mathrm{~m}$ & 99 & Sand and gravel & $1.5 \mathrm{~m}$ & $\begin{array}{l}\text { Groundwater table } \\
4 / 161952\end{array}$ \\
\hline $13-36$ & $\mathrm{~m}$ & 40 & Clay & $9.2-11.0 \mathrm{~m}$ & $\begin{array}{l}\text { Sand with silt and } \\
\text { clay (?) }\end{array}$ \\
\hline $36-\quad ?$ & $\mathrm{~m}$ & 200 & Pre-Quaternary? & & \\
\hline
\end{tabular}

File no. 13.5. Veberöd (plate II, fig. 8).

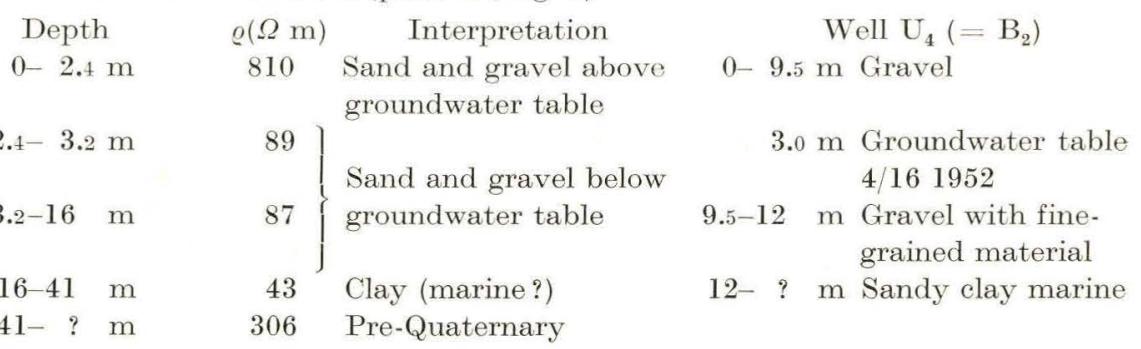

The interpretations are compatible with the adjacent well sections. shown, provided the irregular nature of the bedding is considered.

7. Skive. (Maps fig. 29-30, p. 52-53). Skive waterworks had planned to drill some wells $\mathrm{N}$ and $\mathrm{S}$ of the town. Tertiary clays were expected below the Glacial Drift at depths about $50 \mathrm{~m} \pm$. The Tertiary sequence does not include waterbearing beds, and the Danian limestone found at greater depth carries salt water. Efforts had thus to be concentrated upon 
locating sand or gravel aquifers in the Quaternary, and a trenching programme based on the electrode spacing of $50 \mathrm{~m}$ was therefore put up.

Resistivity was very low in the northern area (fig. 29, p. 52) which was regarded as suggestive of clay deposits. Drilling was accordingly condemned here.

The measurements in the area $\mathrm{S}$ of Skive were much hampered by settlement and vagabondary currents in the subsurface. The trenching values may therefore be much obscured, and the contours indicated on the map (fig. 30, p. 53) should thus only serve as an aid to visualize the variations obtained. They do not lay claim to any degree of certainty.

A well drilled in the area of maximum resistivity values (file no. 55.234) encountered fine melt-water sand from near surface to a depth of about $20 \mathrm{~m}$ and thence sandy melt-water clays until $66 \mathrm{~m}$. A profitable aquifer was located at $66-73,7 \mathrm{~m}$.

It may be the most natural to relate the resistivity maximum with the shallow sand. The applied electrode spacing of $50 \mathrm{~m}$ renders a measurable effect from the lower aquifer very improbable, and the melt-water clay between the upper and lower sands may furthermore act as a bed of high conductivity which may hinder penetration of the current.

An electrical drilling was carried out $\mathrm{E}$ of Skive in order to apply electrode spacings until $250 \mathrm{~m}$. It appeared very difficult to obtain readings with spacings beyond $50 \mathrm{~m}$. The curve shown (plate III, fig. 9) may accordingly be considered rather uncertain. It is believed that the high conductivity of the Tertiary clays may be responsible for the difficult readings of the galvanometer.

8. Lemvig. (Maps. fig. 31-32, p. 54-55). Three trenchings were carried out on 5/20 1953 south of the town in an attempt of locating new drilling sites for water wells. The surveyed area is on the bottom of a valley which is a typical subglacial tunnel valley eroded during the last Quaternary glaciation. The groundwater may be under artesian pressure in the main part of the valley as evidenced by wells drilled in Lemvig town at the waterworks and by springs located on the slopes near the bottom of the valley.

The pre-Pleistocene has not yet been encountered in the wells drilled in the Lemvig area. Tertiary clays are suggested as the underlaying formation at depths about $100 \mathrm{~m}$.

The iso-ohm map fig. $32(\alpha=50 \mathrm{~m})$ reveals the presence of a trend of maximum resistivity extending from the lake to the south. This trend is interpreted as a buried gravel-sand channel, a remnant of the fluvioglacial deposits settled below the ice in the tunnel valley during the Quaternary glaciation.

Wells have not yet been drilled in the maximum, since favourable aquifers were proved by a well located between the waterworks and the 
mapped area near Sögaard. This was a previously recommended location where resistivity mapping was impossible due to settlement and buried steel pipes. The well at Sögaard is on the trend of the maximum.

9. Tåstrup. (Maps fig. 33-35, p. 57-59). In 1932 Hilmar ÖDum could prove the presence of a buried valley in the Danian Bryozoan Limestone at Tåstrup W of Copenhagen by means of the geologic records from drilled wells. The valley may only be about $500 \mathrm{~m}$ wide and its trend may approximately be N-S or NNE-SSW. The surface topography apparently does not disclose significant features of the valley which is filled with Glacial Drift deposits. The elevation of the limestone or deepest Glacial Drift encountered in the wells is shown on map fig. 33.

The narrow Tåstrup valley was chosen for a trial on the problems involved in mapping the limestone bedrock topography. Traverse lines were laid across the valley and connected with intercourse lines, and measurements were carried out with $a=50 \mathrm{~m}$ and $a=100 \mathrm{~m}$. Although a considerable amount of work has already been done the coverage of the area is still rather poor and more work is needed in order to obtain a better control. Some significant interpretative features do, however, appear in this premature stage of the survey which should be briefly outlined, since the features might be of a fundamental character.

On the $50 \mathrm{~m}$ iso-ohm map a resistivity maximum is indicated over the valley whereas a resistivity minimum appears over nearly the same area on the $100 \mathrm{~m}$ map. The geologic interpretation of this combination migth be the following:

With an electrode spacing of $50 \mathrm{~m}$ the current may presumably flow in the glacial deposits above the limestone. It is, however, known from the well logs that the moraine deposits of the Tåstrup valleys include rather sandy beds, which would result in high resistivities, i.e. a local resistivity maximum should be depicted over the valley.

A considerable amount of the Bryozoan Limestone may be involved in the measurements outside the valley in case of the $100 \mathrm{~m}$ mapping, while all the current may practically flow in the moraine deposits in the valley itself. The experience arrived at concerning the resistivities of the limestones with freshwater and the moraine at Herstedöster, Stevns, etc. renders it reasonable to conclude that the apparent resistivities should be high outside the valley where the values may be dominated by the high resistivities of the limestone. The moraine deposits in the valley may certainly have a lower resistivity than the limestone, and a local minimum as realized by the survey should be the result.

10. Rislev. (Maps fig. 36-37, p. 62-63). Hee Andersen and ÖDum mapped an inland occurrence of salt marsh plants in the bog Slagmose at 
Rislev in 1923. Subsequently drilled wells encountered shallow Bryozoan Limestone at about $8 \mathrm{~m}$ depth with salt water of $1.033 \% \mathrm{NaCl}$ in the center of the bog.

The bog was made the object of a resistivity survey which aimed at investigating the salt water occurrence. Trenchings with $a=25 \mathrm{~m} a=$ $50 \mathrm{~m}$ and some electrical drillings were intended. During the course of the survey it turned however out to be impossible to obtain readings with an electrode spacing of $50 \mathrm{~m}$, and it was, therefore, necessary to confine the study to a $25 \mathrm{~m}$ mapping and a single electrical drilling.

The iso-ohm map shows a very simple pattern with the lowermost resistivity found in the center of the bog and the center of the area of the salt marsh plants as outlined by HEE ANDERSEN and ÖDUM in 1923. The resistivity minimum may mainly be related to the salt water which ascends from the deep underground to the surface of the bog. The salt water may thus be the overwhelming factor affecting apparent resistivity in the area according to this interpretation.

The approximately N-S directed trend of the minimum might be considered suggestive of a fracture zone in the limestone with that trend. This hypothesis can of course not be quite rejected. It should, however, be realized that the iso-ohm contours are nearly conform with the contours. of the surface topography around the bog basin (see fig. 36 and 37), which might be indicative of continuous increase of hydrostatic deficit in the low lying area of the bog from the margin of the basin to its center, due to natural drainage of the groundwater and corresponding increase of elevation of the salt water in the subsurface. This hypothesis does not exclude the presence of a fracture zone but it should be emphasized that the trend of the minimum does not necessarily demonstrate the trend of a potential fracture. The electrical drilling was carried out on two lines, one about. $\mathrm{N}-\mathrm{S}$ and the other $\mathrm{E}-\mathrm{W}$. The results were the following:

File no. 216.5. Rislev (plate III, fig. 10).

\begin{tabular}{|c|c|c|c|}
\hline \multirow[b]{2}{*}{ A. $\mathrm{N}-\mathrm{S}$ line } & Depth & $\varrho(\Omega \mathrm{m})$ & Interpretation \\
\hline & $0-0.14 \mathrm{~m}$ & 59 & \multirow{3}{*}{ Peat and sand } \\
\hline \multirow{12}{*}{ B. E-W line } & $0.14-0.3 \mathrm{~m}$ & 39 & \\
\hline & $0.3-0.4 \mathrm{~m}$ & 46 & \\
\hline & $0.4-3.4 \mathrm{~m}$ & 15.2 & Clay \\
\hline & $3.4-11$ & 48.5 & Sand and clay \\
\hline & $11-?$ & 6.6 & Bryozoan Limestone with salt water \\
\hline & $0-0.2 \mathrm{~m}$ & 481 & Pent and sand \\
\hline & $0.2-0.3 \mathrm{~m}$ & $32\}$ & Peat and sand \\
\hline & $0.3-1.8 \mathrm{~m}$ & 13.5 & Clay \\
\hline & $1.8-5.4 \mathrm{~m}$ & $32.3\}$ & clay \\
\hline & $5.4-8.2 \mathrm{~m}$ & 60.0 & Sand and clay \\
\hline & $8.2-26 \mathrm{~m}$ & 21.3 & $\begin{array}{l}\text { Bryozoan Limestone with some salt } \\
\text { water }\end{array}$ \\
\hline & $26-? \mathrm{~m}$ & 5.5 & Bryozoan Limestone with salt water. \\
\hline
\end{tabular}


The resitivity curves are correlatable with the well section shown on plate III, fig. 10 but the salt water does obviously diminish the resistivity of the limestone considerably.

11. Ábenrå. (Maps fig. 38-40, p. 64-67). The town of Åbenrå is forced to increase its pumping capacity in order to meet the growing demand for water. Three test wells were consequently planned in cooperation with the Well Record Department of the Survey in 1953.

The geology of the area concerned is rather unfavourable from the viewpoint of water supply. The thickness of the Glacial drift is about 100 to $120 \mathrm{~m}$ and previous drillings revealed that gravels and sands are very scarce in the moraine deposits which are mixed up and interbedded with sticky, marine, interglacial clays.

The two first wells were completed as dry holes at depths of 95.5 and $92 \mathrm{~m}$ respectively. At this state of affairs it was decided to make a resistivity survey of the areas with the dry holes and of the area where the last test should be drilled.

Resistivity mapping was carried out using trechings with $a=25$ and $a=50 \mathrm{~m}$. The mapping showed very low resistivity values around the dry holes whereas maximum anomalies were indicated in the vicinities. In the third area a maximum of resistivity was located with both spacings, and the maxima nearly covered each other. The high resistivities were interpreted as the effect of gravel and sand deposits at moderate depths, and it was accordingly recommended to drill the next well on the maximum. The following section was encountered.

File no. 160.106. Åbenrå waterworks, Well no. 3, Farversmölle.

$0-2.70 \mathrm{~m}$ Boulder clay and argillaceous sands and gravels

$2.70-10.00 \mathrm{~m}$ Melt-water sands and gravels

$10.00-11.30 \mathrm{~m} \quad$ Boulder clay

$11.30-31.00 \mathrm{~m}$ Melt-water sands and gravels

31.00-37.85 m - — - — with some interbedded clays

37.85-78.00 m Mainly melt-water clay and moraine deposits.

Pumping tests have not yet been made, several of the sand and gravel beds are waterbearing.

12. Ollerup. (Maps fig. 41-42, p. 70-71). The town of Svenborg has planned an extension of its pumping area and several wells have been drilled in a valley system at Ollerup NW of Svendborg. The stratigraphic section may be illustrated by the sequence encountered in test well P9. (location see map fig. 41). 
File no. 164.130. Ollerup. Svendborg Waterworks trial bore P.9.

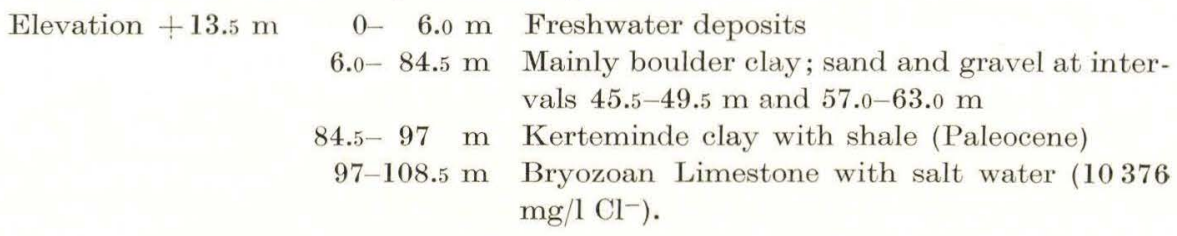

Since the results of the test wells did not offer any possibility of a clear picture of the distribution of the aquifers the Geological Survey was requested to map the resistivity of the valley in which it was intended to locate pumping stations. A trenching programme with $a=50 \mathrm{~m}$ was proposed since the beds below a depth of $50 \mathrm{~m}$ were considered of minor interest partly due to the prevalence of clays, and partly due to the salt water at depth in the Danian Bryozoan Limestone.

The result of the resistivity survey was that the failure wells generally proved to be located in minimum areas while producing wells corresponded to maximum figures of resistivity. The highest values were found on elevated ground $\mathrm{N}$ of the valley, they were interpreted as caused by partly dry sands above the groundwater table.

A drilling was later located in a maximum area in the valley where the groundwater table was suggested near surface. The thickest gravel deposit hitherto found was encountered at the interval $12-30 \mathrm{~m} \mathrm{b.s.} \mathrm{The} \mathrm{yield}$ of the well was, however, to low for the purpose of the waterworks (13.5 $\mathrm{m}^{3} / \mathrm{h}, 4.2 \mathrm{~m}$ depression).

13. Marslev. The dairy needed more water for the manufacturing of milk products than the present wells could produce. A new well did not succeed in finding waterbearing beds in the Pleistocene, which was penetrated at $35 \mathrm{~m}$ and underlied by Paleocene clays. Moreover, the Paleocene beds proved to be salt water bearing from a depth of $46 \mathrm{~m}$. After this failure the proprietor requested the Geological Survey to make a resistivity survey of an area near the dairy.

The area concerned was covered with $50 \mathrm{~m}$ trenchings in order to register the drift resistivities (Maps fig. 43-44, p. 74-75). A broad maximum which extended toward the dairy was defined south of the dairy as displayed by the iso-ohm map fig. 44. Drillings were recommended at an extension of the maximum near the dairy. Four wells have been drilled. Each of the wells proved the presence of sand and gravel beds and the capacities of wells no. 1, 3 and 4 were from 21 to $24 \mathrm{~m}^{3} / \mathrm{h}$ at $3.5 \mathrm{~m}$ depression of the water table. The log of no. 1 was as follows: 
File no. 146.197.a. Marslev Dairy.

0-11.5 m Fine melt-watersand, argillaceous

$11.5-14.5 \mathrm{~m}$ Melt-water clay

14.5-16.5 m Melt-water sand and gravel, waterbearing

16.5-17.0 m Boulder clay, not penetrated.

Water table $1.5 \mathrm{~m}$ below surface.

\section{Concluding Remarks.}

The reported surveys have shown that resistivity methods may be applied to the solution of various geologic problems even in a geologically rather complex area such as the drift area of Denmark. A combined method including both trenching and electrical drilling appears to be most profitable, since the quantitative interpretation of electrical drillings may be very difficult due to the great potential variability of the glacial deposits.

The table p. 78 gives an outline of the approximative resistivities of various Danish formations and deposits experienced during the first year of resistivity measurements in Denmark. 


\section{Litteratur}

(Hvor trykkestedet ikke er nævnt, er det København, D.G.U. = Danmarks Geologiske Undersøgelse).

Andersen, Johs. og Hilmar Ødum. 1930. Om Forekomsten af saltførende Aflejringer i Danmarks Undergrund. D.G.U. II. Række. Nr. 52.

- Knud Hee og Himmar Ødum. 1923. En Salt-Flora i Slagsmose ved Rislev. — Bot. Tidsskr., Bd. 38,5. 57.

Aslyng, H. C. 1952. Characterization of Soils. Roy. Vet. and Agric. Coll. Yearbook 1952 p. 20-56. Copenhagen.

Bertelsen, Ivar. 1940. a. Eksperimentelle Studier over induceret Støj i Telefonenkeltledninger. Aarhus.

— 1940. b. Elektriske Metoder til Undersøgelse af Jordbundens Beskaffenhed. „Elektroteknikeren", Nr. 8.

Berthelsen, Ole. Se Sorgenfret, Th. 1954.

Christensen, Werner. Se Ødum, H. 1936.

Dobrin, M. B. 1952. Introduction to Geophysical Prospecting. New York.

Eklund, J. Se Sundberg, K. 1925.

Elektrisk Malmletning A/S. 1953. PM beträffande Electrical Drilling med ABEM:s Earth Resistivity apparat (upubliceret).

FIsсH, W. 1946. Geoelektrische Untersuchungsmethoden im Dienste der Wasserversorgung. Schweizerischer Ver. v. Gas- u. Wasserfachmännern. Zürich.

- 1953. L'étude du sous-sol par sondage géoélectrique en Suisse et pay voisins C. R. du III. Congr. Intern. de Mécan. des Sols et des Trav. de Fondations Vol. III. p. 145146. Zurich.

Foster, John W. and Merlyn B. Buhle. 1951. An integrated geophysical and geological investigation of aquifers in glacial drift near Champaign-Urbana, Illinois. State Geol. Surv. No. 155. Urbana.

Fritsch, Volker. 1949. Grundzüge der angewandten Geoelektrik. Wien.

Grim, Ralphe. 1953. Clay Mineralogy. New York.

Hansen, Sigurd. 1948. Landskabets geologiske Udformning. Nationalmuseets Skrifter. Ark.-hist. Række, II. (Th. Mathiassen) p. 14-24.

Hallenbach, F. 1953. Geo-electric problems of the hydrology of West-German areas. "Geophysical Prospecting". p. 241-249. Leiden.

Hedström, Helmer. 1928. The Electrical Field from a Point Electrode on the Surface of a Layer Underlain by Another Medium (unpublished manuscript. Houston).

— 1945. Den tillämpade geofysikens metoder. "Kosmos«p. 1-46. Stockholm.

- 1953. = Elektrisk MaLmLetning 1953.

HeIland, C. A. 1951. Geophysical Prospecting. New York.

Hummel, J. N. 1929. a. Der scheinbare spezifische Widerstand. Ztschr. f. Geophysik. V. p. 89-104. Braunschweig.

- 1929. b. Der scheinbare spezifische Widerstand bei vier planparallelen Schichten. Ztschr. f. Geophysik. V. p. 228-238. Braunschweig. 
Hörberg, J. och K.-A. KÄLtstrand. 1953. Geoelektriska metoder för bedömning av grundvattensförekomster. Chalmers Tekniska Högskola. Institutionen för vattenförsörjnings- och avloppsteknik. Publ. 53. 3. Göteborg.

JAKosky, J. J. 1950. Exploration Geophysies. Los Angeles.

Jessen, A. 1945. Kortbladet Sønderborg. D.G.U. I. Række. Nr. 20.

Kelly. Se Leonardon.

Källstrand, K.-A. Se Hörberg, J. 1953.

Køנe, Mogens. 1951. Relations of Vegetation, Soil and Subsoil in Denmark. Dansk Botanisk Arkiv. Vol. 14. p. 1-164.

Leonardon, E. G. and Sherwin F. Kelly. 1928. Some Applications of Potential Methods to Structural Studies. The American Inst. of Mining and Metallurgical Engineers Techn. Publ. No. 115. New York.

Lundberg, H. Se Sundberg, K. 1925.

Minthers, Keld. 1942. Ledeblokke og Landskabsformer i Danmark. D.G.U. II. Række. Nr. 69.

Mrlthers, V. 1908. Kortbladene Faxe og Stevns Klint. D.G.U. I. Række. Nr. 11.

- 1948. Det danske Istidslandskabs Terrænformer og deres Opstaaen. D.G.U. III. Række. Nr. 28.

Moore, R. Woodward. 1952. Geophysical Methods Adapted to Highway Engineering Problems. "Geophysics". p. 505-530. Tulsa.

Nettleton, L. L. 1940. Geophysical Prospecting for Oil. New York.

Nordström, Aluan. 1941. Jämförelse mellan resultaten vid nyligen utförda elektriska malmletningar och efterföljande blottningsarbeten. Norrköping.

Retch, H. und R. v. Zwerger. 1943. Taschenbuch der angewandten Geophysik, Leipzig.

Schlumberger, C. 1930. Etude sur la prospection électrique du soussol. Paris.

Sorgenfrei, Theodor. 1945. Træk af Alnarp Dalens geologiske opbygning. Medd. Dansk. Geol. Foren. Bd. 10. p. 617-630.

- og Ole Berthelsen. 1954. Geologi og Vandboring. D.G.L. III. Række. Nr. 31.

SundberG, K., LundberG, H., and Eklund, J. 1925. Electrical prospecting in Sweden. S.G.U. Ser. C. No. 327. Stockholm.

- 1930. Tektoniska och stratigrafiska undersökningar medelst elektriska metoder. Geol. Fören. i Stockholm Förh. p. 219-246. Stockholm.

Wenner, Frank. 1915. A Method of Measuring Earth Resistivity. Bureau of Standards Scientific Paper No. 258. Washington.

Zwerger, R. v. Se Reich. 1943.

ODum, Hilmar. 1932. En Sænkning i Kalkundergrunden red Taastrup. Hedd. Dansk Geol. Foren. Bd. 8. p. 192-195.

- og Werner Christensen. 1936. Danske Grundvandstyper og deres geologiske Optræden. D.G.U. III. Række. Nr. 26.

- Se Andersen, Johs. 1930.

- Se Andersen, Knud Hee. 1923. 

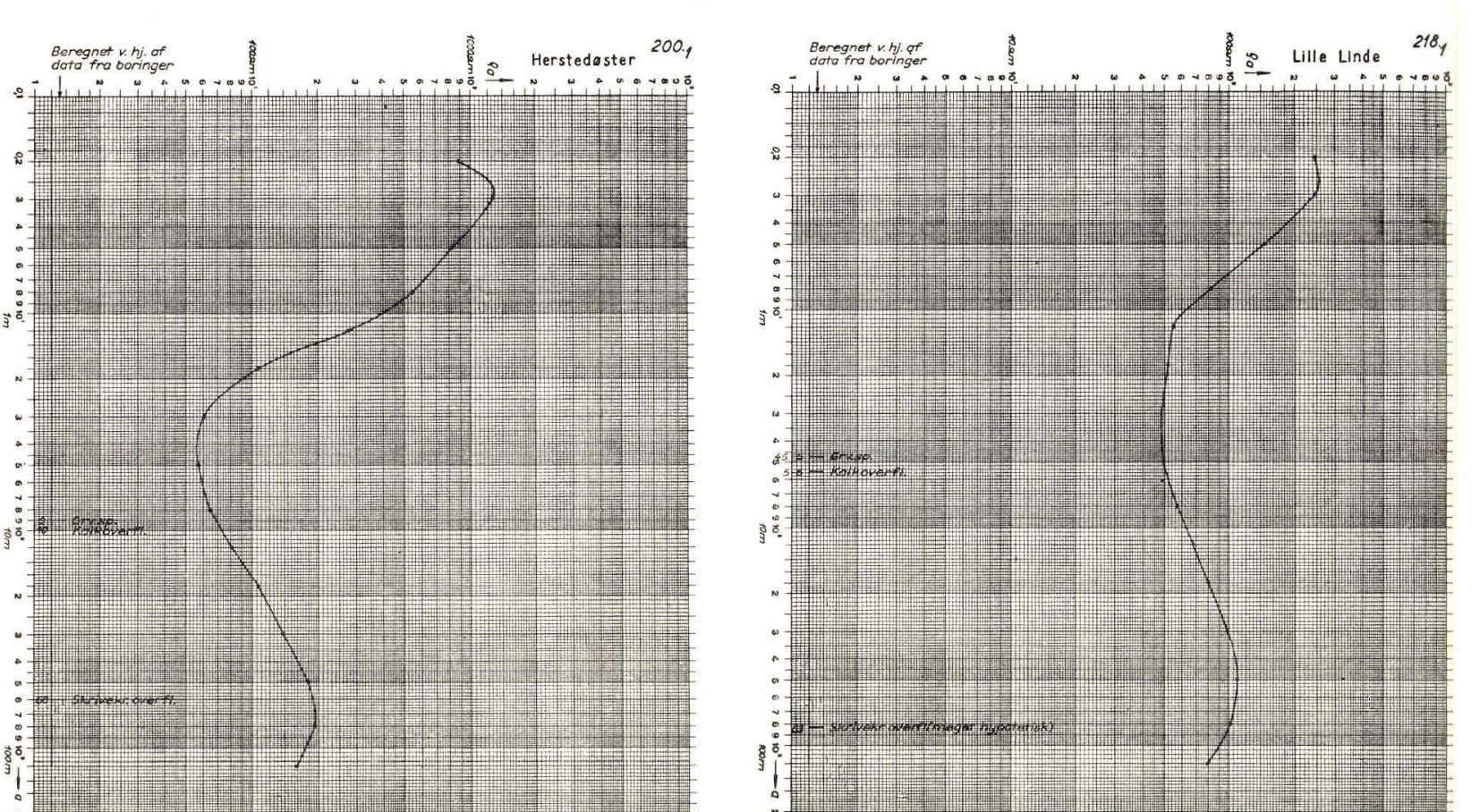

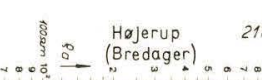

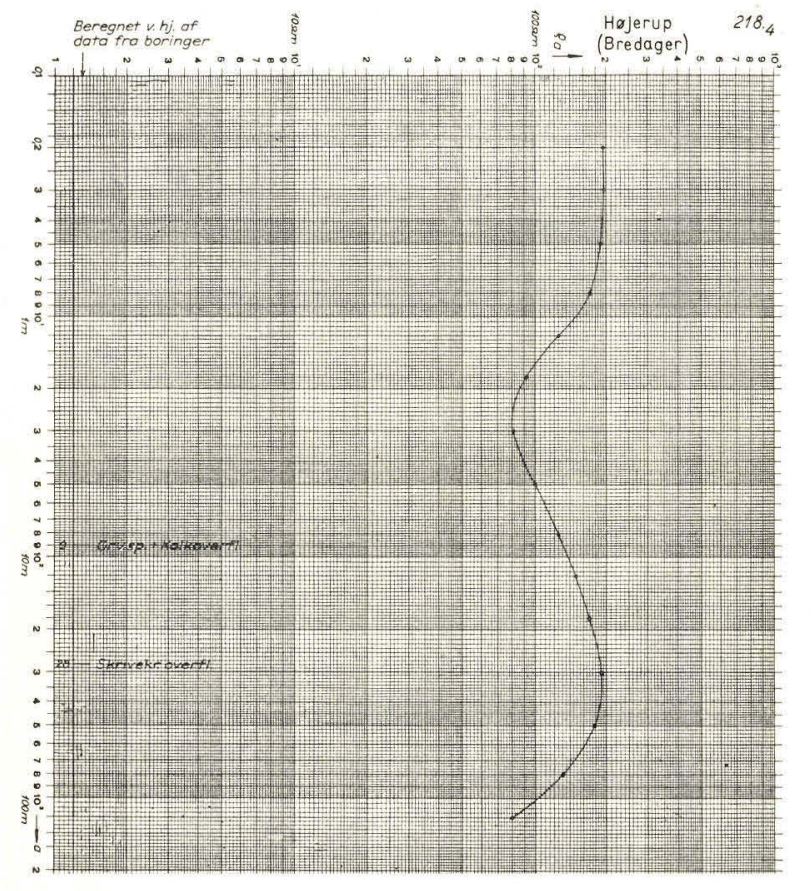

Fig. 5.

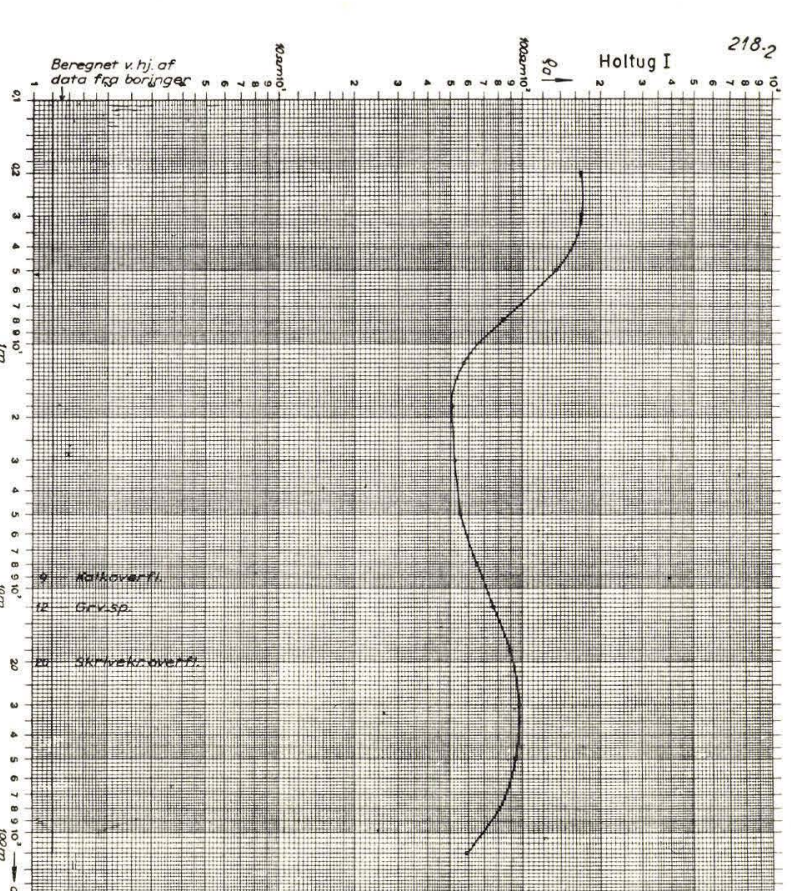

Fic, 3.

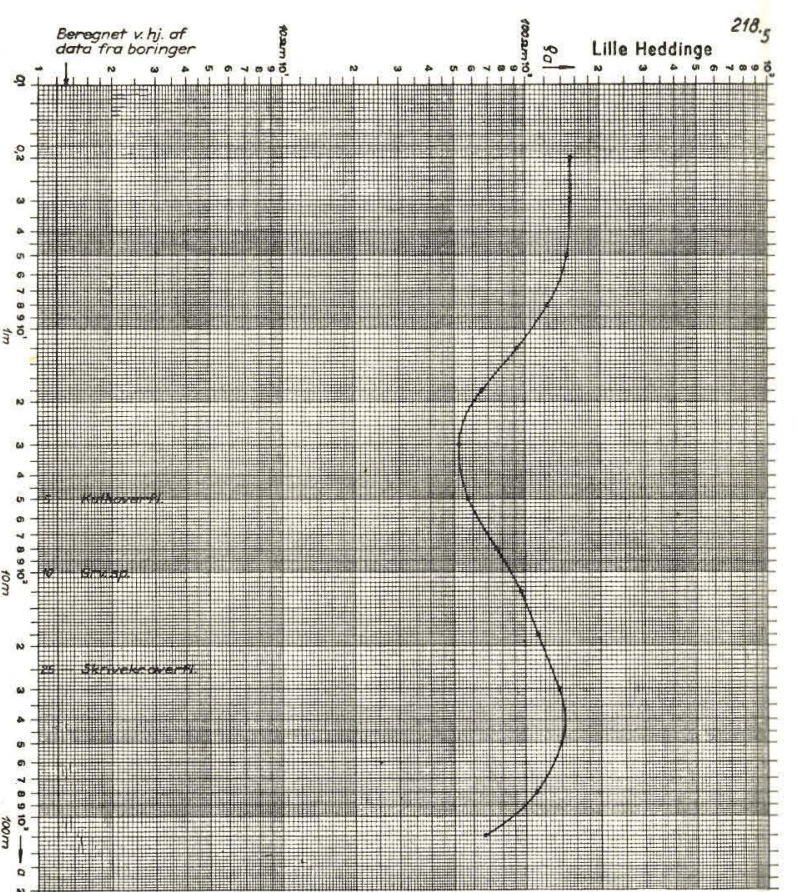

Fig. 6.

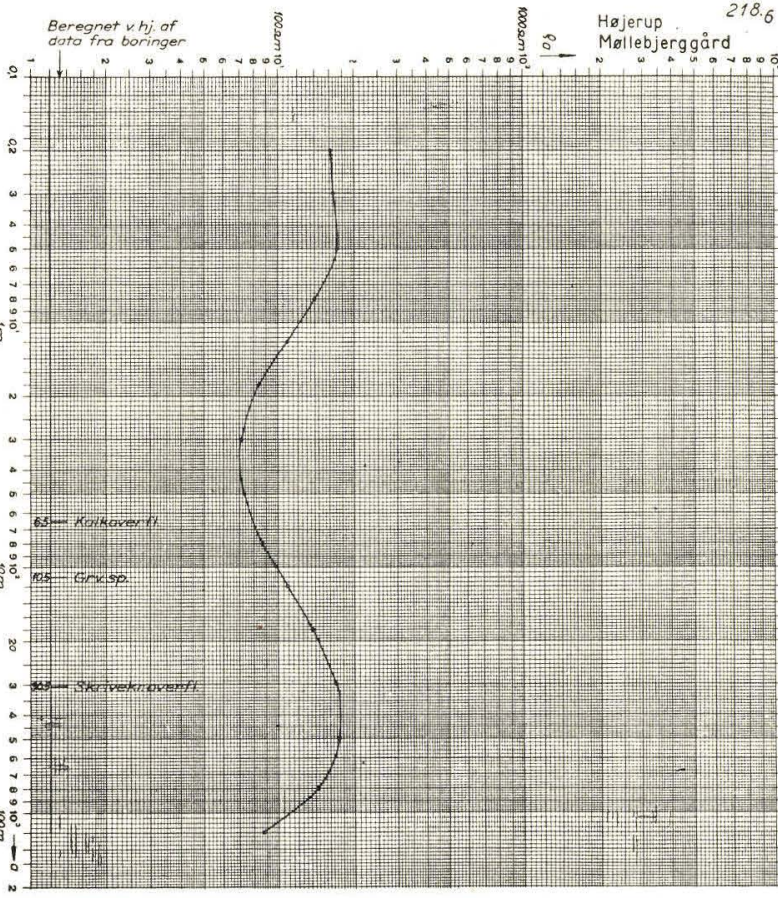

Fig. 7

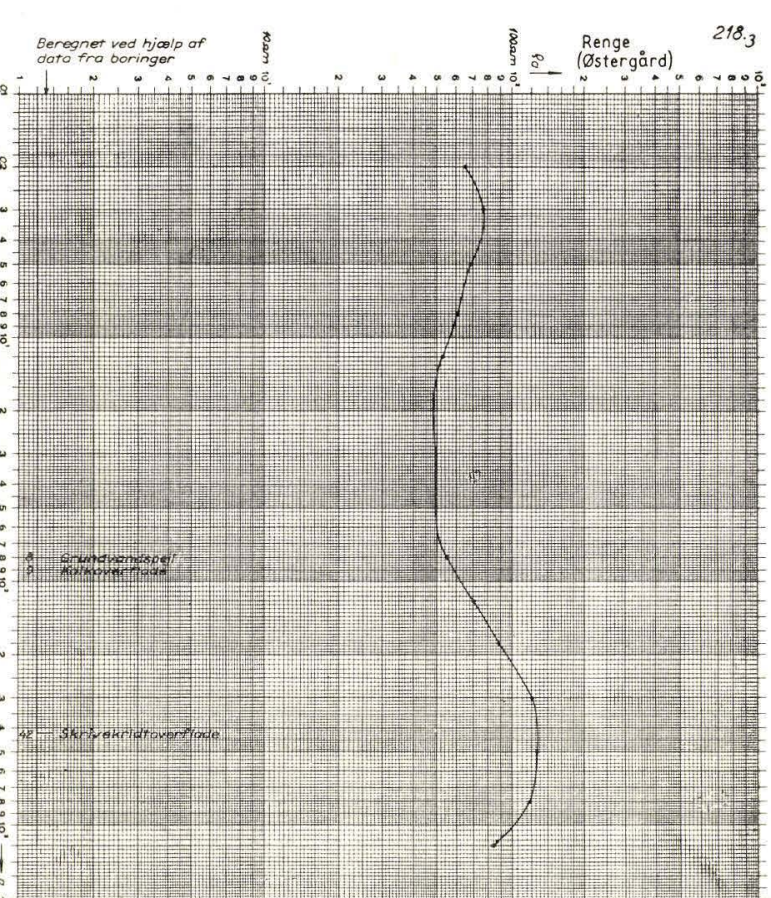

Fig. 4.

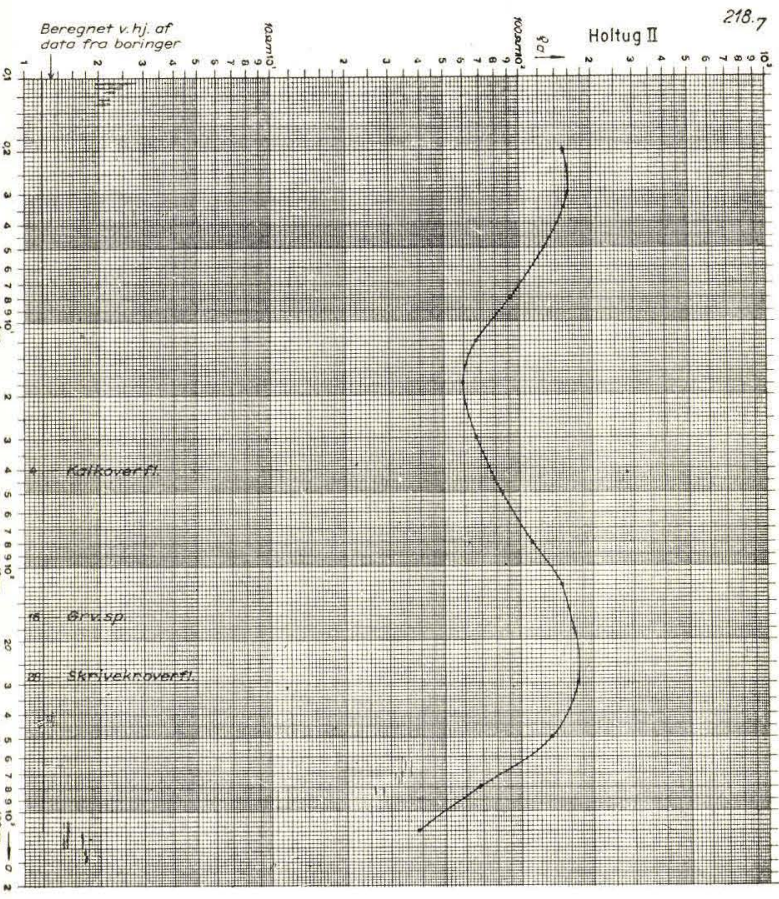

Fig. 8. 

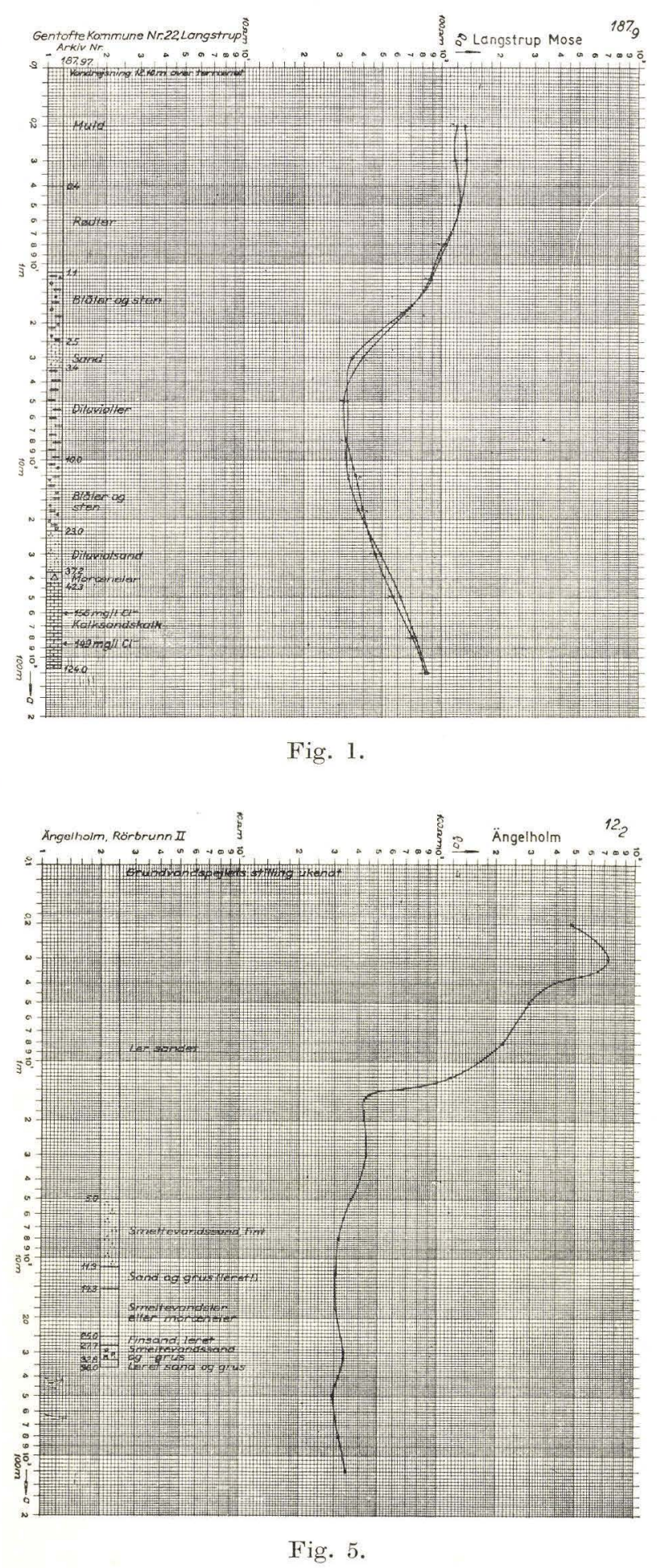

Fig. 5

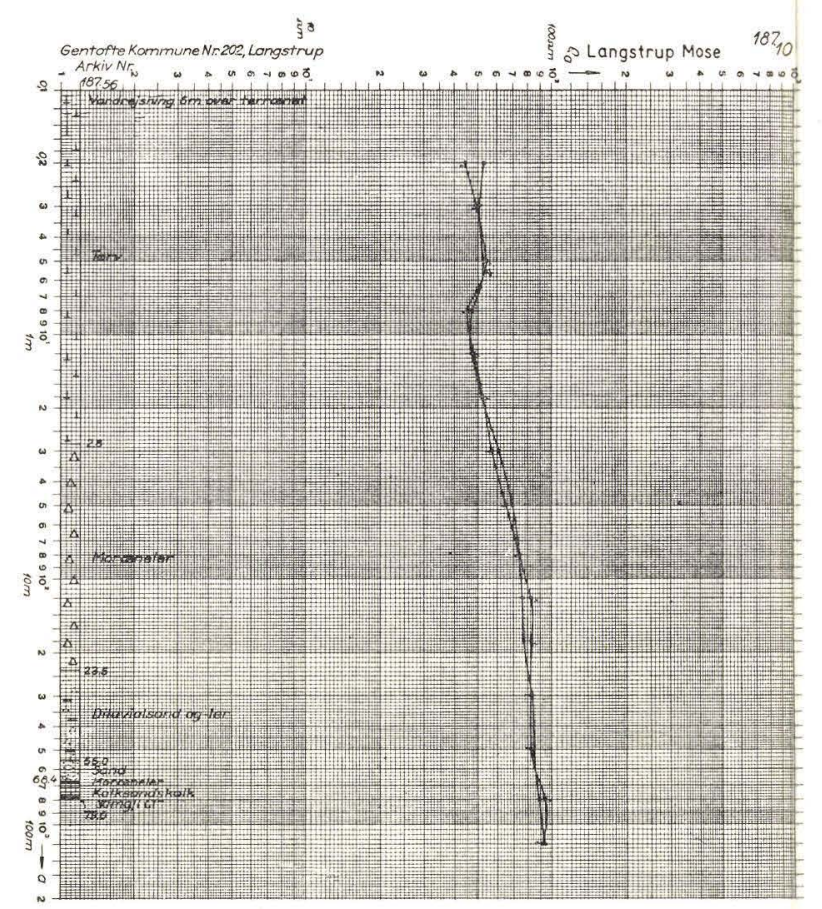
Fig. 2 .

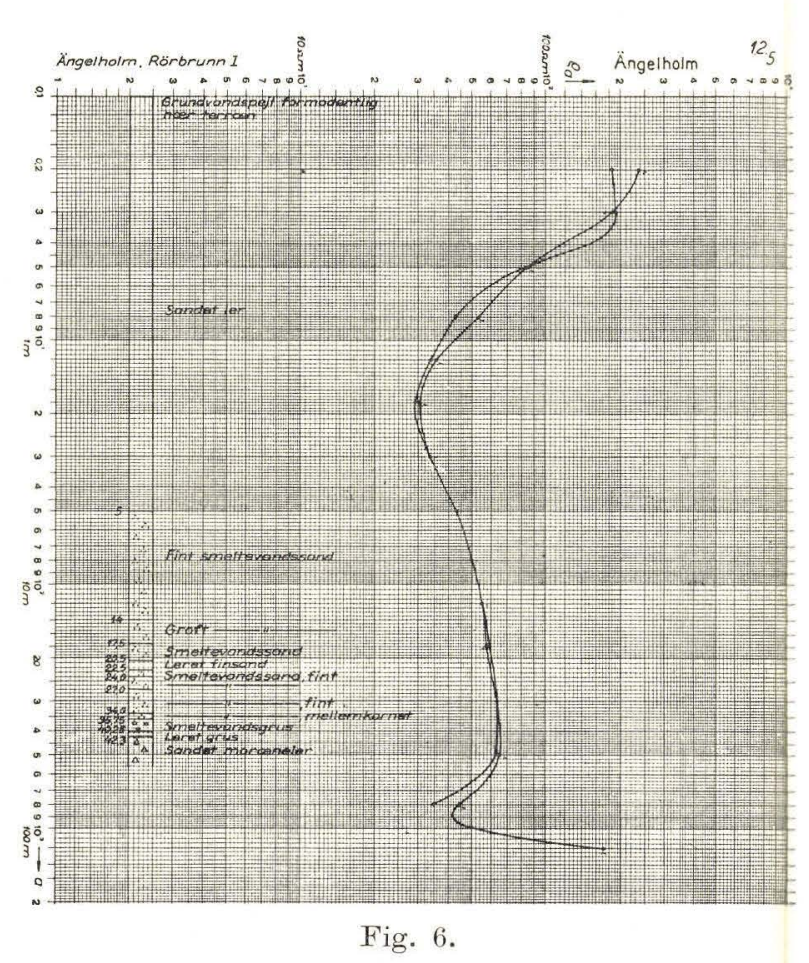

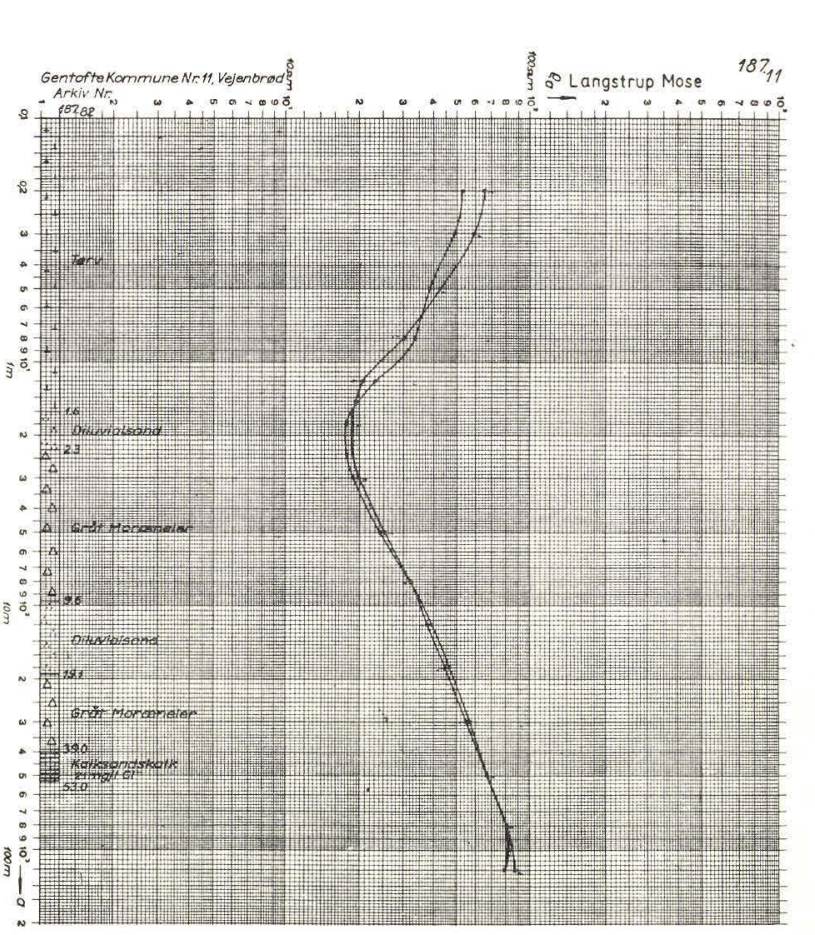

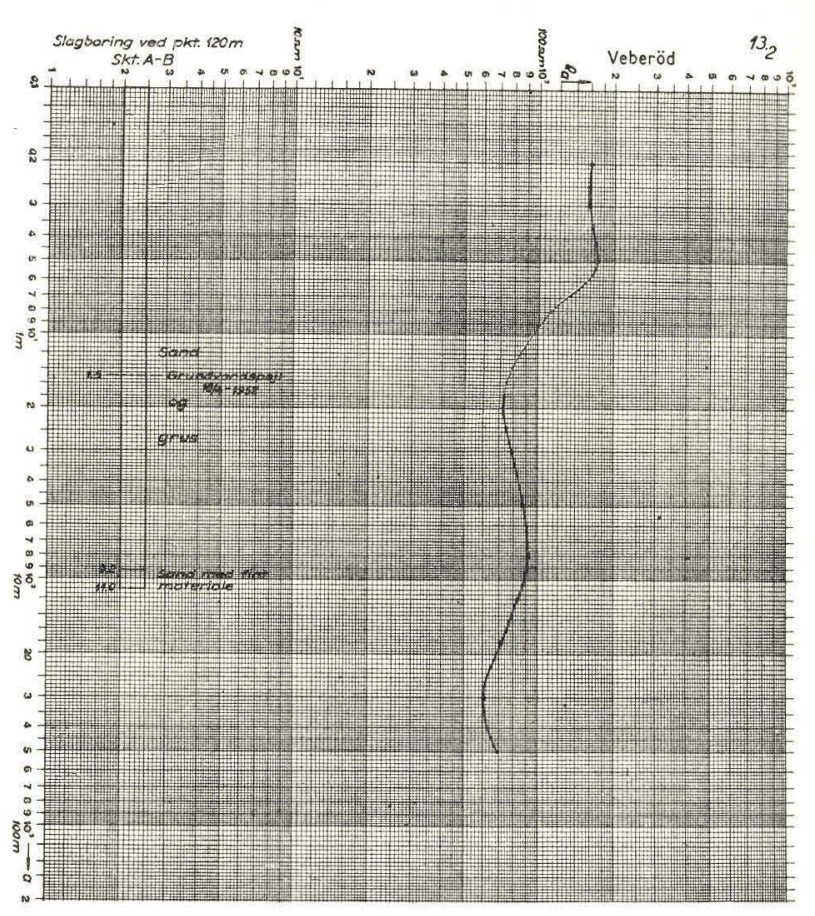

Fig. 7.

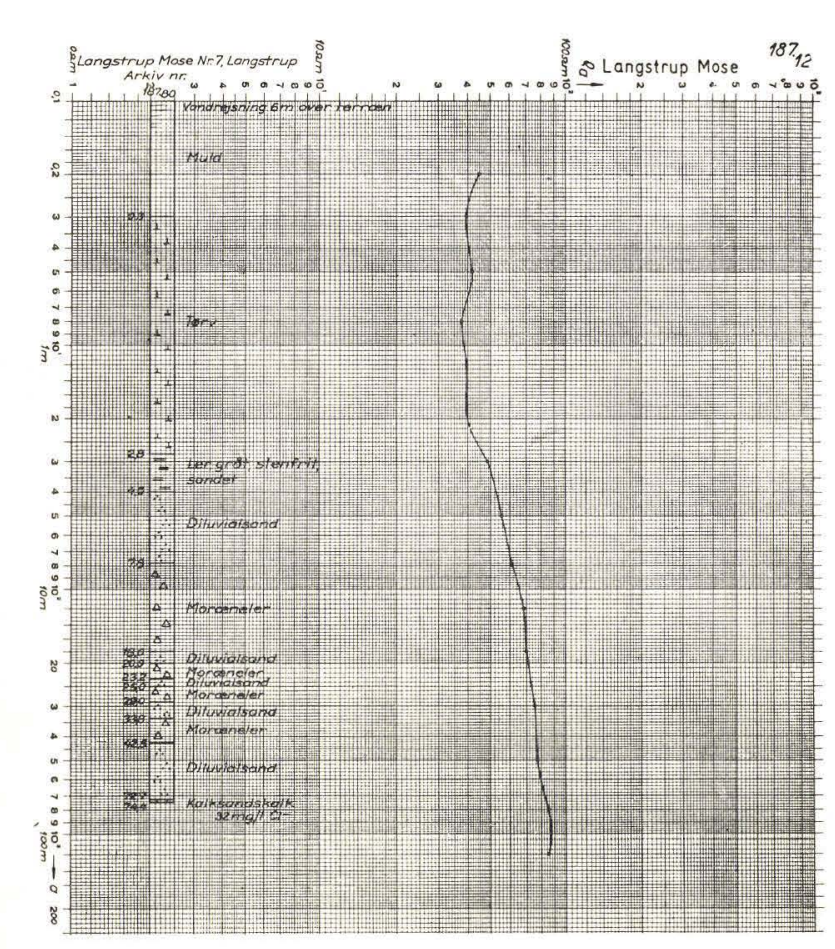
Fig. 4.

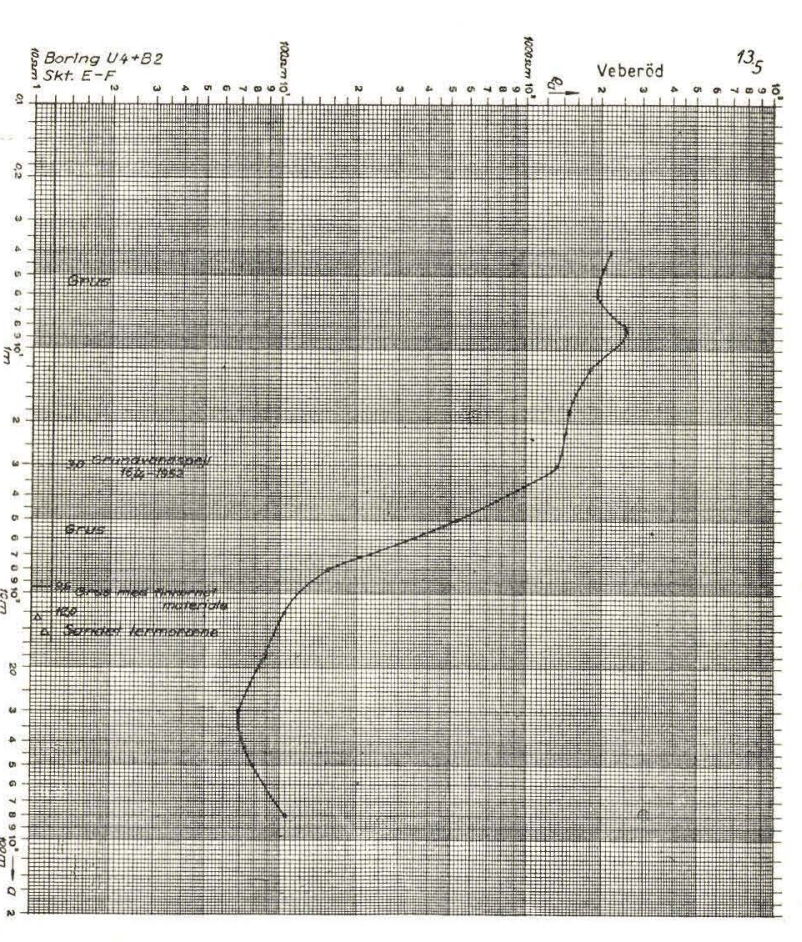

Fig. 8. 



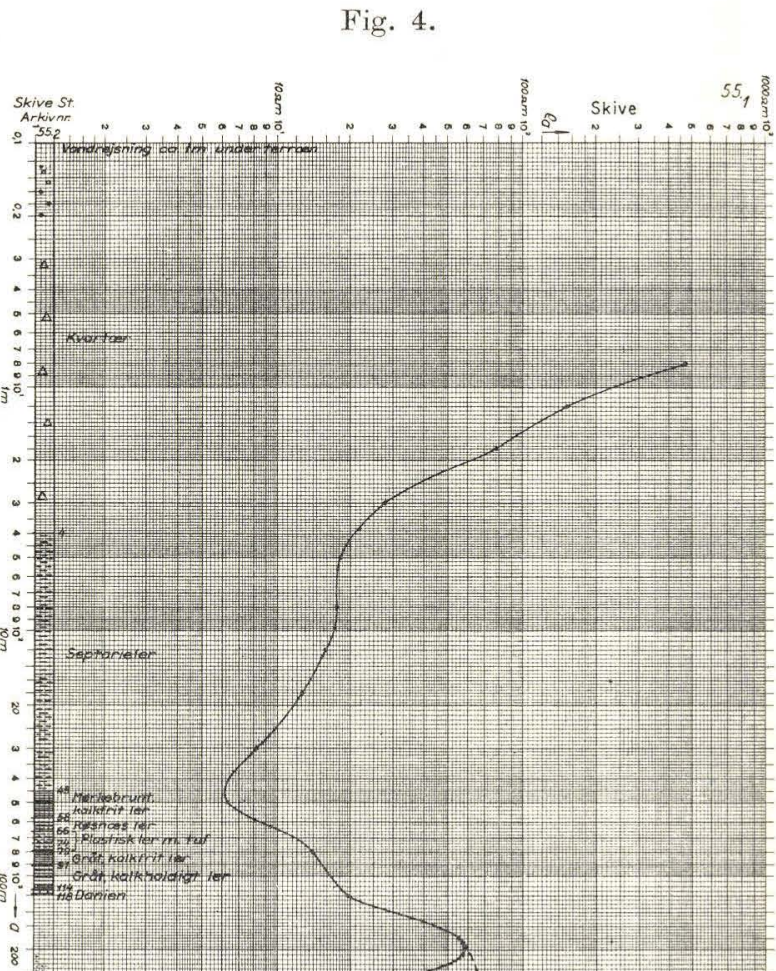

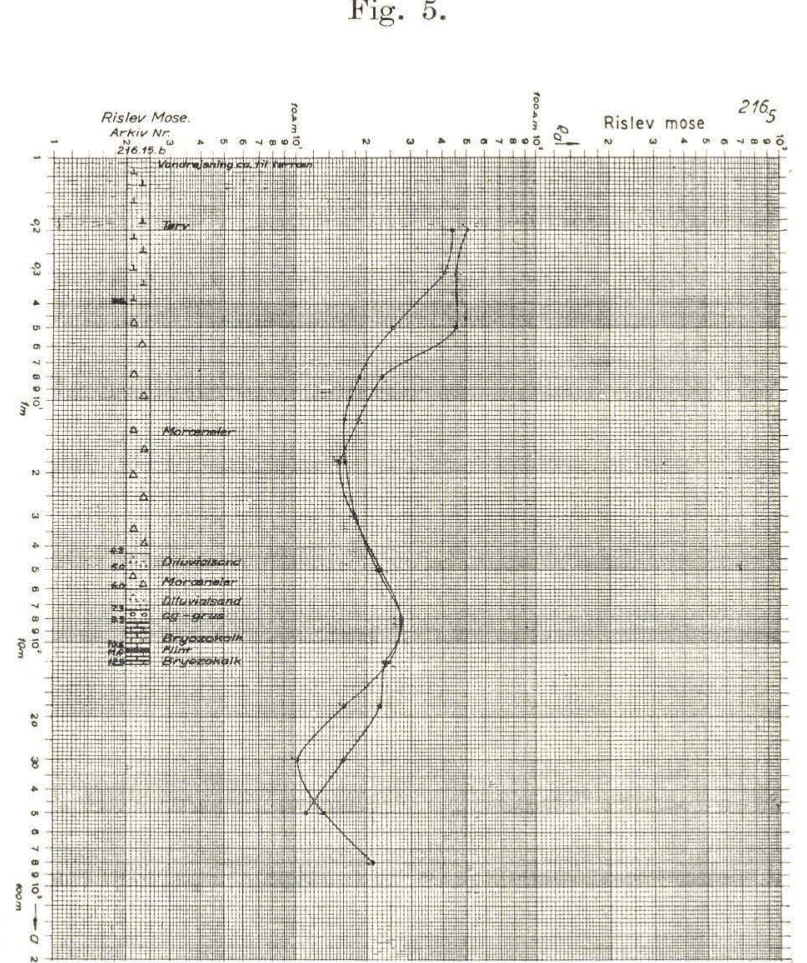

Fig. 10 
FR. BAGGES KGL. HOFBOGTRYKKERI KøBENHAVN

Pris $12 \mathrm{Kr}$. 